\title{
Os quadros de aves tropicais do Castelo de Hoflössnitz na Saxônia e Albert Eckhout (ca. 1610-1666), artista do Brasil Holandês
}

\author{
Dante Martins Teixeira ${ }^{1}$ e
}

\section{Resumo}

Pouco se conhece sobre Albert Eckhout, um dos integrantes da comitiva de Johan Maurits van Nassau-Siegen no Brasil. Entre 1653 e 1663, Eckhout permaneceria a serviço dos príncipes eleitores da Saxônia produzindo obras decorativas e quadros diversos, vários dos quais destruídos em 1945 durante o bombardeio de Dresden. Dos trabalhos que lograram subsistir, o conjunto mais significativo compreende oitenta óleos de aves tropicais que adornam o teto da sala principal do Castelo de Hoflössnitz, palacete erguido entre 1648 e 1650 na localidade de Radebeul. Esses quadros mostram íntima relação com as iconografias elaboradas por Eckhout no Brasil e parecem constituir uma inesperada adição ao projeto inicial do edifício.

\section{Palavras-chaves}

Hoflössnitz, Saxônia, Johann Georg I, Johann Georg II, Albert Eckhout, Johan Maurits van Nassau-Siegen, Brasil Holandês, pintura holandesa, século XVII, aves.

Recebido 17 de fevereiro de 2009

Aprovado 15 de maio de 2009

I Professor adjunto do Departamento de Vertebrados, Museu Nacional da Universidade Federal do Rio de Janeiro (UFRJ). Pós-doutorando do Instituto de Estudos Brasileiros da Universidade de São Paulo (IEB/USP). Bolsista do Conselho Nacional de Desenvolvimento Científico e Tecnológico (CNPq). e-mail dante.teixeira@pq.cnpq.br

2 Nossos agradecimentos a Elly de Vries (Grupo Santander, Brasil) pela generosa cessão de várias imagens de seu acervo privado e a Guido de Werd (Museum Kurhaus Kleve \& Koekkoek-Haus, Cléves) e Espen Waehle (Nationalmuseet, Copenhague), pelo apoio prestado aos trabalhos efetuados. Da mesma forma, gostaríamos de manifestar nosso reconhecimento a Nelson Papavero (Museu de Zoologia/USP) e Maria Carlota Rosa (Faculdade de Letras/UFRJ) pela revisão do texto. Cabe agradecer ain- 


\title{
The paintings of tropical birds in Hoflössnitz, Saxony, and Albert Eckhout (ca. 1610-1666), artist of Dutch Brazil
}

\section{Dante Martins Teixeira}

\begin{abstract}
Very little is known about Albert Eckhout, one of the artists accompanying Johan Maurits van Nassau-Siegen to Brazil. Between 1653 and 1663, Eckhout remained in the Court of Saxony, but a great part of the works produced during this period was destroyed in 1945 during the bombing of Dresden. Among the few surviving canvases attributed to the Dutch artist, the most noticeable are the eighty oils of tropical birds that adorn the ceiling of the main room of Hoflössnitz, a small palace built between 1648 and 1650 in Radebeul. The paintings are obviously based on other works produced by Eckhout during his stay in Brazil, and seem to be an unexpected addition to the initial project of the building.
\end{abstract}

\section{Keywords}

Hoflössnitz, Saxony, Johann Georg I, Johann Georg II, Albert

Eckhout, Johan Maurits van Nassau-Siegen, Dutch Brazil, Dutch painting, 17th century, birds.

da a Paulo Martins Teixeira pela arte final das figuras, bem como a Vera de Figueiredo Barbosa, Antônio Carlos Gomes Lima (Biblioteca do Museu Nacional/UFRJ) e Margareth Elisabeth Cardoso (Livraria Carioca Rio Antigo) pelo auxílio prestado na reunião da bibliografia pertinente e/ou na análise das referências utilizadas. Por fim, cumpre destacar o apoio concedido pelo Conselho Nacional de Desenvolvimento Científico e Tecnológico $(\mathrm{CNPq})$ às pesquisas realizadas pelo autor durante os últimos anos. 


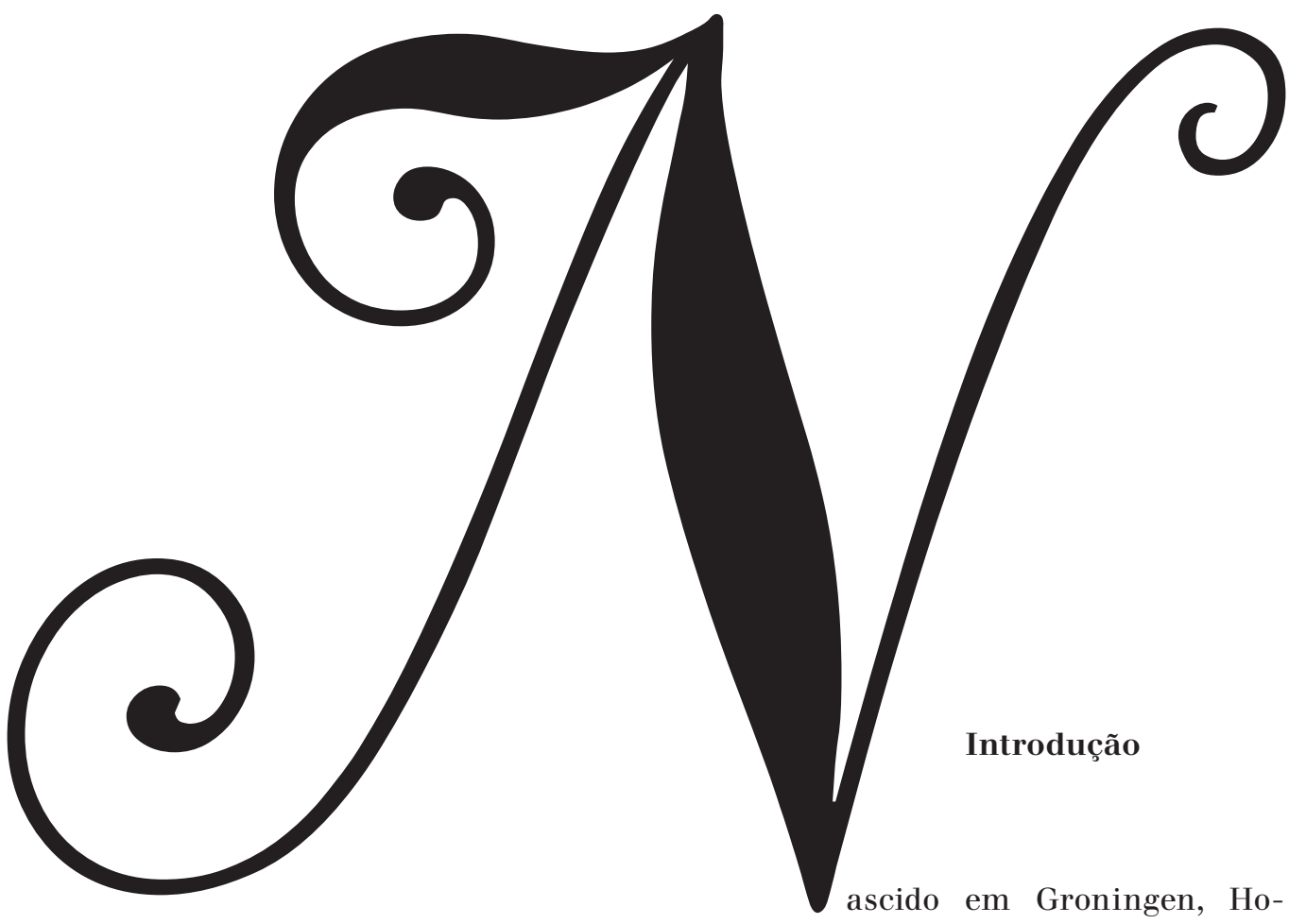

landa, por volta de 1610, Albert Eckhout até hoje constitui um autêntico enigma, não havendo detalhes sobre o início de sua carreira e tampouco maiores informações acerca dos trabalhos executados entre 1637 e 1644 como integrante da comitiva do Conde Johan Maurits van Nassau-Siegen, governador geral das possessões conquistadas pela Companhia das Índias Ocidentais ("Geoctroyeerd Westindische Companie") no nordeste do Brasil ${ }^{3}$. Quanto às atividades desenvolvidas posteriormente na Eu-

3 Albert Eckhout nasceu entre 1607 e 1612 na pequena cidade holandesa de Groningen, realizando seus primeiros estudos artísticos no atelier de seu tio Gheert Roeleffs, sobre o qual tampouco há maiores informações. Forçado a viver por conta própria em Amersfoort e Groningen após seu retorno do Brasil em 1644, Eckhout tornar-se-ia um dos artistas da corte da Saxônia, mudando-se para Dresden em 1653. Embora suas obrigações contratuais incluíssem retratos, paisagens e cenas históricas ou de caça, com certeza sabe-se apenas que pintou dez grandes quadros para o "gabinete de raridades" dos eleitores da Saxônia, todos destruídos em fevereiro de 1945. Dispensado em 19 de junho de 1663 , parece ter retornado de imediato à sua cidade natal na Holanda, conseguindo filiar-se à guilda dos pintores locais já em 1664. Para outros detalhes consultese BESINOVICH, M. Frans Post e Albert Eckhout, pintores holandeses do Brasil e as "tapeçarias das Índias" dos Gobelins. Revista do Serviço do Património Histórico e Artístico Nacional, v. 7, p. 35-56, 1943; BUVELOT, Q. (Ed.). Albert Eckhout: a Dutch artist in Brazil. The Hague: Royal Cabinet of Paintings Mauritshuis, 2004; LEITE, J. R. T. $A$ pintura no Brasil Holandês. Rio de Janeiro: Edições GRD, 1967; MASON, P. Eighty Brazilian birds for Johann Georg. Folk, Journal of the Danish Ethnographic Society, v. 43, p. 103-121, 2001; SCHAEFFER, E. Albert van den Eckhout, ein niederländischer Maler in 
ropa, consta que uma indicação do próprio Nassau levaria Eckhout a se estabelecer na corte da Saxônia, onde permaneceu a serviço dos príncipes eleitores Johann Georg I (1611-1656) e Johann Georg II (1656-1680) por uma década (1653-1663). Nesse período, teria produzido várias obras decorativas e quadros diversos, a maioria dos quais destruída em fevereiro de 1945 durante o bombardeio de Dresden ${ }^{4}$. De volta à cidade natal, Eckhout conseguiria filiar-se à guilda dos pintores locais já em 1664, falecendo no ano seguinte ou logo nos primeiros meses de 1666.

A dispersão do acervo promovida por Nassau e os inevitáveis reveses da sorte fariam com que poucos trabalhos de Albert Eckhout sobrevivessem até os dias de hoje, havendo algumas atribuições discutíveis ou nitidamente equivocadas ${ }^{5}$. Deste ponto de vista, os quadros de aves tropicais

Brasilien. Drei-Monatsschrift de Deutschsprechenden in Südamerika, v. 8, p. 328-333, 1958; SCHAEFFER, E. Albert van den Eckhout, documentarista da Missão Nassau. Habitat: Arquitetura e Artes no Brasil, v. 52, p. 22-28, 1959; SCHAEFFER, E. Albert Eckhout e a pintura colonial brasileira. Dédalo: Revista de Arte e Arqueologia, v. 1, n. 1, p. 47-74, 1965; SOUSA-LEÃO, J. de. Os primeiros pintores do Brasil: problemas e observações. Revista do Instituto Histórico e Geográfico Brasileiro, v. 23o, p. 442-447, jan./mar. 1956; THOMSEN, T. Albert Eckhout ein Niederländischer Maler und sein Gönner Moritz der Brasilianer ein Kulturbild aus dem I7. Jahrhundert. Kopenhagen: Ejnar Munksgaard, 1938; VALLADARES, C. do P.; MELLO FILHO, L. E. de. Albert Eckhout, pintor de Maurício de Nassau no Brasil 1637/1644. Rio de Janeiro: Livroarte, 1981; WHITEHEAD, P. J. P.; BOESEMAN, M. A portrait of Dutch I7th century Brazil: animals, plants and people by the artists of Johan Maurits of Nassau. Amsterdam: North-Holland Publishing, 1989.

Até janeiro de 1945, Dresden havia sofrido apenas dois bombardeios pouco significativos em pequenas indústrias localizadas nos subúrbios. Nos dias 13 e 14 de fevereiro desse mesmo ano, entretanto, a capital da Saxônia seria alvo de 650.000 bombas incendiárias lançadas por 311 Fortalezas Voadoras da Usaf e 796 Lancaster da RAF, os quais sobrevoaram a cidade em três ondas sucessivas, tendo como único alvo o velho centro histórico. Nada menos de $\mathbf{1 3 5 . 0 0 0}$ vítimas sucumbiriam sob o impacto de mais de 1.50o toneladas de altos explosivos e 1.200 toneladas de artefatos incendiários, o que transformaria esse bombardeio no mais cruento ataque aéreo desfechado na Europa ao longo de toda a Segunda Grande Guerra. Em termos culturais e históricos, as perdas ultrapassariam todos os limites imagináveis, pois os verdadeiros "furacões de fogo" criados pelos bombardeios maciços consumiram cerca de 400.000 títulos pertencentes ao acervo da Sächsische Landesbibliothek e um elevadíssimo número de monumentos e obras de arte, inclusive dez quadros pintados por Albert Eckhout entre 1653 e 1663 . Com a derrocada de Dresden, as duas potências ocidentais pretendiam sobretudo promover uma demonstração de força dentro do incipiente jogo da Guerra Fria, tendo escolhido os quarteirões medievais e barrocos ricos em madeirame exatamente para testar de forma cabal suas teorias acerca da capacidade destrutiva de um bombardeio de saturação. Maiores detalhes sobre o assunto e impressionantes fotografias de Dresden destruída estão disponíveis em CARTIER, R. La Seconde Guerre Mondiale. Paris: Librairie Larrousse, 1965; DEAR, I. C. B.; FOOT, M. R. D. (Ed.). The Oxford companion to the Second World War. Oxford: Oxford University Press, 1995; IRVING, D. The destruction of Dresden. London: William Kimber, 1963 e VERRIER, A. The bomber offensive. London: B. T. Batsford, 1968.

5 Vide TEIXEIRA, D. M. As duas tartarugas: uma pintura atribuída a Albert Eckhout (ca. 1610-1666), artista do Brasil Holandês. Publicações avulsas do Museu Nacional, v. 112, p. 1-24, 2006. 
encontrados no teto da sala principal do Castelo de Hoflössnitz ${ }^{6}$, arredores de Dresden, adquirem considerável importância por constituir um dos raros conjuntos pictóricos sem dúvida alguma associados ao artista holandês. No entanto, tal vínculo passaria despercebido durante muito tempo, pois folhetos oferecidos aos visitantes do "Weinbaumuseum der Stadt", instalado em Hoflössnitz, mencionam essas pinturas como relacionadas a seres imaginários das fábulas europeias pelo menos até a década de 1960.

Seguindo projeto de Ezechiel Eckhart, arquiteto de Johann Georg I, o Castelo de Hoflössnitz seria erguido em dois anos (1648-1650) na localidade de Radebeul, pequeno vilarejo situado cerca de $12 \mathrm{~km}$ a noroeste de Dresden. Trata-se de um prédio com três pavimentos de fachada discreta (fig. 1 e 2) no qual os príncipes eleitores da Saxônia podiam desfrutar da caça e dos momentos bucólicos sempre tão valorizados pelo imaginário citadino ${ }^{7}$, enquanto saboreavam o produto das vindimas locais. Esta pretensa rusticidade, contudo, ocultava a magnificência do salão principal e dos dois cômodos laterais existentes no primeiro andar, ambientes suntuosos decorados com várias pinturas, murais, painéis e entalhes (fig. 3). Considerando as diversas publicações disponíveis sobre Hoflössnitz ${ }^{8}$, cabe tecer apenas breves comentários acerca desse salão

6 A exemplo de vários autores, decidimos adotar "Castelo de Hoflössnitz" como tradução de Weinbergschlösschen Hoflössnitz, pois tal expressão não encontra exato equivalente no nosso idioma. Ainda que "castelo" carregue um nítido sentido militar para a maioria dos brasileiros, cumpre notar que a palavra $S c h l o \beta$ - e seus derivados - pode ser aplicada a edifícios tão distintos entre si como palácios, mansões e castelos propriamente ditos. No entanto, Hoflössnitz não teria quaisquer fins defensivos, consistindo apenas de uma casa de campo apalacetada mais próxima de certas quintas portuguesas ou do tradicional château francês.

7 Vide SCHAMA, S. Landscape and memory. New York: Vintage Books, 1995.

8 Seja pela suntuosidade ou pelo exotismo, o fato é que o Weinbergschlösschen de Hoflössnitz foi objeto de diversas publicações, entre as quais destacamos BESCHORNER, H. Die Hoflössnitz bei Dresden. Dresdner Geschichtsbläter, v. 13, n. 1, p. 209-226, 1904; BESCHORNER, H. Die Hoflössnitz bei Dresden. Dresdner Geschichtsbläter, v. 13, n. 2, p. 239-247, 1904; BESCHORNER, H. Die Hoflössnitz bei Dresden. Geschichtliche Wanderfahrten, v. 10, p. 1-40, 1931; BLUMHAGEN, M.; MAGIRIUS, H. (Org.) 6oo Jahre Hoflößnitz:Historische Weingutanlage. Dresden: Michel Sandstein, 2oor; HAUSWALD, G. Forschungsreise nach Brasilien. Wiederentdeckung eines Sächsischen Naturforschers. Sächsische Heimatbläter, v. 7, n. 5, p. 271-274, 1961; HAUSWALD, G. Guirapotiapirangaiuparaba. Sächsische Heimatbläter, v. 7, n. 7, p. 410-415, 1961b; HEBEDA, J. Weinbergschlösschen Hoflössnitz. Leipizig: VEB E. A. Seemann, Buch- und Kunstverlag, 1980; LÖFFLER, F. Die Monumentalmalerei des Barock in Dresden. In: KREY, H. (Ed.), Jahrbuch zur Pflege der Künste. Dresden: Wolfgang Jess Verlag, 1956, p. 5-23; MAGIRIUS, H. Die Hoflössnitz. Berlim: Deutscher Kunstverlag, 1996; MASON, P. Eighty Brazilian birds for Johann Georg. Folk, Journal of the Danish Ethnographic Society, v. 43, p. 103-121, 2001; SCHAEFFER, E. Bilder brasilianischer Vögel in einem deutschen Jagdschlößchen. Staden Jahrbuch, v. 14, p. 175-183, 1966; SCHAEFFER, E. Albert Eckhout, um pintor holandês no Brasil (1637-1644). Anais do Museu Histórico Nacional, v. 2o, p. 17-84, 1968; SCHAEFFER, E. Pássaros do Brasil: Albert Eckhout. Rio de Janeiro: Agir, 
principal, aqui entendido como único espaço a apresentar obras de arte relacionadas ao Brasil Holandês, mais especificamente um conjunto de oitenta óleos sobre tela sem data ou assinatura que figuram aves registradas pelos artistas de Nassau no Novo Mundo.

Assumindo o formato de um quadrado com $10 \mathrm{~m}$ de lado, este salão atinge cerca de 3,5 m de pé direito e possui duas janelas retangulares voltadas para o norte e quatro para o sul. Situado na fachada setentrional, seu estreito portal de entrada conecta-se a uma escada em caracol disposta no interior de uma curiosa torre externa octogonal (fig. 4). $\mathrm{O}$ piso é composto por lajotas quadrangulares de pedra e as paredes ocidental e oriental abrigam grandes lareiras, estruturas secundadas pelas portas dos aposentos destinados ao eleitor e sua consorte, cada qual dividido em uma saleta e um dormitório (fig. 5). Cobrindo completamente o teto do salão, os oitenta quadros de aves brasileiras ocupam os espaços mais ou menos retangulares criados por sete longas traves longitudinais e 72 peças curtas transversais, ambas muito ornamentadas. Para efeito da presente análise, todas as pinturas foram numeradas, de forma arbitrária, de norte para sul e de leste para oeste (fig. 6, tab. 1). A esmagadora maioria dessas telas apresenta sua borda superior voltada para oeste, orientação invertida apenas nos casos dos óleos 41 e 75.

\section{Os quadros de Hoflössnitz}

Dos oitenta quadros de Hoflössnitz, 74 são retangulares e oscilam em torno dos $90 \times 75 \mathrm{~cm}$, enquanto os seis restantes apresentam diferentes desenhos e tamanhos, adaptando-se aos recortes criados pelo umbral da entrada ou por ambas as lareiras (fig. 7 a 26). De fato, as duas obras adjacentes ao pórtico formam um pentágono irregular de $90 \times 65 \mathrm{~cm}$ (pinturas 31 e 41), enquanto aquelas vizinhas às chaminés assumem o feitio de um retângulo com 411 x $68 \mathrm{~cm}$ (pinturas 6 e 76) ou de um hexágono irregular com 50 × $68 \mathrm{~cm}$ (pinturas 5 e 75). Conforme destacam vários autores ${ }^{9}$, os trabalhos em foco não previam a adição de vistosas

1970; TEIXEIRA, D. M. (Org.) Brasil Holandês: documentos da biblioteca universitária de Leiden, o Thierbuch e a Autobiografia de Zacharias Wagener e os quadros do Weinbergschlösschen de Hoflössnitz. Rio de Janeiro: Editora Index, 1997 e THOMSEN, T. Albert Eckhout ein Niederländischer Maler und sein Gönner Moritz der Brasilianer ein Kulturbild aus dem I7. Jahrhundert. Kopenhagen: Ejnar Munksgaard, 1938. Sobre a vida e obra de Ezechiel Eckhart, consulte-se BESCHORNER, H. Ezechiel Eckhart, der Erdbauer der Hoflössnitz. Dresdner Geschichtsbläter, v. 18, n. 2, p. 30-35, 1909.

9 Por exemplo WHITEHEAD, P. J. P., BOESEMAN, M. A portrait of Dutch I7th century Brazil: animals, plants and people by the artists of Johan Maurits of Nassau. Amsterdam: North-Holland Publishing, 1989. 
molduras marmoreadas providas de um friso dourado mediano, arremate que terminaria por cobrir uma margem de cerca de $3 \mathrm{~cm}$, por vezes ocultando partes significativas dos elementos retratados ${ }^{10}$.

Em geral, os nomes das espécies representadas foram escritos em grandes capitulares romanas traçadas em vermelho na metade superior da tela, havendo um único caso do uso de minúsculas no canto inferior direito (pintura 51). Entretanto, cinco desses óleos permaneceram anônimos, enquanto em dois outros um único vocábulo foi aplicado a mais de uma espécie (tab. 1) ${ }^{11}$. A exemplo das aves retratadas (vide adiante), os termos em questão apresentam notável coincidência com os vocábulos encontrados nas Icones Volatilium e nos Libri Principis - iconografias elaboradas durante o chamado Período Mauriciano da ocupação holandesa no Brasil (1637-1644) ${ }^{12}$ - refletindo a peculiar grafia fonética tantas vezes

10 Em 1991, grande parte dessas pinturas havia sido retirada de seus nichos para reparos, a primeira iniciativa do gênero levada a cabo desde a última restauração ocorrida em 1912. Tendo os originais das Icones Volatilium e dos Libri Principis como referência, esse trabalhoso processo permitiu que se comprovasse a aparente inexistência de maiores retoques ou pentimentos, pois os lugares afetados trouxeram à luz apenas a tela recoberta por uma tinta-base avermelhada. Embora confirmem que os quadros já ocupavam sua posição atual pelo menos desde o começo do século, os comentários de H. Beschorner levantam algumas dúvidas quanto aos nomes observados nos dias de hoje, pois esse autor assinala "jacamaçirî" ao invés de "jacamiri” para a pintura 52, não registra a presença da palavra “qúijúba” na pintura 58 etc., discrepâncias que parecem constituir meros deslizes do autor. Vide BESCHORNER, H. Die Hoflössnitz bei Dresden. Dresdner Geschichtsbläter, v. 13, n. 1, p. 209-226, 1904; BESCHORNER, H. Die Hoflössnitz bei Dresden. Dresdner Geschichtsbläter, v. 13, n. 2, p. 239-247, 1904; BESCHORNER, H. Die Hoflössnitz bei Dresden. Geschichtliche Wanderfahrten, v. 1o, p. 1-40, 1931; WHITEHEAD, P. J. P., BOESEMAN, M. A portrait of Dutch 17 th century Brazil: animals, plants and people by the artists of Johan Maurits of Nassau. Amsterdam: North-Holland Publishing, 1989.

11 As telas anônimas de Hoflössnitz compreendem as pinturas 5, 9, 21, zo e 70, enquanto que nas pinturas 45 e 76, um único vocábulo (respectivamente "pecacú" e "guirá") terminou sendo conferido a duas aves distintas.

12 Em 1644, desavenças com a Companhia das Índias Ocidentais culminariam no retorno de Johan Maurits van Nassau-Siegen à Holanda após sete anos de permanência no Brasil. Entre os tesouros levados para a Europa nessa ocasião, destacava-se um expressivo conjunto de quadros, pinturas avulsas, estudos e desenhos executados por Albert Eckhout, Frans Post e outros membros da corte flamenga no Recife. Em 1652, fração substantiva desse acervo passaria às mãos de Friedrich Wilhelm, eleitor de Brandemburgo, em troca de certas dignidades nobiliárquicas e uma grande soma empregada na compra do Castelo de Freudenberg nos arredores de Cléves. Além de móveis, utensílios e despojos de animais do Brasil, o pecúlio enviado a Berlim compreendia aquarelas e desenhos já encadernados em dois tomos, os chamados Libri Principis ou "Manuais", assim como numerosas pinturas sobre papel e crayons avulsos. Entre 166o e 1664, essas ilustrações seriam organizadas por Christian Mentzel, médico particular de Friedrich Wilhelm, nos quatro fólios do Theatrum rerum naturalium Brasiliae, nomeados como Icones Animalium, Icones Volatilium, Icones Aquatilium e Icones Vegetabilium. Para maiores detalhes, vide THOMSEN, T. Albert 
utilizada pelos comandados de Nassau no registro dos nomes populares de animais e plantas do Novo Mundo. O tupi é o principal idioma utilizado, havendo apenas dois presumíveis substantivos africanos relativos a espécies trazidas do outro lado do Atlântico para a corte do Recife ${ }^{13}$.

O provável auxílio prestado por tais documentos, porém, não evitaria certas incongruências, pois existem telas anônimas baseadas em aves de nome conhecido e vice-versa ${ }^{14}$, além de quadros com denominações distintas daquelas observadas nas imagens originais (vide tab. 2). Apesar de formas abreviadas ou pequenas diferenças de escrita constituírem a maioria dos casos (pinturas 1, 31, 50, 52 e 76), não faltam designações assaz discrepantes (pinturas 20, 32, 33, 55 e 67), inclusive algumas de inequívoca origem tupi não observadas em qualquer outra fonte do período, detalhe indicativo da participação de alguém familiarizado com a fauna e a linguagem dos habitantes do Novo Mundo (vide adiante) ${ }^{15}$.

Eckhout ein Niederländischer Maler und sein Gönner Moritz der Brasilianer ein Kulturbild aus dem I7. Jahrhundert. Kopenhagen: Ejnar Munksgaard, 1938; WHITEHEAD, P. J. P. The clupeoid fishes of the Guianas. Bulletin of the British Museum (Natural History) Zoology, Suppl. 5, p. 1-227, 1973; WHITEHEAD, P. J. P.; BOESEMAN, M. A portrait of Dutch I7th century Brazil: animals, plants and people by the artists of Johan Maurits of Nassau. Amsterdam: North-Holland Publishing, 1989.

13 Referimo-nos aos quadros do "quelele" (pintura 24) e do "quingúoanqúi" (pintura 62), que figuram respectivamente uma pintada (Guttera pucherani) e um flamingo (Phoenicopterus ruber roseus). Segundo o testemunho dos naturalistas do Brasil Holandês, "quetele" seria um nome local atribuído à primeira espécie em Serra Leoa, enquanto "quingúoanqúi” parece pertencer a algum idioma de Angola. Vide MARCGR AVE, G. Historia rervm natvralium Brasiliae libri octo ... In: Historia Naturalis Brasiliae. Lvgdv[nvm] Batavorvm \& Amstelodami: Fransiscum Hackium \& Lud[ovicum] Elizevirium, 1648, p. 1-283; PISO, G. De Indiae Utriusque re naturali et medica Libri quatuordecim, Quorum contenta pagina sequens exhibet. Amstelaedami: Ludovicum et Danielem Elzevirios, 1658; PISO, G. De Indiae Utriusque re naturali et medica Libri quatuordecim, Quorum contenta pagina sequens exhibet. Amstelaedami: Ludovicum et Danielem Elzevirios, 1658 e TEIXEIRA, D. M. O mito da natureza intocada: as aves do Brasil Holandês (1624-1654) como exemplo para a história recente da fauna do Novo Mundo. Tese (Doutorado em Zoologia) - Programa de Pós-Graduação em Zoologia, Museu Nacional, Universidade Federal do Rio de Janeiro, Rio de Janeiro, 1999.

14. Duas telas anônimas de Hoflössnitz (pinturas 5 e 21) foram baseadas em aves de nome conhecido segundo os respectivos modelos das Icones Volatilium e dos Libri Principis, enquanto em outras duas (pinturas 7 e 45) ocorre precisamente o contrário (vide tab. 2). Nesse último caso, entretanto, foram empregadas designações tupis que - grosso modo - correspondem às aves retratadas, detalhe indicativo da existência de certa familiaridade com a fauna e a linguagem dos habitantes do Brasil.

15 Os cinco quadros de Hoflössnitz que apresentam nomes bastante diversos daqueles encontrados nas ilustrações equivalentes dos Libri Principis ou das Icones Volatilium levantam aspectos interessantes e contraditórios. Com efeito, embora reproduza a aquarela do "íbijaû" (Nyctibius grandis) dos Libri Principis (volume II, p. 97), a pintura 32 recebeu a denominação de "cabúré", detalhe curioso pelo fato de muitos leigos tomarem os urutaus (Nyctibiidae) como um tipo de coruja (Strigidae). O conhecimento sobre a avifauna sul-americana implícito nessa relação, entretanto, contrasta com o 
Podendo conter de um a três exemplares, sempre localizados em primeiro plano, essas oitenta composições retratam 88 aves pertencentes a 77 espécies distintas, total bastante surpreendente por atingir 44,51\% dos 173 representantes desse grupo zoológico assinalados no material do Brasil Holandês examinado até o momento (tab. 1) ${ }^{16}$. Enquanto algumas poucas foram dispostas de asas abertas em pleno vôo, a maioria permanece pousada em galhos, penhascos ou em algum tipo de elevação. Além de toscos e por vezes quase grosseiros, os elementos da paisagem de fundo não guardam maiores relações com as espécies figuradas, embora a pintura 50 constitua notável exceção por ilustrar duas aves brasileiras - um pica-pau (Phloeoceastes melanoleucos) e um corrupião (Icterus icterus) - sobre um cacto do Novo Mundo, provavelmente um mandacaru (Cereus jamacaru) (fig. 19), ao passo que a vegetação das telas 42 e 55 inclui desenhos difusos recordando palmeiras tropicais (fig. 17, 20 e 27). Em menor grau, esse princípio também se aplica aos próprios voláteis, amiúde retratados com pernas demasiado longas e colorido pouco fiel, além de bicos e pés desproporcionais ou deformados. Não raro, esses equívocos mostraram-se capazes de inspirar comentários peculiares, havendo mesmo sugestões de o pintor ter utilizado o "corpo de um pássaro, completando-o com o bico e os pés de outro"17. Como os quadros de Hoflössnitz estão calcados em imagens de melhor qualidade produzidas durante a ocupação holandesa do Brasil, parece mais razoável atribuir tais desacertos a limitações técnicas do artista e sua pouca experiência com os motivos escolhidos (vide adiante). Não surpreende, portanto, que certas particularidades dos originais terminassem sendo ampliadas

"guirácocó" e o "pongobi” conferidos ao tucano (Ramphastos vitellinus ariel) e ao araçari (Pteroglossus aracari) retratados nas pinturas 55 e 67, pois os Ramphastidae constituem um grupo muito característico exclusivo do Novo Mundo e ambos os nomes, na verdade, dizem respeito a pássaros de pequeno porte com aspecto muito distinto (vide

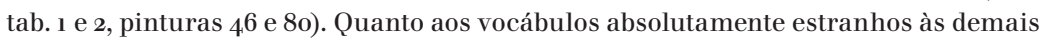
fontes do Brasil Holandês, cabe mencionar que o "jaguaçatî" (Nystalus maculatus) dos Libri Principis (v. I, p. 111) aparece como "cúauna" na pintura 2o, enquanto o "çurucuâ" (Trogon collaris), figurado nessa mesma iconografia (vol. II, p. 204), surge como "guirapotiapirangaiuparaba" na pintura 33 (vide tab. 1 e 2). O primeiro pode ser entendido como uma mera variante de "guiráuna" ("ave negra") aplicada de forma indevida, mas o segundo pode ser traduzido como "ave multicor de peito vermelho" e constitui um termo muito complexo e pouco comum da língua tupi.

16 Vide TEIXEIRA, D. M. O mito da natureza intocada: as aves do Brasil Holandês (16241654) como exemplo para a história recente da fauna do Novo Mundo. Tese (Doutorado em Zoologia) - Programa de Pós-Graduação em Zoologia, Museu Nacional, Universidade Federal do Rio de Janeiro, Rio de Janeiro, 1999. Esse total de 77 espécies distintas seria alcançado apenas se considerarmos que a pintura 70 retrata uma juruva (Momotus momota) e que a ave não identificada da pintura 38 tampouco corresponde a qualquer uma das outras espécies figuradas nos quadros de Hoflössnitz.

17 Cf. SCHAEFFER, E. Pássaros do Brasil: Albert Eckhout. Rio de Janeiro: Agir, 1970. 
ou simplesmente repetidas sem qualquer alteração nos óleos de Hoflössnitz $^{18}$. Sequer as diferenças de porte seriam respeitadas, havendo casos de aves maiores e menores reproduzidas lado a lado sem grandes diferenças de tamanho ${ }^{19}$.

Ao contrário do pretendido por determinadas fontes, as paisagens de fundo dos quadros de Hoflössnitz não guardam qualquer semelhança com o Brasil e tampouco podem ser atribuídas apenas à Saxônia ${ }^{20}$, amiúde retratando um ambiente fictício inspirado na natureza europeia onde se alternam montanhas, penhascos, colinas, bosques, campos, quedas d'água e diferentes edifícios vistos ao longe, além de rios e lagos cortados ou não por embarcações, pontes e ilhas verdejantes. Entretanto, algumas telas incluem motivos pouco comuns, tais como gado pastando (pintura 57), ruínas tomadas pela vegetação (pintura 68), cavernas (pintura 73) e até mesmo patíbulos com postes, forcas e corpos pendentes (pinturas 62 e 72), enquanto outras fogem da monotonia usual ao apresentar um fundo de penhascos escarpados (e. g. pintura 18), agrestes descampados com escassa ou nenhuma vegetação ( $e$. g. pinturas 8 e 14), colunas de uma varanda (pintura 61) ou apenas o céu nublado (e. g. pintura 77). Certas composições sugerem uma relação mais estreita entre a paisagem e o animal, como seria o caso de aves aquáticas retratadas próximas a uma ribeira (e. $g$. pinturas 17 e 53) ou na vizinhança de um braço de mar com desembarcadouros e navios (e. g. pintura 1) (fig. 27). Mesmo

18 Tal como ocorre nas pinturas produzidas no Brasil pelos artistas de Nassau, os quadros de Hoflössnitz tampouco respeitaram a verdadeira posição dos dedos nos pés de aves zigodáctilas ou heterodáctilas. Além disso, as peculiaridades de certos indivíduos - por exemplo um joão-bobo (Nystalus maculatus) desprovido de cauda - foram reproduzidas sem maiores alterações (pintura 2o), enquanto outros tiveram detalhes da plumagem ampliados, equívoco capaz de converter a anhuma (Anhima cornuta) com vestígios de castanho nas coberteiras superiores retratada nos Libri Principis (vol. I, p. 170) em um exemplar de asas totalmente castanhas (pintura 56). Compare com TEIXEIRA, D. M. (Org.). Brasil Holandês: Miscellanea Cleyeri, Libri Principis \& Theatrum rerum naturalium Brasiliae. Rio de Janeiro: Editora Index, 1995 .

19 A pintura 76 constitui um bom exemplo nesse sentido ao quase igualar um bem-tevi-de-bico-chato (Megarhynchus pitangua) de $20 \mathrm{~cm}$ de comprimento e um gaviãopreto (Buteogallus urubitinga) de $63 \mathrm{~cm}$.

20 Causa grande surpresa o fato de certos autores identificarem nesses quadros paisagens brasileiras atribuíveis a Franz Post, pois sequer parece razoável que tais composições ilustrem apenas a Saxônia como pretendem alguns. De fato, algumas dessas pinturas parecem ter como fundo uma vasta extensão de água cortada ou não por navios (e. $g$. pintura 1), formando uma grosseira marinha absolutamente estranha a uma região localizada no interior da Alemanha. Vide SCHAEFFER, E. Pássaros do Brasil: Albert Eckhout. Rio de Janeiro: Agir, 197o; WHITEHEAD, P. J. P.; BOESEMAN, M. A portrait of Dutch I7th century Brazil: animals, plants and people by the artists of Johan Maurits of Nassau. Amsterdam: North-Holland Publishing, 1989 . 
não sendo casual, tal coincidência não basta para comprovar uma maior intimidade do artista com a natureza do Novo Mundo, pois os táxons envolvidos poderiam ter sido facilmente associados a elementos bem conhecidos da fauna europeia, isso sem contar o fato de pés palmeados e outros detalhes anatômicos talvez não terem passado despercebidos. Na maioria das vezes, porém, não existe qualquer afinidade entre a espécie representada e o fundo escolhido, situação perceptível mesmo no caso de telas dedicadas a aves pernaltas fáceis de identificar em termos de seus hábitos paludícolas (e. g. pinturas 11 e 19). Por fim, os óleos de Hoflössnitz tanto podem mostrar um céu claro quanto muito carregado, havendo doze obras onde é possível observar de três a onze silhuetas de aves em pleno vôo, em geral esboços muito grosseiros traçados sem maiores pretensões ${ }^{21}$ (fig. 27).

\section{As aves retratadas}

Mesmo um exame superficial basta para demonstrar a estreita relação dos quadros de Hoflössnitz com as figuras das Icones Volatilium e dos Libri Principis, identidade assaz evidente em termos dos nomes empregados, das espécies ornitológicas envolvidas e das próprias pinturas - meras cópias pouco fiéis das ilustrações originais ${ }^{22}$. Origem de 44 das 88 aves existentes $(50,00 \%)^{23}$, as imagens das Icones Volatilium surgem como a principal fonte de referência, ao passo que as aquarelas pertencentes ao primeiro tomo dos Libri Principis teriam servido de modelo para 25 reproduções $(28,39 \%)^{24}$ e as do segundo volume para nove

21 Ao todo, seriam setenta silhuetas pertencentes às pinturas $3,8,10,22,23,46,51,57$, 59, 62, 73 e 74. A maioria está constituída por traços quase infantis e sem qualquer pretensão descritiva, embora duas das sete presentes na pintura 22 e duas das cinco observadas na pintura 23 figurem aves de bico comprido e longas pernas que recordam a espécie representada em primeiro plano. Conforme mencionado, o número dessas figuras por quadro varia das três encontradas na pintura 8 às onze da pintura 73, ainda que a maioria passe facilmente despercebida.

22 Vide TEIXEIRA, D. M. (Org.). Brasil Holandês: documentos da biblioteca universitária de Leiden, o Thierbuch e a Autobiografia de Zacharias Wagener e os quadros do Weinbergschlösschen de Hoflössnitz. Rio de Janeiro: Editora Index, 1997; TEIXEIRA, D. M. O mito da natureza intocada: as aves do Brasil Holandês (1624-1654) como exemplo para a história recente da fauna do Novo Mundo. Tese (Doutorado em Zoologia) - Programa de Pós-Graduação em Zoologia, Museu Nacional, Universidade Federal do Rio de Janeiro, Rio de Janeiro, 1999.

23 As cópias das Icones Volatilium estão nas pinturas 1, 4, 6, 7, 9, 11, 12, 14, 16, 18, 19, 21, 22, $25,29,31,34,35,36,37,3^{8}, 39,42,43,46,48,51,5^{2}, 55,57,58,60,61,62,64,66,71,72,73$, $75,77,78$ e 79 (vide tab. 2 ).

24. Essas cópias podem ser observadas nas pinturas 3, 4, 8, 10, 13, 15, 17, 20, 23, 28, 30, 41, $47,5^{0}, 5^{2}, 53,54,56,5^{8}, 59,65,67,69$ e 80 (vide tab. 2 ). 
$(10,23 \%)^{25}$. Além disso, cinco aves $(5,69 \%)$ tanto poderiam estar baseadas nas Icones Volatilium quanto no primeiro volume dos Libri Principis (fig. 28 e 29 , tab. 2$)^{26}$.

Dos cinco elementos restantes (5,69\%), o primeiro (pintura 70) talvez seja versão muito pouco feliz das juruvas (Momotus momota) figuradas nas Icones Volatilium ou nos Libri Principis, mas os quatro outros parecem não estar relacionados a qualquer iconografia do Brasil Holandês conhecida até o momento (tab. 2). De fato, o material examinado não mostra corrupiões (Icterus icterus) em pleno vôo (pintura 68), guarás (Eudocimus ruber) com a plumagem escarlate típica de exemplares selvagens (pintura 49), araracangas (Ara macao; pintura 2) ou pintadas africanas (Guttera pucherani; pintura 24) (fig. 7, 12, 19, 23 e 24). No entanto, como esta última foi registrada por Marcgrave sob o nome de "quetele"27, parece razoável supor que o óleo de Hoflössnitz constitua a única cópia disponível de uma ilustração hoje desaparecida, hipótese contrária a certas previsões ${ }^{28}$. Ao menos em parte, o mesmo raciocínio poderia ser aplicado aos quadros do corrupião e do guará (vide adiante), enquanto a imagem de uma araracanga pode ser entendida como um simples equívoco envolvendo a arara-vemelha (Ara chloroptera) assinalada pelos naturalistas e pintores de Nassau no nordeste do Brasil. Na verdade, essas duas araras de plumagem escarlate seriam confundidas por mais de trezentos anos, equívoco desfeito com a descrição de Ara chloroptera como forma independente em meados do século XIX ${ }^{29}$. No entanto, a araracanga parece ter sido a melhor conhecida das duas espécies, conquistando lugar de destaque nos textos de diversos naturalistas dos séculos XVI e XVII ${ }^{30}$, além de marcar presença em trabalhos de artistas como Lucas Cranach (1472-1553), Jan Brueghel (1568-1625), Roe-

25 Essas cópias podem ser observadas nas pinturas 26, 27, 32, 33, 44, 45, 50 e 76 (vide tab. 2).

26 Tratam-se das aves representadas nas pinturas 5, 40, 63, 74 e 76 (vide tab. 2).

27 Vide MARCGRAVE, G. Historia rervm natvralium Brasiliae libri octo ... In: Historia Naturalis Brasiliae. Lvgdv[nvm] Batavorvm \& Amstelodami: Fransiscum Hackium \& Lud[ovicum] Elizevirium, 1648, p. 1-283.

28 Compare com WHITEHEAD, P. J. P.; BOESEMAN, M. A portrait of Dutch I7th century Brazil: animals, plants and people by the artists of Johan Maurits of Nassau. Amsterdam: North-Holland Publishing, 1989.

29 Vide GRAY, G. R. List of the specimens of birds in the collection of the British Museum. London: Trustees of the British Museum. Part III, Section II: Psittacidae, 1859.

zo Vide ALDROVANDI, U. Ornithologiae hoc est de avibus historia libri XII. Bononiae: Franciscis Senensem, 1599-16oz; GESNER, K. Historiae Historiae Animalium Liber III qui est de Auium natura. Tigvri: Christoph. Froschovervm, 1555; HERNANDEZ, F. Rervm medicarvm Novae Hispaniae thesavrvs sev Plantarvm animalivm mineralivm mexicanorum. Rome: Typographia Vitalis Mascardi, 1651 e WILLUGHBY, F. Ornithologiae libri tres: In quibus Aves omnes hactenus cognitae in methodus naturis suis convenientem redactae accuratè describuntur. Londini: Impensis Joannis Martyn, 1676. 
landt Savery (1576-1639) e Balthasar van der Ast (1593-1657) ${ }^{31}$. A julgar pelas notícias contidas no Naturalien-Buch de Jacob Wilhelm Griebe ${ }^{32}$, a araracanga e a arara-canindé (Ara ararauna) obtinham bom preço na Saxônia seiscentista, sendo disputadas pela aristocracia local como luxuosos animais de estimação.

Apesar de todas as limitações herdadas dos originais do Brasil Holandês, os óleos de Hoflössnitz reúnem um elenco peculiar selecionado conforme algum parâmetro obscuro capaz de descartar representantes tão notáveis como os beija-flores (Trochilidae), aves muito admiradas na Europa seiscentista ${ }^{33}$. Embora distinguir categorias arbitrárias nesse conjunto mostre-se uma tarefa difícil, talvez não seja gratuito o fato de 29 das 77 espécies (37,66\%) corresponderem às chamadas “aves aquáticas”, ou que haja sete imagens distintas de gaviões (9,09\%), rapineiras de inegável valor simbólico no imaginário cristão e considerável interesse para uma nobreza alemã praticante da cetraria ${ }^{34}$. Da mesma forma, os cinco papagaios, periquitos e afins figurados $(6,49 \%)$ poderiam refletir a grande estima dedicada aos psitácidas, aqui entendidos como xerimbabos destinados a alcançar preços nada desprezíveis no último quartel do século XVII ${ }^{35}$. Esse fascínio por aves exóticas ou de colorido berrante também poderia

31 Vide JACKSON, C. E. Dictionary of bird artists of the world. Woodbridge: Antique Collectors' Club, 1999; SICK, H. Brasilianischer Ara 1502/o3. In: Europa gemalt. Journal für Ornithologie, v. 125, n. 4, p. 479-481, 1984; TEIXEIRA, D. M.; PAPAVERO, N. Os animais do descobrimento: a fauna brasileira mencionada nos documentos relativos à viagem de Pedro Álvares Cabral (1500-1501). Publicações avulsas do Museu Nacional, v. 111, p. 1-133, 2006. In: TEIXEIRA, D. M. (Org.). Brasil Holandês: a Coleção Niedenthal, o Animaux et oiseaux e o Nauralien-Buch de Jacob Wilhelm Griebe. Rio de Janeiro: Editora Index, 1998. Vide L'ECLUSE, C. de. Exoticorum Libri Decem: Quibus Animalium, Plantarum, Aromatum, aliorumque peregrinorum Fructuum historiae describuntur. Antuerpiae: Ex Officina Plantiniana Raphelengii, 1605; MARCGRAVE, G. Historia rervm natvralium Brasiliae libri octo ... In: Historia Naturalis Brasiliae. Lvgdv[nvm] Batavorvm \& Amstelodami: Fransiscum Hackium \& Lud[ovicum] Elizevirium, 1648, p. 1-283; PISO, G. De Indiae Utriusque re naturali et medica Libri quatuordecim, Quorum contenta pagina sequens exhibet. Amstelaedami: Ludovicum et Danielem Elzevirios, 1658.

34 Vide H. Niesters. In: BLÜCHEL, K. G. (Org.). Die Jagd. Köln: Könemann Verlagsgesellschaft, 1999; CHARBONNEAU-LASSAY, L. El bestiario de Cristo: el simbolismo animal en la Antigüedad y la Edad Media. Palma de Mallorca: Sophia Perennis, 1997; CHAMERLAT, C. A. de. Falconry and art. London: Sotheby's Publications, 1987; COOPER, J. C. Symbolic \& mythological animals. London: Aquarian Press, 1992; VRIES, A. de. Dictionary of symbols and imagery. Amsterdam: North-Holland Publishing, 1984. Vide BOEHRER, B. T. Parrot culture: our 2,500-year-long fascination with the world's most talkative bird. Piladelphia: University of Pennsylvania Press, 2004; PIEPER, R. Papagayos americanos, mediadores culturales entre dos mundos. In: STOLS, E.; THOMAS, W.; VERBERCKMOES, J. (Ed.). Naturalia, Mirabilia \& Monstrosa en los Imperios Ibéricos. Louvain: Presses Universitaires de Louvain, 2oo6; TEIXEIRA, D. M. (Org.). Brasil Holandês: a Coleção Niedenthal, o Animaux et oiseaux e o Nauralien-Buch de Jacob Wilhelm Griebe. Rio de Janeiro: Editora Index, 1998. 
explicar a escolha de seriemas, anhumas, surucuás, tucanos, juruvas, pica-paus, certas pombas e vários pássaros, mas não justifica a presença, por exemplo, de bacuraus e corujas de plumagem discreta e aparência muito similar a de seus congêneres do Velho Mundo.

Sugerida pelos numerosos vocábulos tupis e pela grande diversidade de motivos, a possível existência de um copioso material de apoio não impediria que dez aves fossem incluídas em mais de uma tela de Hoflössnitz, havendo mesmo o exemplo de um único pássaro retratado em três obras independentes (tab. 2). Esse aparente paradoxo, contudo, talvez reflita apenas a dificuldade encontrada pelos artistas do século XVII em ordenar um conjunto de animais desconhecidos, pois alguns desses quadros mostram exemplares da mesma espécie com nítidas diferenças na plumagem ${ }^{36}$ ou com nomes diversos e algumas variações de colorido ${ }^{37}$, enquanto outras pinturas reproduzem ilustrações muito distintas de uma mesma ave ${ }^{38}$. Por faltarem referências sobre um dos modelos utilizados, torna-se difícil especular se as duas pinturas de juruvas (Momotus momota; pinturas 58 e 70) ajustam-se a qualquer um desses casos (vide tab. 2).

\section{Novidades do além-mar}

Desde o século XV, humanistas alemães como Conrad Celtis (14591508) e Jacob Wimpheling (1450-1528) utilizariam a clássica Germania de Tácito para lançar ataques cada vez mais ferozes à Igreja de Roma, vista como corrupta e decadente. Pano de fundo da disputa travada entre o papa e o imperador do Sacro Império Romano Germânico pelo comando da cristandade, os textos de Celtis e Wimpheling buscavam a ideia de um pujante mundo silvestre que, desde a Antiguidade, mostrar-se-ia avesso aos males e vícios da civilização latina. Com o advento da Reforma, esse mito levaria a um renascimento da história e geografia teutônicas, conquistando espaço nas cortes de Frederick III, “o Pio”, eleitor palatino (1515-1576) e Rudolf II de Habsburgo (1552-1612). Em meados do século XVII, porém, o apelo nativista enfrentaria a indiferença de uma nobreza seduzida pelos refinamentos de um racionalismo precursor do futuro Século das Luzes e as misérias de um território destroçado pela Guerra

36 Caso do pato-do-mato (Cairina moschata) das pinturas 7 e 17, do pato-de-crista (Sarkidiornis melanotos) das pinturas 10 e 13 e do guará (Eudocimus ruber) das pinturas 42 e 49 .

37 Caso da anhuma (Anhima cornuta) das pinturas 39 e 56 , do xexéu (Cacicus cela) das pinturas $41 \mathrm{l}$ e 79 e do corrupião (Icterus icterus) das pinturas 4, 5o e 68.

38 Caso do maguari (Ardea cocoi) das pinturas 35 e 78 , da seriema (Cariama cristata) das pinturas 37 e 43 e do jacurutu (Bubo virginianus) das pinturas 36 e 69 . 
dos Trinta Anos (1618-1648). Entre outras consequências devastadoras, essa luta fratricida terminaria por aniquilar as matas locais, destruição concluída pela Grande Guerra do Norte (1700-1721) e pela cobiça de príncipes interessados no ganho fácil obtido com a venda da madeira de lei remanescente para os estaleiros da Inglaterra, França e Holanda ${ }^{39}$.

Conquanto marcasse profundamente o processo de formação da identidade nacional alemã, a mística em torno das florestas e da pretensa grandeza rústica e viril de seus primeiros habitantes parece ter exercido um papel secundário na corte da Saxônia seiscentista, então considerada uma das mais perdulárias da Europa. Sob o crescente efeito de um absolutismo barroco destinado a suplantar os ideais renascentistas, a caça conservaria pouco de seu caráter aventureiro e bucólico, convertendo-se em uma diversão aristocrática capaz de chegar a extremos inconcebíveis em termos de luxo. Por toda parte multiplicavam-se os "castelos de caça" e outras construções suntuosas dignas do poderio e ambições de seus proprietários, enquanto as atividades cinegéticas eram transformadas em verdadeiras cerimônias de ostentação e intrincados joguetes palacianos. Em 1662, por exemplo, Johann Georg II, príncipe eleitor da Saxônia, tomaria o disfarce de Diana para comandar uma grande caçada onde todos os convidados deviam comparecer fantasiados. Além de dois gaiteiros e de uma multidão de serviçais, os participantes eram seguidos por incontáveis matilhas de cães e podiam apreciar o espetáculo de ursos, lontras e outros animais selvagens enjaulados. Conforme era comum na época, as comemorações culminavam em um refinado festim capaz de durar dias ou mesmo semanas ${ }^{40}$.

Não raro, os "castelos de caça” da Alemanha eram levantados entre terras agrícolas situadas nos arredores das cidades, artifício muitas vezes empregado para lhes conferir um pretenso "caráter produtivo" capaz de se contrapor aos luxos excessivos e abrandar os murmúrios dos insatisfeitos burgueses citadinos. Como as muralhas haviam caído em desuso, esses prédios cada vez mais assumiam o aspecto de vilas suburbanas parcialmente inspiradas nos modelos adotados pela elite de Veneza $^{41}$. A princípio, semelhante descrição parece ajustar-se ao Castelo de Hoflössnitz - um modesto pavilhão se comparado a outros edifícios análogos existentes na Saxônia. Também localizado nos arredores de

39 Vide SCHAMA, S. Landscape and memory. New York: Vintage Books, 1995.

40 Vide BESCHORNER, H. Die Hoflössnitz bei Dresden. Geschichtliche Wanderfahrten, v. 10, p. 1-40, 1931; WEIDNER-WEIDEN, H. In: BLÜCHEL, K. G. (Org.). Die Jagd. Köln: Könemann Verlagsgesellschaft, 1999; WATANABE-O'KELLY, H. Court culture in Dresden: from Renaissance to Baroque. Houndmills: Palgrave, 2002.

41 Vide WEIDNER-WEIDEN, H. In: BLÜCHEL, K. G. (Org.). Die Jagd. Köln: Könemann Verlagsgesellschaft, 1999 . 
Dresden, o famoso "castelo de caça” de Moritzburg constitui um exemplo cabal nesse sentido, embora só tenha alcançado toda sua pompa com as reformas introduzidas no projeto quinhentista original por Johann Georg II e Friedrich Augustus I, “o Forte” (1694-1733).

Com a acelerada expansão do comércio europeu e a autêntica revolução científica observada no século XVII ${ }^{42}$, o interesse por artigos raros ou exóticos ganharia novos adeptos entre os membros de uma aristocracia profundamente envolvida na ostentação cortesã e preocupada em reafirmar seu papel de protetora das artes e das ciências ${ }^{43}$. Nesse universo em rápida transformação, a nobreza da Saxônia logo desenvolveria uma especial predileção por itens extraordinários dignos das Kunstkammern e dos "gabinetes de curiosidades", acervos que atingiriam seu ápice com a Grüne Gewölbe, a inigualável coleção de arte e itens diversos reunida pelos príncipes eleitores, notadamente Friedrich Augustus I ${ }^{44}$. Cada vez mais seduzidos pelas novidades trazidas do outro lado do oceano, os governantes locais usariam motivos do Oriente como ornamentação do seu magnífico palácio de verão em Pillnitz e escolheriam imagens de diferentes povos do mundo - inclusive indígenas peruanos - na decoração do Residenzschloss de Dresden, enquanto o Castelo de Pretzch - situado às margens do Elba - chegaria a abrigar dez composições alegóricas retratando nativos da Ásia, África e América em trajes típicos cercados por frutos e animais exóticos ${ }^{45}$.

Dentro de certos limites, essa mesma tendência logo se faria presente nos "castelos de caça”, pois os colecionadores de troféus passariam a cobiçar não apenas os tradicionais despojos de animais dignos de nota por seu tamanho, ferocidade ou robustez, mas também as "monstruosidades" fornecidas por exemplares anômalos ou portadores de deformações patológicas, os quais eram amiúde registrados em pinturas ${ }^{46}$. Por conseguinte, a existência de quadros de aves brasileiras no Castelo de Hoflössnitz não deve ser motivo de grande surpresa, tanto mais que os habitantes de Dresden se mostrariam muito sensíveis ao fascínio desper-

42 Sensu SHAPIN, S. The scientific revolution. Chicago: University of Chicago Press, 1996.

43 Vide RADL, E. M. Historia de las teorías biológicas. Madrid: Alianza Editorial, 1988.

44. Vide SYNDRAM, D. Die Schatzkammer Augustus des Starken. Leipzig: Seemann, 1999.

45 Vide JOPPIEN, R. The Dutch vision of Brazil: Johan Mauritis and his artists. In: BOOGAART, E.; HOETINK, H. R.; WHITEHEAD, P. J. P. (Ed.). Johan Mauritis van Nassau-Siegen I604-I679: a humanist prince in Europe and Brazil. The Hague: Johan Maurits van Nassau Stichting, 1979, p. 297-376; THOMSEN, T. Albert Eckhout ein Niederländischer Maler und sein Gönner Moritz der Brasilianer ein Kulturbild aus dem I7. Jahrhundert. Kopenhagen: Ejnar Munksgaard, 1938; WHITEHEAD, P. J. P.; BOESEMAN, M. A portrait of Dutch I7th century Brazil: animals, plants and people by the artists of Johan Maurits of Nassau. Amsterdam: North-Holland Publishing, 1989.

46 Vide WEIDNER-WEIDEN, H. In: BLÜCHEL, K. G. (Org.). Die Jagd. Köln: Könemann Verlagsgesellschaft, 1999 . 

pelo Thier Buch de Zacharias Wagener (1614-1668) ${ }^{47}$ e o Naturalien-Buch de Jacob Wilhelm Griebe (1639-1713) ${ }^{48}$. Entre os vários exemplos dispo-

47 Nascido em 9 de maio de $\mathbf{1 6 1 4}$ no seio da modesta família de um pequeno clérigo, Zacharias Wagener afastou-se de Dresden com apenas vinte anos de idade para tentar a sorte em terras distantes, engajando-se - em 1634- como um dos mercenários enviados pela Companhia das Índias Ocidentais ao nordeste do Brasil, invadido quatro anos antes durante a expansão flamenga no Atlântico. Esse seria o começo de três décadas e meia de serviços prestados aos Países Baixos e o início de uma notável escalada dentro da hierarquia das companhias de comércio holandesas, trajetória que culminaria na obtenção do posto de vice-almirante e do cargo de governador da colônia do Cabo da Boa Esperança. Após sete anos de permanência no Novo Mundo (1634-1641) como comandado de Johan Maurits van Nassau-Siegen, Wagener retornaria à casa dos pais durante um breve período (12 de outubro de 1641 a 10 de fevereiro de 1642), viajando em seguida para o Oriente a soldo da Companhia das Índias Orientais (29 de setembro de 1642), não voltando jamais à sua cidade natal. Elaborado durante a estada no Brasil, o Thier Buch teria chegado a Dresden nessa oportunidade, percorrendo um tortuoso caminho até ser incorporado ao acervo do Kupferstich-Kabinett de Dresden. Ao todo, o volume em questão abriga 110 pranchas dedicadas aos animais, plantas e habitantes do Brasil, ilustrações que se encontram frequentemente acompanhadas de notas explicativas. Vide TEIXEIRA, D. M. (Org.). Brasil Holandês: documentos da biblioteca universitária de Leiden, o Thierbuch e a Autobiografia de Zacharias Wagener e os quadros do Weinbergschlösschen de Hoflössnitz. Rio de Janeiro: Editora Index, 1997.

48 Jacob Wilhelm Griebe teria nascido em Dresden no ano de 1639 como o segundo filho de Georg Gotthelf Griebe, quartel-mestre de guerra do príncipe eleitor da Saxônia e senhor dos morgados de Oberlangenau e Niederlangenau, ambos situados nas proximidades de Brand. Destinado à carreira diplomática, teve sua aristocrática formação complementada por um Kavaliertour típico das abastadas famílias da época, percorrendo a França, a Itália e a Suíça entre 29 de maio de 166ı e 8 de agosto de 1664. Aceito no serviço de Johann Georg II pouco tempo depois de retornar à sua cidade natal, o jovem Griebe participaria, na qualidade de secretário, da delegação enviada em 1665 à Dinamarca para obter a mão da princesa Anna Sophie para o futuro Johann Georg III. Ao suceder o pai como quartel-mestre e receber o título de conselheiro do príncipe eleitor, abandonaria em definitivo as relações exteriores, casando-se em seguida com Rahel Magdalena Hanitsch. Em 168o, com o fim prematuro de Johann Georg II, o casal se retiraria para as propriedades de Oberlangenau e Niederlangenau, onde viveriam por mais trinta anos até o falecimento de Rahel em 1712, evento logo secundado pela morte do próprio Griebe em 1713. Na qualidade de filho mais novo dessa união, o magistrado Gottfried Heinrich Griebe demonstraria um marcado interesse pela trajetória de sua família, apego que o levaria a enriquecer o diário do Kavaliertour de Jacob Wilhelm Griebe com retratos confeccionados para este fim e a colaborar intensamente na organização das ilustrações avulsas de animais e plantas reunidas por seu pai em uma suntuosa iconografia, tarefa concluída entre 1680 e 1708 . O volume resultante constituiria um notável tributo à conhecida paixão de Jacob Wilhelm Griebe pelos "gabinetes de curiosidades" e as ménageries. Depositado no Departamento de Manuscritos da Sächsische Landesbibliothek de Dresden, o Naturalien-Buch ou Liber Naturalium de Griebe consiste de um encorpado tomo contendo 612 ilustrações, das quais cinquenta guardam alguma relação com o material do Brasil Holandês e/ou retratam espécies pertencentes à fauna e flora sul-americana. Desse montante, 34 chamam a atenção por serem cópias pouco acuradas de aquarelas do Thierbuch de Zacharias Wagener, enquanto dez outras se destacam por figurarem exemplares trazidos do Novo Mundo, 
níveis, esse último volume informa que, no ano de 1688, o príncipe eleitor Johann Georg III (1680-1691) obteria na Holanda um sagui (Callithrix jacchus) e um guará (Eudocimus ruber) por preços elevadíssimos, pagando pelo primeiro oitenta táleres e pelo segundo o inacreditável montante de cem táleres, quantia mais ou menos equivalente aos proventos anuais de um artesão qualificado ${ }^{49}$.

Malgrado não estejam datados ou assinados, os óleos de aves exóticas que ornamentam o salão principal de Hoflössnitz têm sido frequentemente atribuídos a Albert Eckhout ${ }^{50}$. Entretanto, apesar de realmente emularem parte do material enviado por Nassau para o eleitor de Brandemburgo $^{51}$, a qualidade dessas pinturas parece desautorizar semelhante conjectura devido às patentes diferenças encontradas na forma, colorido e proporções dos exemplares figurados. Na verdade, os quadros em questão integram um conjunto singular, conferindo a nítida impressão de obras elaboradas por um artista capaz de produzir apenas cópias bastante inferiores aos modelos originais ${ }^{52}$. Não obstante, os nomes empregados e certos detalhes presentes em várias telas parecem ser indicativos da influência de algum personagem familiarizado com a fauna sul-americana,

testemunho eloquente do intenso tráfico de animais e plantas observado entre a Europa e os territórios ultramarinos durante o século XVII. Vide TEIXEIRA, D. M. (Org.). Brasil Holandês: a Coleção Niedenthal, o Animaux et oiseaux e o Nauralien-Buch de Jacob Wilhelm Griebe. Rio de Janeiro: Editora Index, 1998.

49 Entre 1690 e 1750, um táler era suficiente para comprar de 45 a 60 litros de centeio, 40 a 60 litros de trigo ou 6 quilos de carne de porco, cordeiro ou gado em boa parte da Alemanha. Na segunda metade do século XVIII, um artesão de Göttingen recebia 1/3 de táler por dia, enquanto a jornada de um operário da construção valia ı/6 de táler e aquela de um trabalhador não qualificado apenas $1 / 7$ de táler (Renate Pieper, in lit.). Vide TEIXEIRA, D. M. O mito da natureza intocada: as aves do Brasil Holandês (16241654) como exemplo para a história recente da fauna do Novo Mundo. Tese (Doutorado em Zoologia) - Programa de Pós-Graduação em Zoologia, Museu Nacional, Universidade Federal do Rio de Janeiro, Rio de Janeiro, 1999.

50 Vide BESCHORNER, H. Die Hoflössnitz bei Dresden. Dresdner Geschichtsbläter, v. 13, n. 1, p. 209-226, 1904; BESCHOR NER, H. Die Hoflössnitz bei Dresden. Dresdner Geschichtsbläter, v. 13, n. 2, p. 239-247, 1904; SCHAEFFER, E. Bilder brasilianischer Vögel in einem deutschen Jagdschlößchen. Staden Jahrbuch, v. 14, p. 175-183, 1966; SCHAEFFER, E. Pássaros do Brasil: Albert Eckhout. Rio de Janeiro: Agir, 1970.

$51 \quad$ No caso, as já mencionadas Icones Volatilium e os Libri Principis, que chegaram às mãos do príncipe eleitor de Brandemburgo em 1652. Vide nota 12.

52 Além de soberbos originais atribuídos a Eckhout, as Icones Volatilium incluem algumas ilustrações de qualidade inferior pertencentes a um artista desconhecido e bem menos habilidoso. Tal diferença torna-se muito patente quando ambos retratam a mesma ave, pois as figuras da seriema (Cariama cristata) e do maguari (Ardea co$c o i$ ) observadas nas folhas 35 e 65 dessa coletânea não passam de esboços grosseiros quando comparadas às excelentes pinturas das folhas $37 \mathrm{e} 69$. No entanto, todas essas quatro imagens seriam reproduzidas nos quadros de Hoflössnitz (vide pinturas 35 versus 78, 37 versus 43), detalhe que parece reforçar a hipótese de Eckhout não ser o autor do trabalho realizado. 
o que torna razoável a hipótese recorrente de Eckhout ter atuado apenas como supervisor dos trabalhos realizados. A julgar pelas informações disponíveis, Christian Schiebling (1603-1663) seria o autor tanto das pinturas de animais encomendadas para os palácios de Pillnitz e Moritzburg quanto dos interessantes retratos de linces, javalis, cervos, lobos, percas, focas etc. observados no teto dos aposentos destinados ao príncipe eleitor. Não obstante, suas composições guardam pouca semelhança com os quadros de aves encontrados no salão principal de Hoflössnitz, abrindo espaço para especulações em torno dos nomes de Centurio Wiebel, Augustus Schumann, Johann Fincke, Bartholomeu Stronbel, Georg Dürr, Andreas Vogel e outros artistas subvencionados pela corte da Saxônia ${ }^{53}$.

Além de coerente com os fatos conhecidos, a suposição de Albert Eckhout não ser o autor dos quadros de Hoflössnitz também poderia explicar certas incongruências observadas nas dez obras do Castelo de Pretzch que lhes eram atribuídas. Transferidas posteriormente para o Castelo de Schwedtam der Oder, essas composições terminariam sendo destruídas durante a Segunda Grande Guerra, delas só restando fotografias em preto e branco ${ }^{54}$. Apesar de precárias, as reproduções disponíveis chamam a atenção pelo aspecto um tanto grosseiro das telas originais, característica bastante evidente quando se compara a cena dedicada aos índios brasileiros com o "Homem Tapuia" e a "Mulher Tupi" pertencentes ao Nationalmuseet de Copenhague (fig. 30). Outrossim, salta aos olhos que quatro dessas pinturas incluam pelo menos seis imagens de aves muito semelhantes às encontradas nos quadros de Hoflössnitz (fig. 31 a 34), elenco composto por um pelicano (Pelecanus rufescens), um guará (Eudocimus ruber), uma ararajuba (Aratinga guarouba), um flamingo (Phoenicopterus ruber roseus), um corrupião (Icterus icterus)

53 Vide BESCHORNER, H. Die Hoflössnitz bei Dresden. Geschichtliche Wanderfahrten, v. 10, p. 1-40, 1931; HÜBNER, J. Kleine Beiträge zur Specialgeschichte der an dem Churfürstlich Sächsischen Hofe angestellten oder beschaftigten Künstler (vom 15 bis 18 Jahrhundert reichend). Archiv für Sächsische Geschichte, v. 2, p. 180-192, 1864; JOPPIEN, R. The Dutch vision of Brazil: Johan Mauritis and his artists. In: BOOGAART, E.; HOETINK, H. R.; WHITEHEAD, P. J. P. (Ed.). Johan Mauritis van Nassau-Siegen I604-I679: a humanist prince in Europe and Brazil. The Hague: Johan Maurits van Nassau Stichting. p. 297-376, 1979; LÖFFLER, F. Die Monumentalmalerei des Barock in Dresden. In: KREY, H. (Ed.). Jahrbuch zur Pflege der Künste. Dresden: Wolfgang Jess Verlag, 1956, p. 5-23; THOMSEN, T. Albert Eckhout ein Niederländischer Maler und sein Gönner Moritz der Brasilianer ein Kulturbild aus dem 17. Jahrhundert. Kopenhagen: Ejnar Munksgaard, 1938; WHITEHEAD, P. J. P.; BOESEMAN, M. A portrait of Dutch I7th century Brazil: animals, plants and people by the artists of Johan Maurits of Nassau. Amsterdam: North-Holland Publishing, 1989.

54. In THOMSEN, T. Albert Eckhout ein Niederländischer Maler und sein Gönner Moritz der Brasilianer ein Kulturbild aus dem I7. Jahrhundert. Kopenhagen: Ejnar Munksgaard, 1938. 
e uma espécie paludícola não identificada (pinturas 9, 38, 49, 58, 62 e 68). Alguns desses motivos parecem ser recorrentes nos trabalhos associados a Eckhout, pois o mesmo guará com a plumagem escarlate e asas abertas também aparece no teto da Oranjezaal em Huis ten Bosch, Haia $^{55}$, e no Élephant, uma das tapeçarias pertencentes à famosa série das Vieilles Indes dos Gobelins (fig. 35) ${ }^{56}$.

55 Construída entre 1645 e 1647 pelo Stadholder Frederik Hendrik, a Huis ten Bosch teve como responsável por sua decoração o arquiteto Jacob van Campen. Como Eckhout também teria vivido em Amersfoort entre o seu retorno do Brasil e a partida para Dresden (1644-1653), acredita-se que algum tipo de parceria possa ter sido estabelecida com van Campen. Existe uma grande discussão, entretanto, se a imagem do guará encontrada no teto da Oranjezaal seria da autoria do próprio Eckhout ou apenas estaria baseada em um dos seus estudos. Vide BUVELOT, Q. Jacob van Campen als schilder em tekenaar. In: HUISKEN, J.; OTTENHEYM, K.; SCHWARTZ, G. (Org.) Jacob van Campen: het klassieke ideaal in de Gouden Eeuw. Amsterdam: Architetura \& Natura Pers, 1995. p. 53-119; BUVELOT, Q. (Ed.). Albert Eckhout: a Dutch artist in Brazil. The Hague: Royal Cabinet of Paintings Mauritshuis, 2004; GELDER, H. E. van. Twee Braziliaanse schildpadden door Albert Eckhout. Oud Holland, v. 75, p. 5-30, 196o; JOPPIEN, R. The Dutch vision of Brazil: Johan Mauritis and his artists. In: BOOGAART, E.; HOETINK, H. R.; WHITEHEAD, P. J. P. (Ed.). Johan Mauritis van Nassau-Siegen I604-I679: a humanist prince in Europe and Brazil. The Hague: Johan Maurits van Nassau Stichting. p. 297-376, 1979; THOMSEN, T. Albert Eckhout ein Niederländischer Maler und sein Gönner Moritz der Brasilianer ein Kulturbild aus dem I7. Jahrhundert. Kopenhagen: Ejnar Munksgaard, 1938; WHITEHEAD, P. J. P.; BOESEMAN, M. A portrait of Dutch I7th century Brazil: animals, plants and people by the artists of Johan Maurits of Nassau. Amsterdam: North-Holland Publishing, 1989.

56 Efetuada em 1679 com Luís XIV de França, a última das grandes permutas realizadas por Nassau incluía 42 tableaux grandes e pequenos onde estavam retratados os mais diversos aspectos das terras e gentes do Brasil. De todas as "doações" efetuadas, nenhuma apresentaria efeitos mais extensos e duradouros, pois esse material teria servido de base para a elaboração de um conjunto de tapeçarias da famosa manufatura Gobelin, peças de ampla penetração por constituírem artigos de exibição por excelência fabricados em série. Formando as chamadas Anciennes indes, essas tapeçarias estavam destinadas a surgir apenas em 1687 , anos depois da morte da maioria dos envolvidos e quase uma década após a chegada dos originais de Nassau a Paris. Ao todo, seriam elaboradas oito composições distintas em dois formatos básicos (Grandes indes e Petites indes), as quais passariam a ser conhecidas pelos nomes de Le cheval rayé, Les deux taureaux, L'eléphant, Le chasseur indien, Le combat des animaux, Le roi porté, L'indien à cheval e Les pêcheurs. Maiores detalhes podem ser obtidos em BESINOVICH, M. Frans Post e Albert Eckhout, pintores holandeses do Brasil e as Tapeçarias das Índias dos Gobelins. Revista do Serviço do Patrimônio Histórico e Artístico Nacional, v. 7, p. 35-56, 1943; ENGERAND, F. Inventaire des tableaux du Roy redigé en I709 et I7Io par Nicholas Bailly, publié pour la première fois avec des additions et des notes. Paris: Ernest Leroux, 1889; ENGERAND, F. Inventaire des tableaux commandés et achetés par la Direction des Batiments du Roi (I709-I792). Paris: Ministère de Instruction Publique, 1901; FENAILLE, M. État général des tapisseries de la manufacture des Gobelins, depuis son origine jusqu'a nos jours, I6oo-I9oo. Paris: Imprimerie Nationale et Libraire Hachette, 1903-1907; GUIFFREY, J. J. Inventaire général du mobilier de la couronne sous Louis XIV (I663-I7I5). Paris: Imprimerie E. Ménard \& J. Augry, 1886; JARRY, M. L'exotisme dans l'art décoratif français au temp de Louis XIV. Bulletin de la Société 
Segundo os termos estabelecidos entre Albert Eckhout e os príncipes eleitores, o artista holandês deveria pintar retratos, paisagens, caçadas, cenas históricas e qualquer outro motivo escolhido pelo suserano, estando obrigado a trazer para a corte da Saxônia todo o material relativo "às Índias" (i. e. o Brasil) ainda em seu poder ${ }^{57}$. Essa última exigência parece ter sido atendida, pois o Naturalien-Buch de Jacob Wilhelm Griebe inclui meia dúzia de ilustrações de animais aquáticos do Novo Mundo muito semelhantes a originais pertencentes ao Theatrum rerum naturalium Brasiliae $^{58}$. Além da óbvia identidade observada em termos de estilo e do material empregado, essas seis pinturas conservam o nome tupi de cada espécie e se encontram acompanhadas de dois sugestivos comentários manuscritos aptos a reforçar consideravelmente a possível autoria de Albert Eckhout ${ }^{59}$. Traçadas pelo punho do próprio Griebe, a primeira

d'Études du XVIIe Siècle 36/37: 300-328, 1957; JARRY, M. Dessins et études provenant de l'atelier de Desportes concernant la Tenture des Indes, conservés à la bibliothèque de la Manufacture de Sèvres. Bulletin de la Société de l'Histoire de l'Art. Français 1957, p. 39-45, 1958; JARRY, M. Les Indes. Série triomphale de l'exotisme. Connaissance des Arts, p. 62-69, mai. 1959; JARRY, M. L'exotisme au temps de Louis XIV: Tapisseries des Gobelins et de Beauvais. Medizinhistorisches Journal, v. 11, p. 52-71, 1976; KROTOFF, M. H. (Org.). La tenture des anciennes et nouvelles Indes. Aix-en-Provence: Musée des Tapisseries, 1984; LARSEN, E. Frans Post: interprète du Brésil. Amsterdam: Colibris, 1962; SOUSA-LEÃO, J. de. Frans Post I6ı-I680. Rio de Janeiro: Livraria Kosmos Editora, 1973; THOMSEN, T. Albert Eckhout ein Niederländischer Maler und sein Gönner Moritz der Brasilianer ein Kulturbild aus dem I7. Jahrhundert. Kopenhagen: Ejnar Munksgaard, 1938; WHITEHEAD, P. J. P.; BOESEMAN, M. A portrait of Dutch 17 th century Brazil: animals, plants and people by the artists of Johan Maurits of Nassau. Amsterdam: North-Holland Publishing, 1989 .

Vide HÜBNER, J. Kleine Beiträge zur Specialgeschichte der an dem Churfürstlich Sächsischen Hofe angestellten oder beschaftigten Künstler (vom 15 bis 18 Jahrhundert reichend). Archiv für Sächsische Geschichte 2: 180-192, 1864; THOMSEN, T. Albert Eckhout ein Niederländischer Maler und sein Gönner Moritz der Brasilianer ein Kulturbild aus dem I7. Jahrhundert. Kopenhagen: Ejnar Munksgaard, 1938.

$5^{8}$ Vide TEIXEIRA, D. M. (Org.). Brasil Holandês: Miscellanea Cleyeri, Libri Principis \& Theatrum rerum naturalium Brasiliae. Rio de Janeiro: Editora Index, 1995; TEIXEIRA, D. M. (Org.). Brasil Holandês: a Coleção Niedenthal, o Animaux et oiseaux e o Nauralien-Buch de Jacob Wilhelm Griebe. Rio de Janeiro: Editora Index, 1998.

59 Localizadas entre as folhas 203 e 208 , essas seis pinturas retratam uma lagosta ( $\mathrm{Pa}$ linurus echinatus) e cinco espécies distintas de peixes do Novo Mundo (Sphyraena barracuda, Elops saurus, Tarpon atlanticus, Euthynnus alleteratus e Ogcocephalus vespertilio), tendo sido executadas a óleo sobre o mesmo papel branco bastante delgado empregado em numerosas imagens do Theatrum rerum naturalium Brasiliae. No Naturalien-Buch, porém, as figuras terminariam sendo recortadas e coladas em quadriláteros de um segundo papel branco mais espesso. Tal manejo eliminou todas as anotações originais porventura existentes, embora os nomes tupis das diferentes espécies ("potiatinga”, "guebi”, “uubaranáçaguaçu”, "camarupi”, "curuata pinima” e "guacucua") tenham sido transcritos graças à providencial intervenção de um copista desconhecido. Vide TEIXEIRA, D. M. (Org.). Brasil Holandês: Miscellanea Cleyeri, Libri Principis \& Theatrum rerum naturalium Brasiliae. Rio de Janeiro: Edi- 
dessas anotações (fls. 203) caracteriza tais figuras como "trazidas das Índias Orientais por um pintor que as elaborou de acordo com exemplares vivos"60, enquanto a segunda (fls. 510) acrescenta que todas lhe teriam sido “ofertadas pelo pintor que as desenhou e trouxe das Índias Orientais"61.

$\mathrm{O}$ fato de os quadros de Hoflössnitz estarem claramente baseados nos originais cedidos ao eleitor de Brandemburgo em $1652^{62}$ acentua as numerosas dúvidas relativas ao acervo iconográfico levado para Dresden por Albert Eckhout. Cabe especular, por exemplo, se o artista holandês dispunha de cópias daquelas primeiras ilustrações ou teria sido forçado a providenciá-las - em data ignorada - a partir dos Libri Principis e sobretudo das Icones Volatilium, cuja organização seria concluída por Christian Mentzel, médico particular de Friderich Wilhelm, apenas em $1660^{63}$. Certas fontes identificam essas supostas reproduções com os chamados Cadernos de Leningrado, alternativa improvável face à qualidade das imagens e às próprias espécies retratadas, pois faltam várias aves presentes nos quadros de Hoflössnitz ${ }^{64}$. Apesar de nenhuma coletânea capaz de assumir esse papel ter sido descoberta até o momento, vale lem-

tora Index, 1995; TEIXEIRA, D. M. (Org.). Brasil Holandês: a Coleção Niedenthal, o Animaux et oiseaux e o Nauralien-Buch de Jacob Wilhelm Griebe. Rio de Janeiro: Editora Index, 1998.

6o "Dieser und folgende fünf Blätter, sind von einem Mahler in Ost India nach den leben gezeichnet und mit heraus gebracht worden" no original. Nesse caso, a confusão entre as Índias Ocidentais e Orientais não chega a ser surpreendente. Vide TEIXEIRA, D. M. (Org.). Brasil Holandês: a Coleção Niedenthal, o Animaux et oiseaux e o NauralienBuch de Jacob Wilhelm Griebe. Rio de Janeiro: Editora Index, 1998.

61 "Sind von einem Mahler, welcher sie in Ost India gezeichnet, mit heraus gebracht und mir verehret worden" no original. Vide TEIXEIRA, D. M. (Org.). Brasil Holandês: a Coleção Niedenthal, o Animaux et oiseaux e o Nauralien-Buch de Jacob Wilhelm Griebe. Rio de Janeiro: Editora Index, 1998.

62 Essa relação seria marcada a ponto de reproduzir originais inacabados e obras não pertencentes a Eckhout, caso da figura de um martim-pescador (Chloroceryle amazona) pertencente às Icones Volatilium (pintura 51) e da imagem em preto branco de uma curicaca (Theristicus caudatus) existente no primeiro volume dos Libri Principis (pintura 65). De certa forma, torna-se difícil entender como ambas as situações foram mantidas sob a eventual supervisão do artista holandês.

63 Vide TEIXEIRA, D. M. O mito da natureza intocada: as aves do Brasil Holandês (1624-1654) como exemplo para a história recente da fauna do Novo Mundo. Tese (Doutorado em Zoologia) - Programa de Pós-Graduação em Zoologia, Museu Nacional, Universidade Federal do Rio de Janeiro, Rio de Janeiro, 1999.

64. Depositado nos arquivos da Academia de Ciências de São Petersburgo, os chamados Cadernos de Leningrado abrigam 283 cópias de originais do Theatrum rerum naturalium Brasiliae e do Libri Principis cuja autoria não pode ser estabelecida até o momento. Vide BOESEMAN, M.; HOLTHUIS, L. B.; HOOGMOED, M. S.; SMEENK, C. Seventeenth century drawings of Brazilian animals in Leningrad. Zoologische Verhandelingen, v. 267, p. 1-189, 1990; WHITEHEAD, P. J. P.; BOESEMAN, M. A portrait of Dutch I7th century Brazil: animals, plants and people by the artists of Johan Maurits of Nassau. Amsterdam: North-Holland Publishing, 1989. 
brar que o Kupferstich-Kabinett de Dresden abriga um enigmático volume ricamente encadernado com versões grosseiras de diversas pinturas dos Libri Principis, entre as quais 24 aves representadas em Hoflössnitz ${ }^{65}$. Conhecido como Animaux et oiseaux, esse trabalho de autoria ignorada parece remontar à segunda metade do século XVII, havendo vagos relatos de sua incorporação à centenária Kurfürstliche Kunstkammer dos príncipes eleitores da Saxônia após o término da Guerra dos Trinta Anos (1618-1648) ${ }^{66}$. Embora pouco contribua para dirimir as dúvidas existentes, essa última iconografia pelo menos indica que cópias do material depositado em Brandemburgo poderiam estar disponíveis em Dresden durante a estada de Eckhout ${ }^{67}$.

Para certos autores, a decoração do Castelo de Hoflössnitz obedeceria a um projeto assaz "coerente" e muito "adequado a um príncipe renascentista" ${ }^{68}$. Ainda de acordo com tais análises, os 16 painéis de animais marinhos (percas, focas etc.) e os 24 painéis de mamíferos (ursos, lobos, linces, cervos, lebres, javalis etc.) encontrados no teto dos aposentos destinados ao príncipe eleitor não só personificariam a força viril e as virtudes encontradas na caça, como ressaltariam o incontestável comando por ele exercido sobre a terra e as águas. Em contrapartida, os cômodos de sua consorte seriam ornamentados com dezesseis painéis retratando gênios carregando grande diversidade de flores, numerosos amores com motivos florais e alegorias relativas às artes e às ciências (Arithimetica, Pictura, Grammatica, Musica, Rhetorica, Astronomia, Geometria etc.). Nas paredes do salão principal, dezesseis figuras femininas personificando as virtudes (Benevolentia, Vigilantia, Fortitude etc.) e 43 pinturas emblemáticas com lemas morais ajudariam a comple-

65 Tratam-se das aves representadas nas pinturas 3, 4, 5, 8, 13, 15, 23, 26, 28, 30, 33, 40, 41, $47,5^{0}, 5^{2}, 53,5^{6}, 5^{8,63}, 69,74,7^{6}$ e 8 o.

66 Compare WHITEHEAD, P. J. P.; BOESEMAN, M. A portrait of Dutch I7th century Brazil: animals, plants and people by the artists of Johan Maurits of Nassau. Amsterdam: North-Holland Publishing, 1989 versus TEIXEIRA, D. M. (Org.). Brasil Holandês: a Coleção Niedenthal, o Animaux et oiseaux e o Nauralien-Buch de Jacob Wilhelm Griebe. Rio de Janeiro: Editora Index, 1998.

67 O embaixador Mário Calábria, responsável pela representação brasileira na antiga Berlim oriental (1978-1983), teve a oportunidade de adquirir seis cópias dos quadros de Hoflössnitz postas a venda por Peretz em outubro de 1978 , obras posteriormente cedidas à Fundação Oscar Americano, São Paulo. Um pouco menores que os modelos originais (90 x $72 \mathrm{~cm}$ ), essas telas não apresentam maior interesse, constituindo meras reproduções elaboradas, na melhor das hipóteses, durante o século XIX. Vide também WHITEHEAD, P. J. P.; BOESEMAN, M. A portrait of Dutch I7th century Brazil: animals, plants and people by the artists of Johan Maurits of Nassau. Amsterdam: North-Holland Publishing, 1989.

68 MASON, P. Eighty Brazilian birds for Johann Georg. Folk, Journal of the Danish Ethnographic Society, v. 43, p. 103-121, 2001. 
tar um laudatório perfil do poder reinante, enquanto os quadros das aves colocados no teto estenderiam seu domínio aos ares, portanto a todo o orbe. Ao combinar elementos da terra, água e ar com as virtudes masculinas e femininas esperadas de governantes ideais, o Castelo de Hoflössnitz tornar-se-ia simultaneamente uma Kunstkammer, um microcosmo e um espaço de afirmação dos méritos e da incontestável autoridade dos príncipes eleitores ${ }^{69}$.

Apesar de engenhosa e talvez verdadeira em alguns de seus contornos mais gerais, semelhante proposta destoa das pinturas de aves exóticas encontradas no salão principal, pois não faltariam espécies europeias aptas a cumprir a mesma função e tampouco artistas dispostos a retratá-las antes da chegada de Albert Eckhout a Dresden em 1653. A julgar pelas datas de alguns painéis dos aposentos do eleitor - o mais velho de 1625 e o mais recente de 1652 - a decoração de Hoflössnitz compreenderia trabalhos anteriores e posteriores à conclusão do edifício em 1650, detalhe indicativo de que o interior do palacete só assumiria seu aspecto definitivo através de diversas intervenções promovidas ao longo do tempo. Em verdade, vários dos quadros do teto do salão parecem ter sido adaptados aos seus nichos, sofrendo uma manipulação grosseira o suficiente para permitir que as molduras cobrissem parcialmente os nomes e até mesmo as espécies representadas, equívoco não observado nos demais painéis ${ }^{70}$. Apesar de existirem várias interrogações sobre os verdadeiros desígnios dos príncipes eleitores e a natureza dos trabalhos desenvolvidos por Eckhout na corte da Saxônia, essas pinturas parecem constituir uma inesperada adição ao projeto inicial de Hoflössnitz, devendo ser entendidas sobretudo como o resultado do fascínio da Europa seiscentista pelas surpreendentes novidades vindas do outro lado do oceano.

69 MASON, P. Eighty Brazilian birds for Johann Georg. Folk, Journal of the Danish Ethnographic Society, v. 43, p. 103-121, 2001.

70 Vide também WHITEHEAD, P. J. P.; BOESEMAN, M. A portrait of Dutch I7th century Brazil: animals, plants and people by the artists of Johan Maurits of Nassau. Amsterdam: North-Holland Publishing, 1989 . 


\section{Imagens do Artigo: Os quadros de aves tropicais do Castelo de Hoflössnitz na Saxônia e Albert Eckhout (ca. 1610-1666), artista do Brasil Holandês}

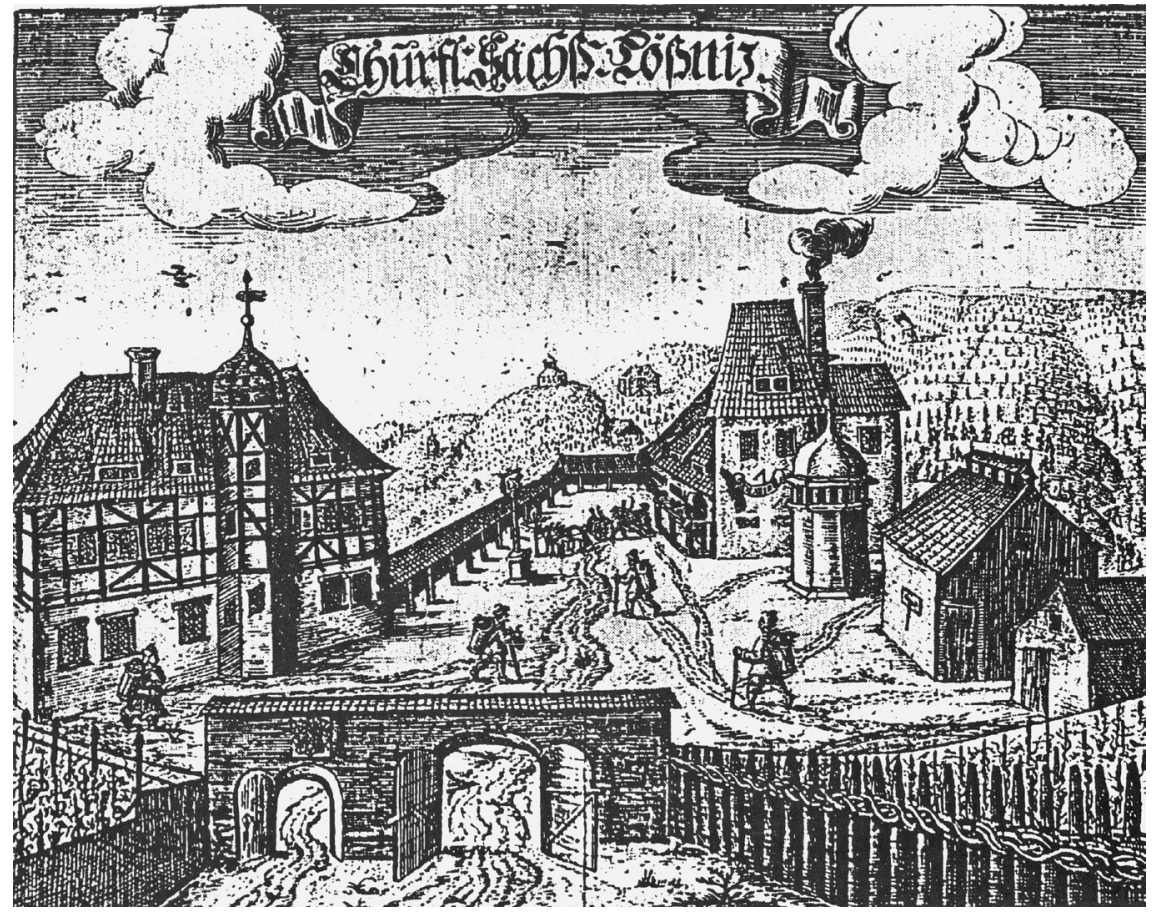

Figura 1. Aspecto do Castelo de Hoflössnitz segundo o Klein Vinicultur-Büchlein de Paul Knohll (1667). 


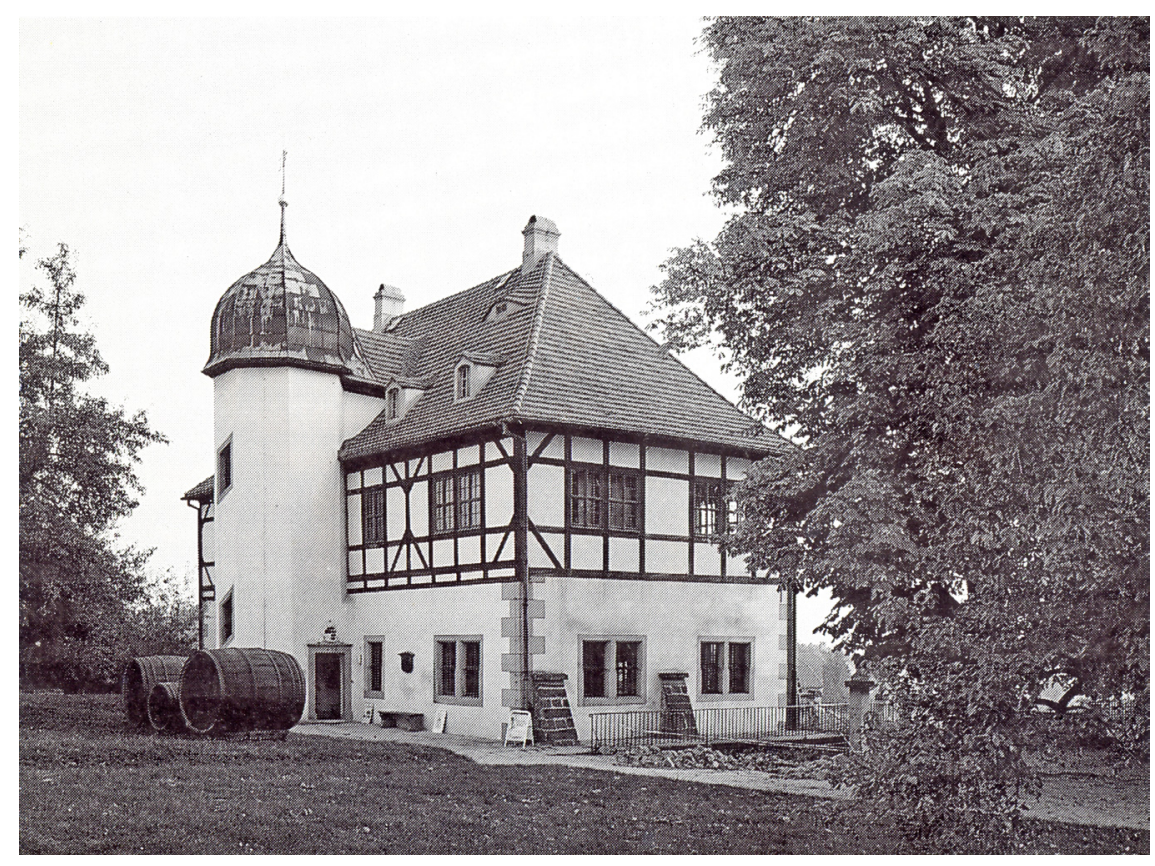

Figura 2. Aspecto do Castelo de Hoflössnitz (em 1996). 


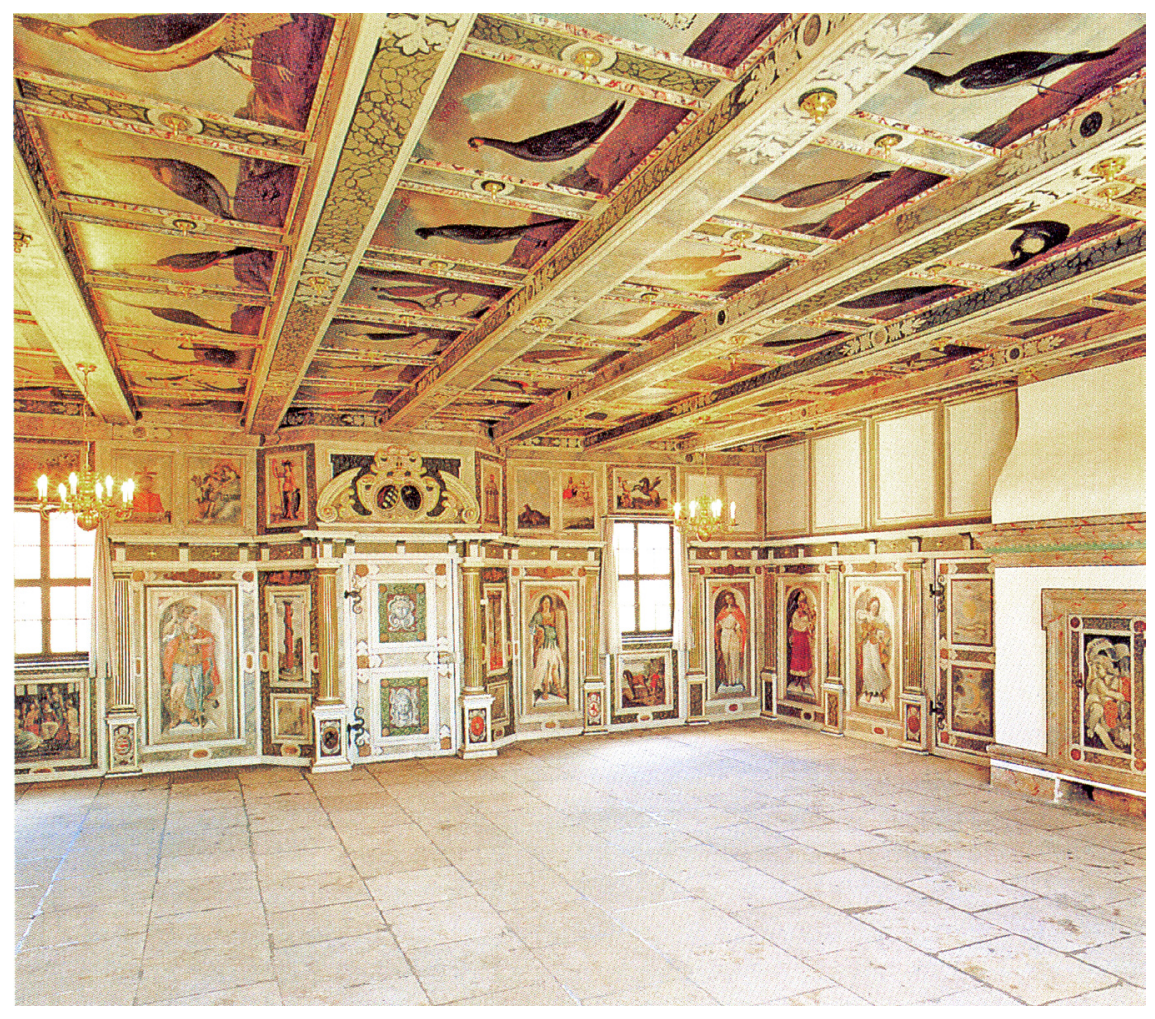

Figura 3. Aspecto do salão principal do Castelo de Hoflössnitz (em 1996). 


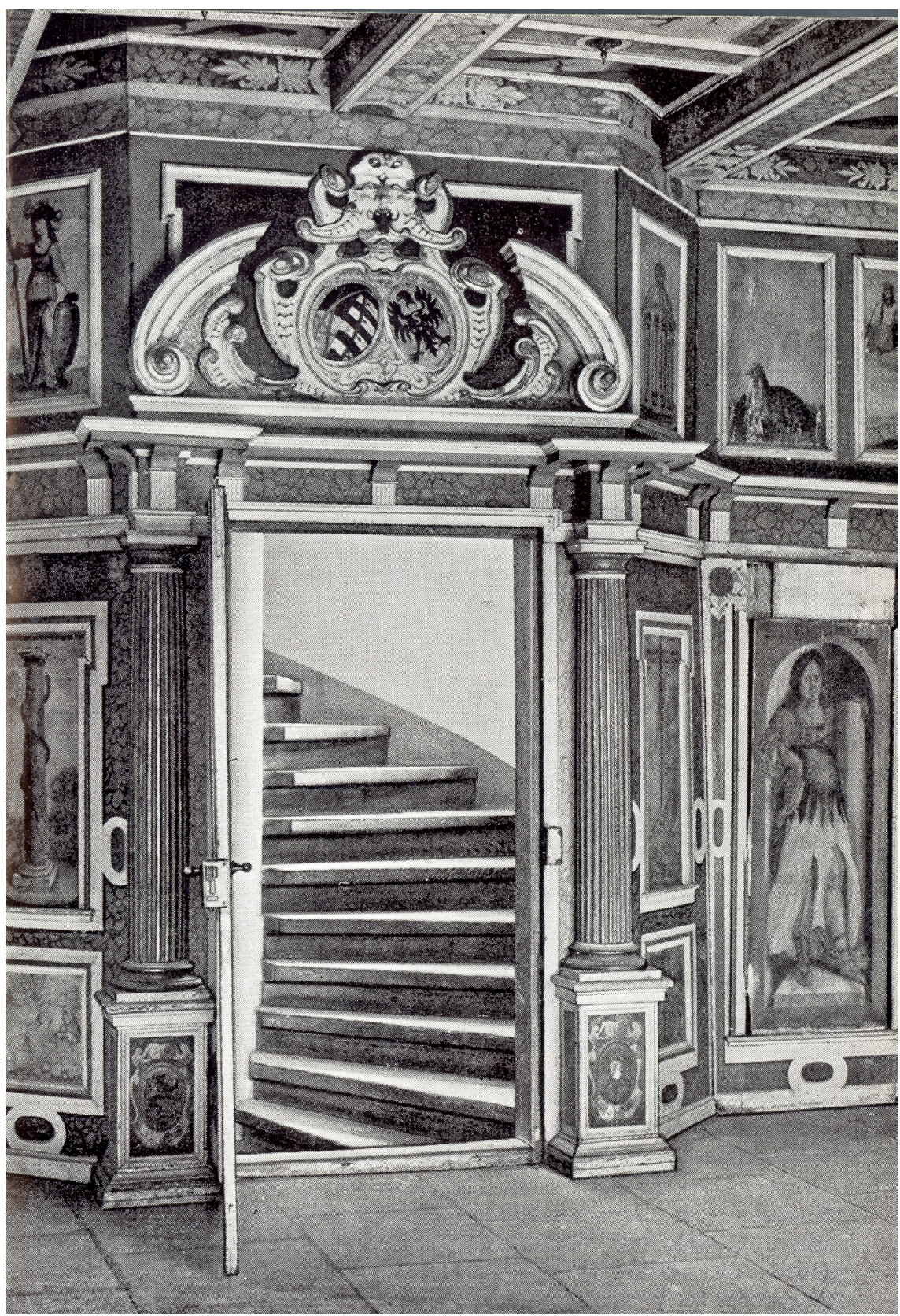

Figura 4. Aspecto do portal de entrada para o salão principal do Castelo de Hoflössnitz (em 1980). 


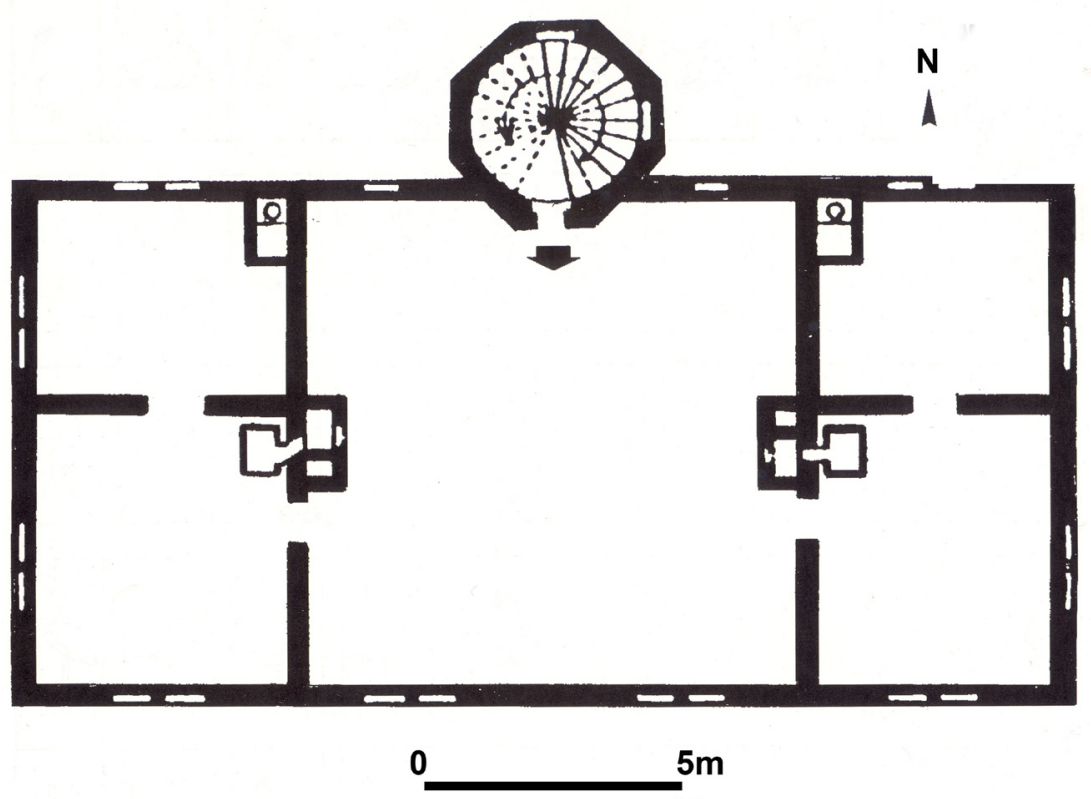

Figura 5. Planta do segundo pavimento do edifício (baseada em Die Hoflössnitz bei Dresden de Hans Beschorner, 1904). 


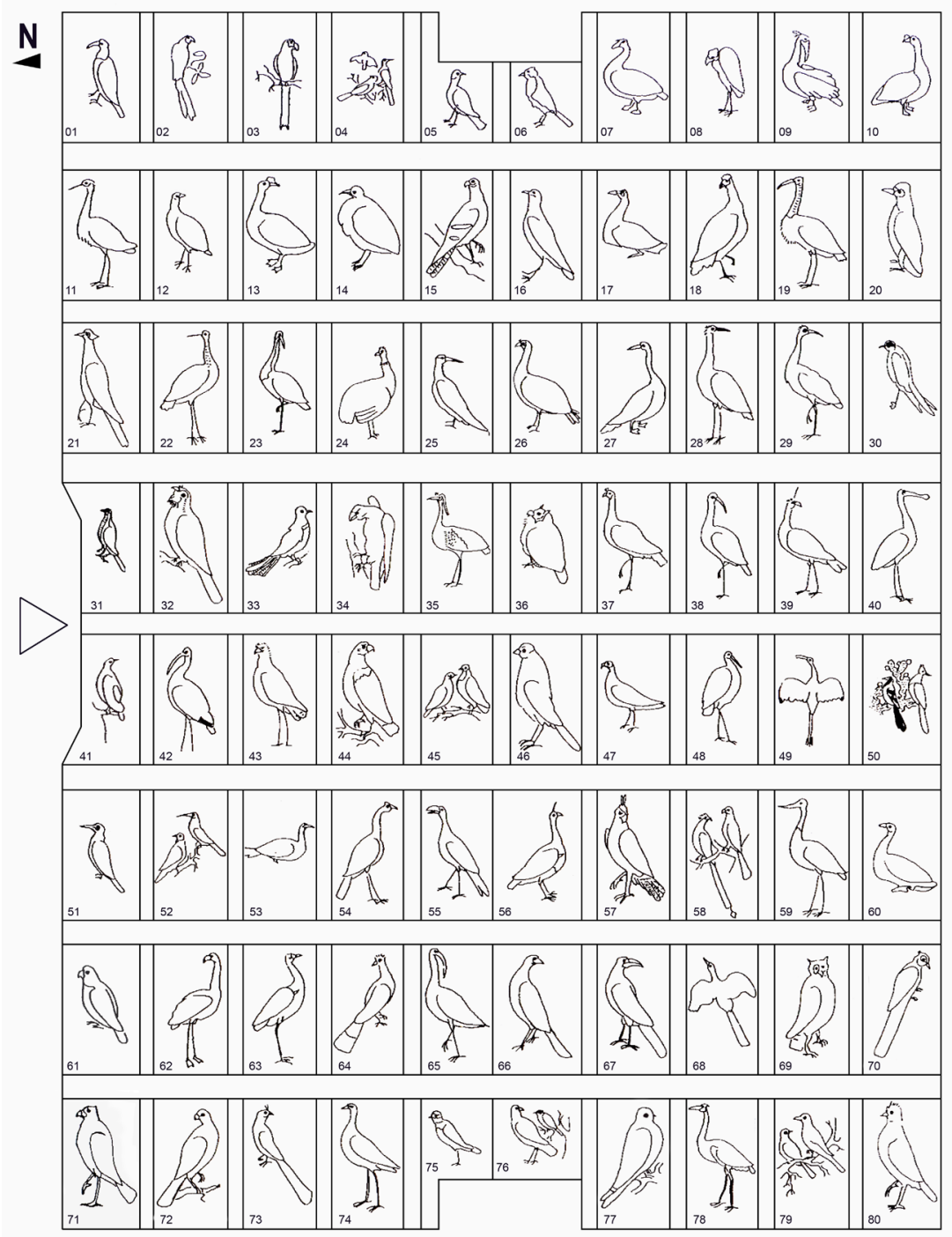

Figura 6. Desenho esquemático do teto do salão principal (em 1997). 


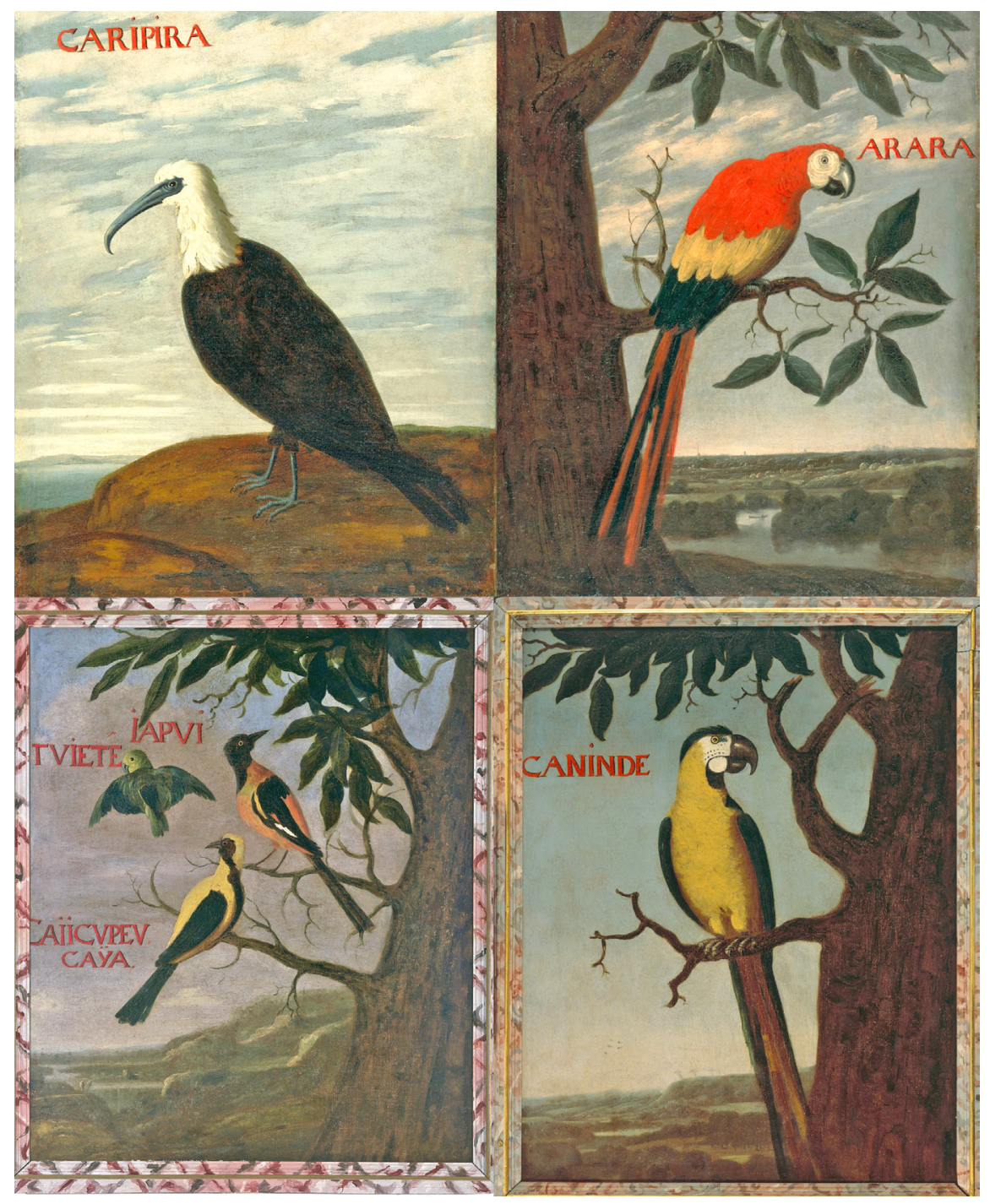

Figura 7. Os quadros de aves exóticas do salão principal de Hoflössnitz (da esquerda para a direita e de cima para baixo). Pintura 1: "Caripira" (Fregata magnificens). Pintura 2: "Arara" (Ara macao). Pintura 3: "Caninde" (Ara ararauna). Pintura 4: "Tuietê" (Forpus xanthopterygius), "Japui” (Icterus icterus) e "Caiicupeucaÿa" (Tangara cayana). 


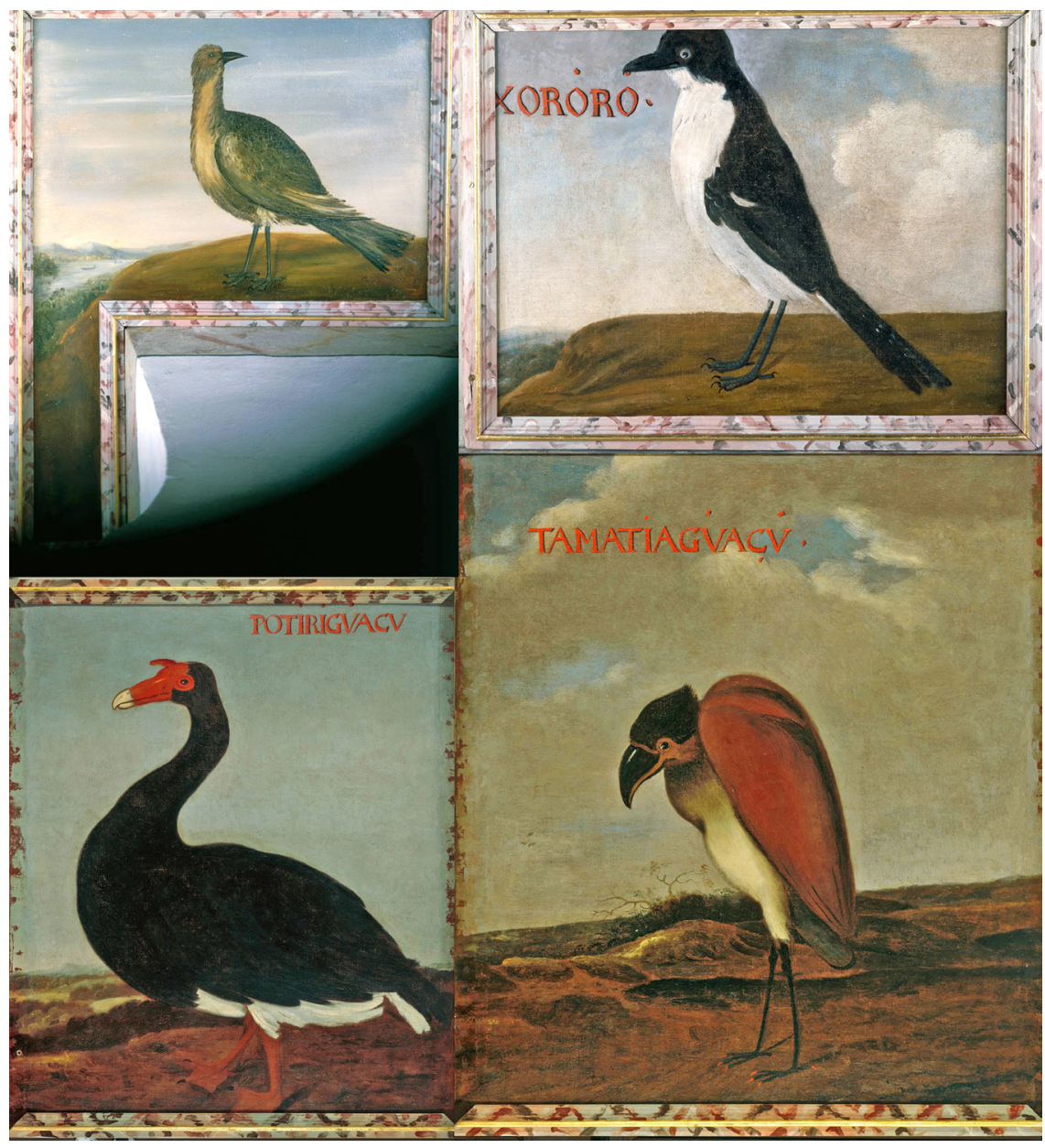

Figura 8. Os quadros de aves exóticas do salão principal de Hoflössnitz (da esquerda para a direita e de cima para baixo). Pintura 5: Anônima (Thraupis palmarum). Pintura 6: "Xoróró" (Taraba major). Pintura 7: "Potirigúaçu" (Cairina moschata). Pintura 8: "Tamatiagúaçú” (Cochlearius cochlearius). 


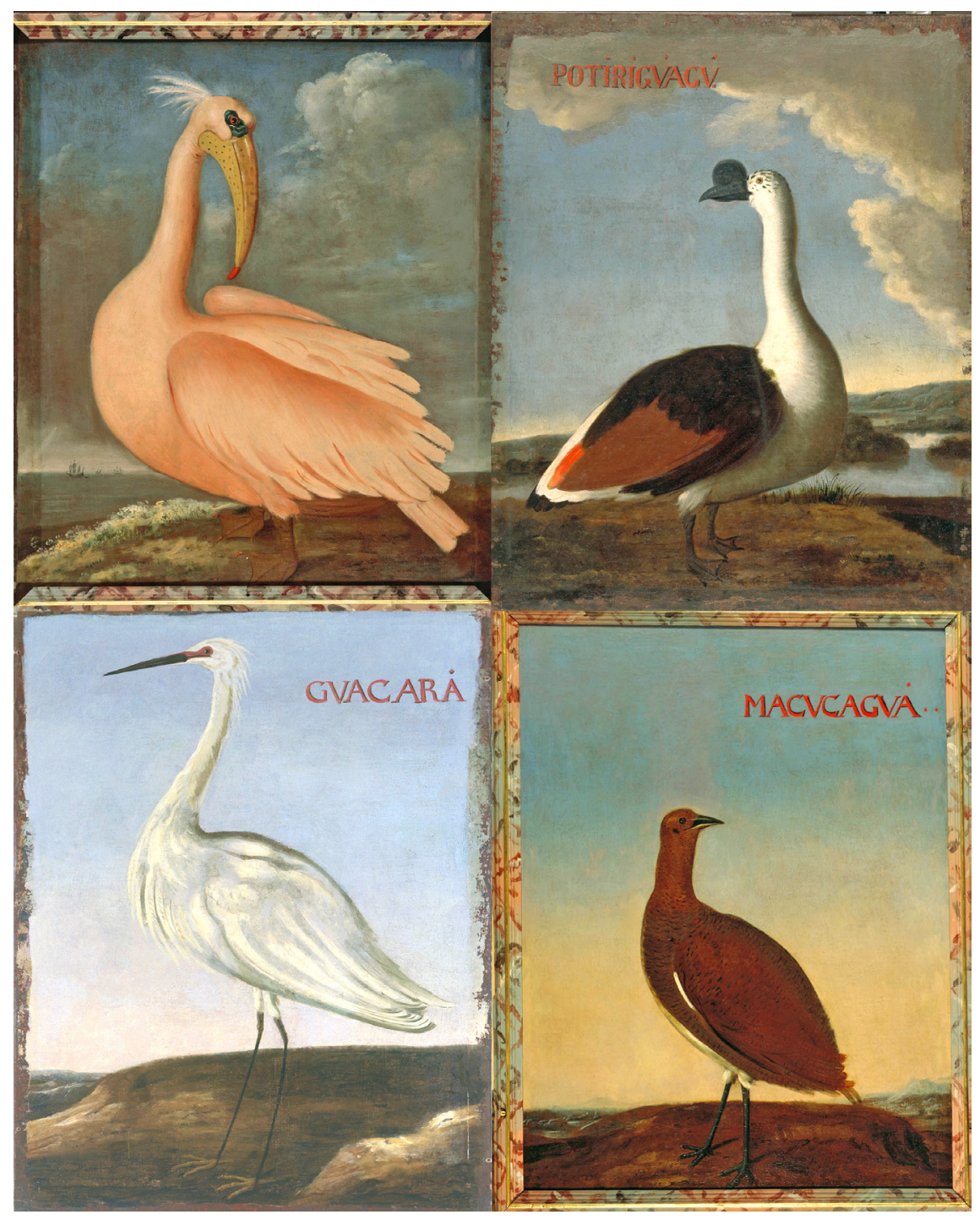

Figura 9. Os quadros de aves exóticas do salão principal de Hoflössnitz (da esquerda para a direita e de cima para baixo). Pintura 9: Anônima (Pelecanus rufescens). Pintura 10: "Potirigúacú" (Sarkidiornis melanotos). Pintura 11: "Guacará" (Egretta thula). Pintura 12: "Macucaguá" (Tinamus solitarius). 


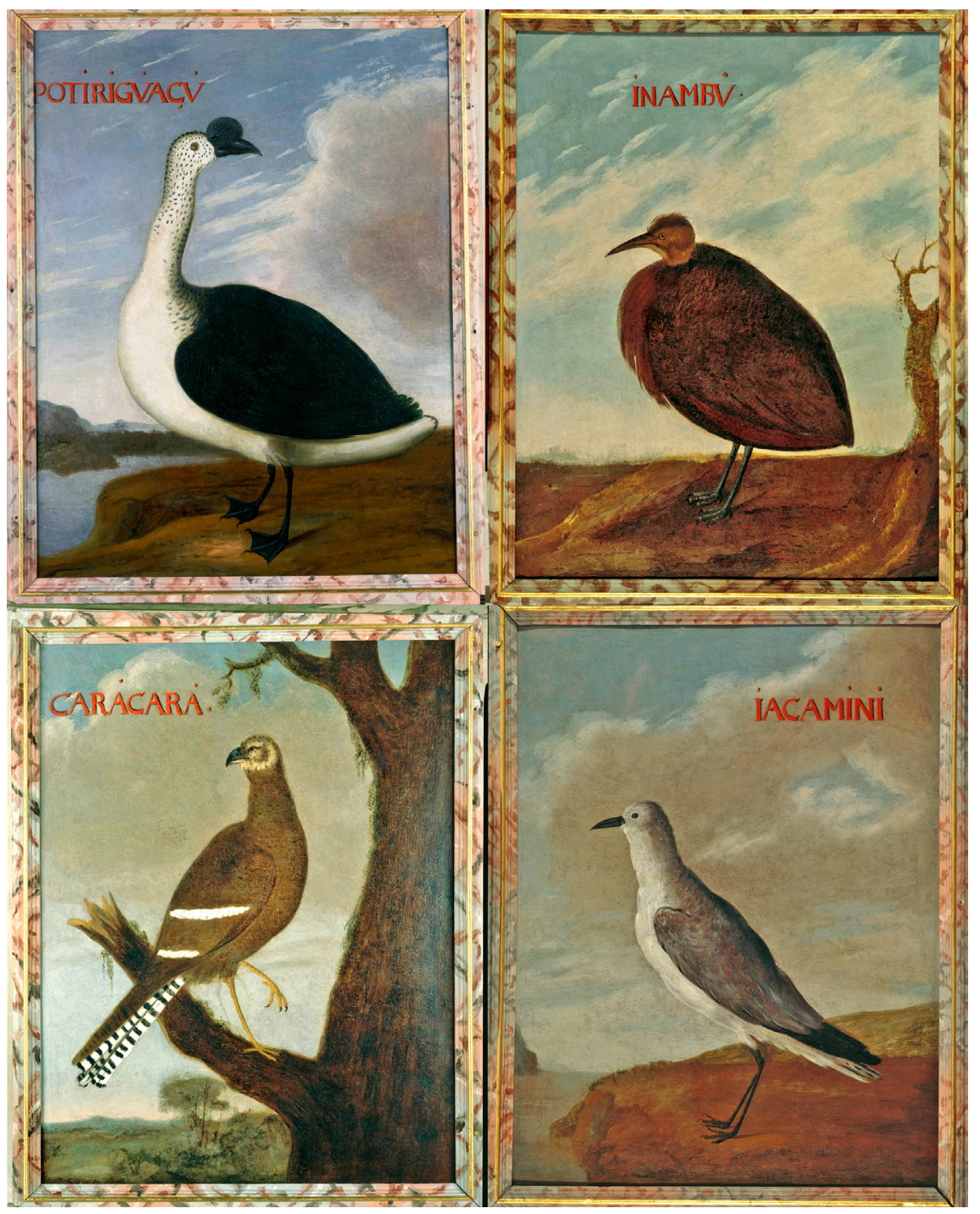

Figura 10. Os quadros de aves exóticas do salão principal de Hoflössnitz (da esquerda para a direita e de cima para baixo). Pintura 13: "Potirigúaçú" (Sarkidiornis melanotos). Pintura 14: "Inambú" (Rhynchotus rufescens). Pintura 15: "Carácará" (Falco brasiliensis). Pintura 16: "Jacamini” (Calidris alba). 


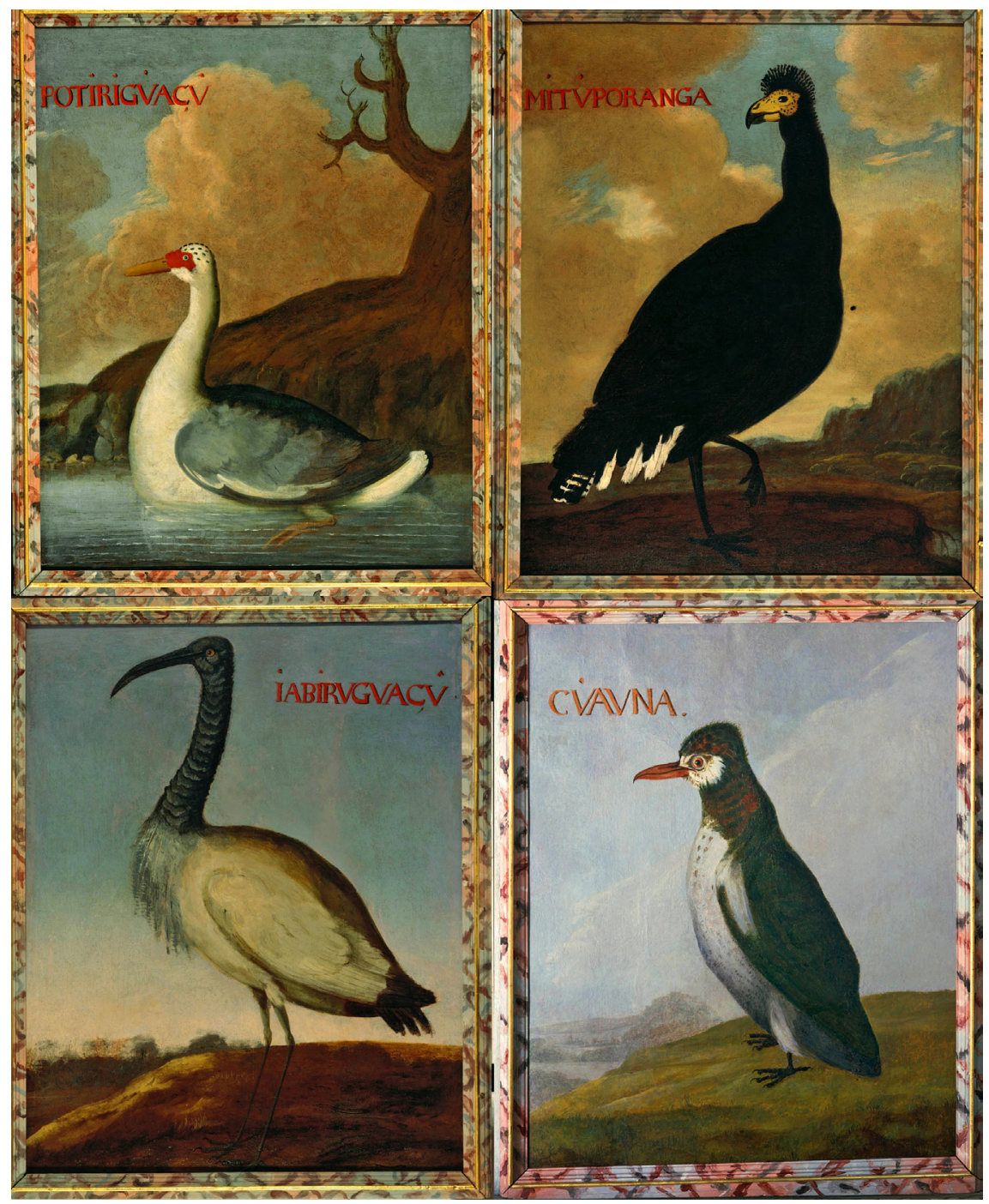

Figura 11. Os quadros de aves exóticas do salão principal de Hoflössnitz (da esquerda para a direita e de cima para baixo). Pintura 17: "Potirigúaçú" (Cairina moschata). Pintura 18: "Mitúporanga" (Crax cf. fasciolata). Pintura 19:

"Jabiruguaçú" (Mycteria americana). Pintura 20: "Cúauna” (Nystalus maculatus). 


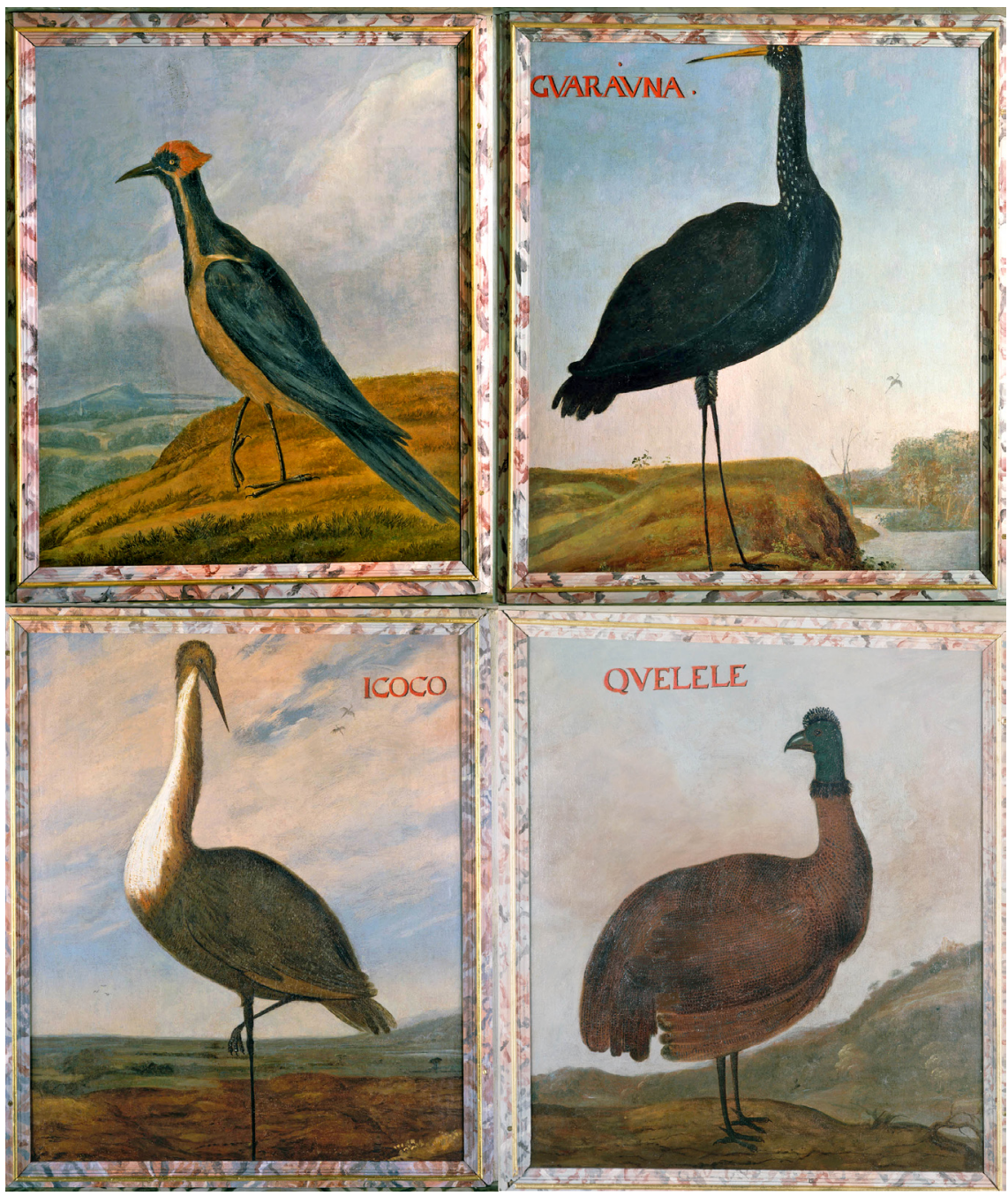

Figura 12. Os quadros de aves exóticas do salão principal de Hoflössnitz (da esquerda para a direita e de cima para baixo). Pintura 21: Anônima (Dryocopus lineatus). Pintura 22: "Guaráuna" (Aramus guarauna). Pintura 23: "Icoco" (Tigrisoma lineatum). Pintura 24: "Quelele" (Guttera pucherani). 


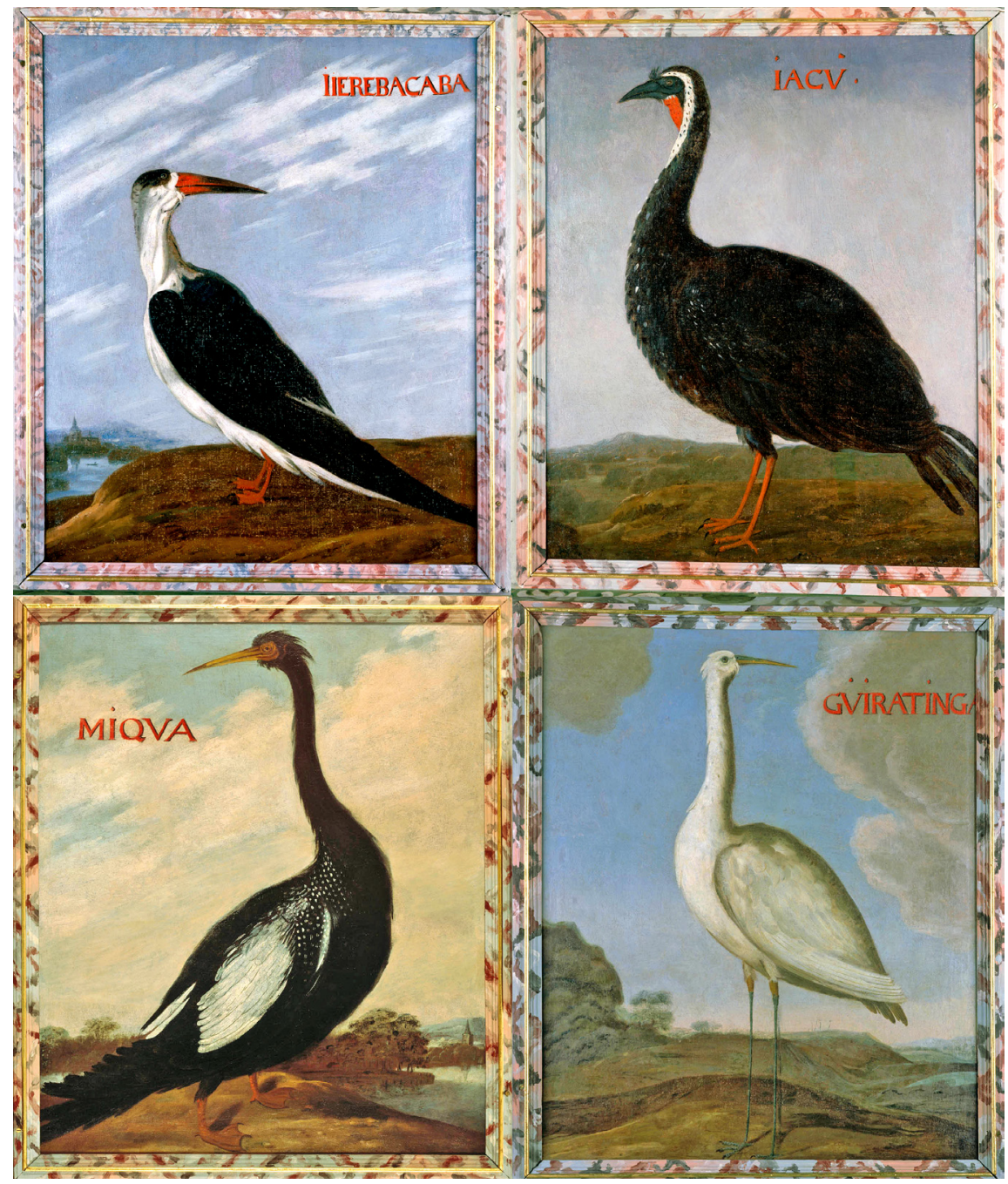

Figura 13. Os quadros de aves exóticas do salão principal de Hoflössnitz (da esquerda para a direita e de cima para baixo). Pintura 25: "Ijerebaçaba" (Rynchops nigra). Pintura 26: "Jacú" (Penelope jacucaca). Pintura 27: "Miqua" (Anhinga anhinga). Pintura 28: "Gúiratinga" (Casmerodius albus). 


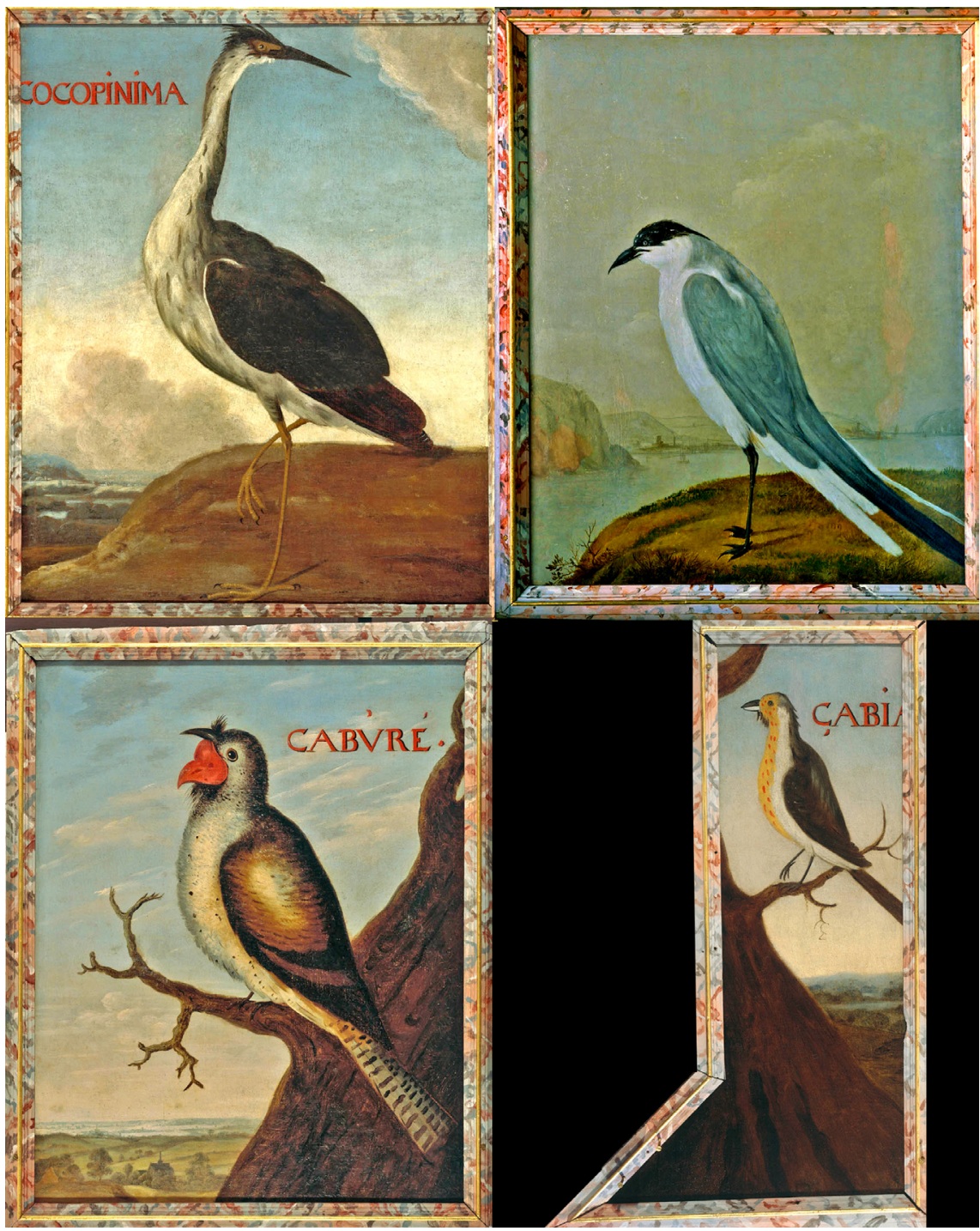

Figura 14. Os quadros de aves exóticas do salão principal de Hoflössnitz (da esquerda para a direita e de cima para baixo). Pintura 29: "Cocopinima" (Butorides striatus). Pintura 30: Anônima (Gelochelidon nilotica). Pintura 31: "Çabia" (Paroaria dominicana). Pintura 32: "Cabúré" (Nyctibius grandis). 


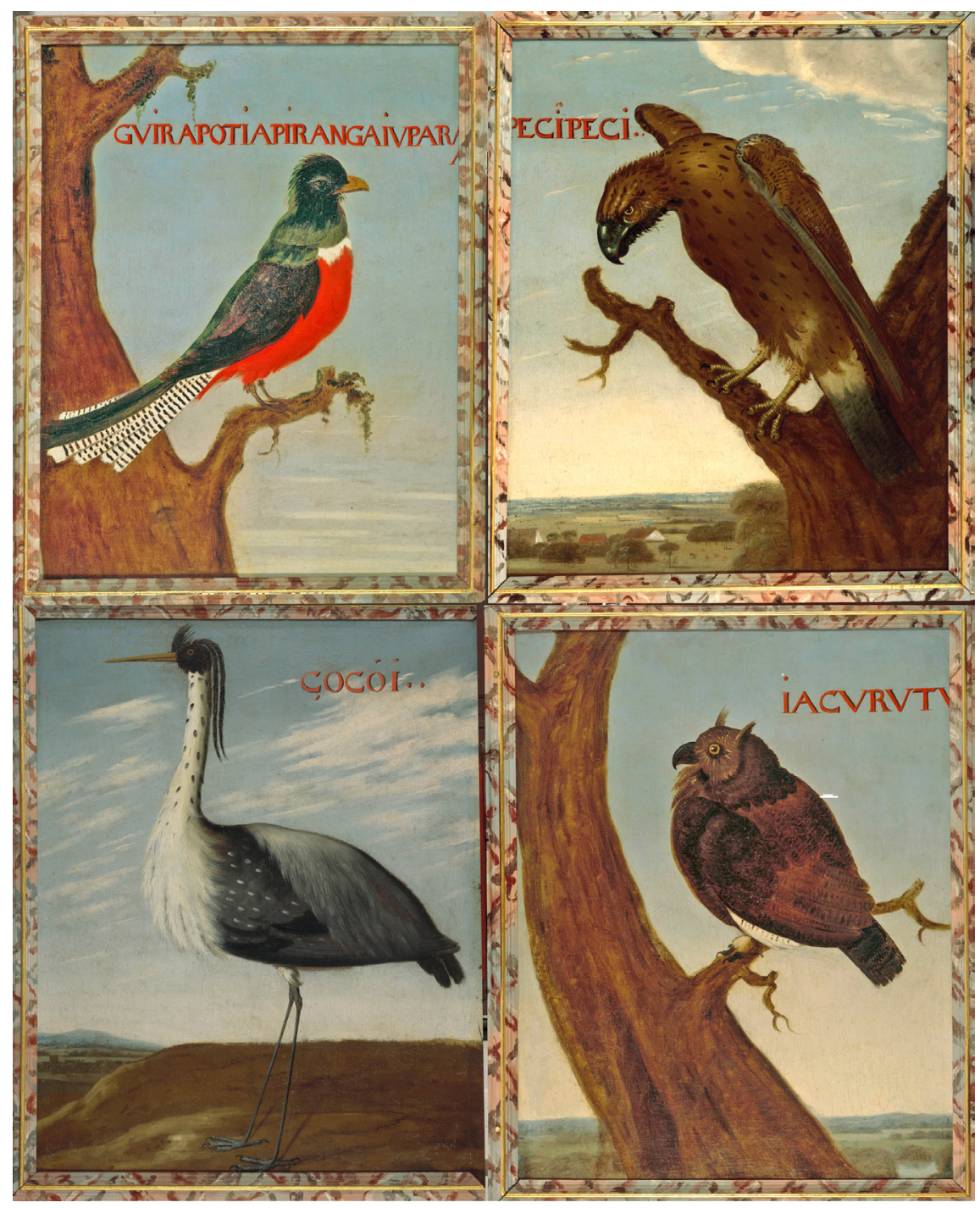

Figura 15. Os quadros de aves exóticas do salão principal de Hoflössnitz (da esquerda para a direita e de cima para baixo). Pintura 33: "Guirapotiapirangaiuparaba" (Trogon collaris). Pintura 34: "Pecîpeci” (Heterospizias meridionalis). Pintura 35: "Çocói” (Ardea cocoi). Pintura 36: "Jacurutu” (Bubo virginianus). 


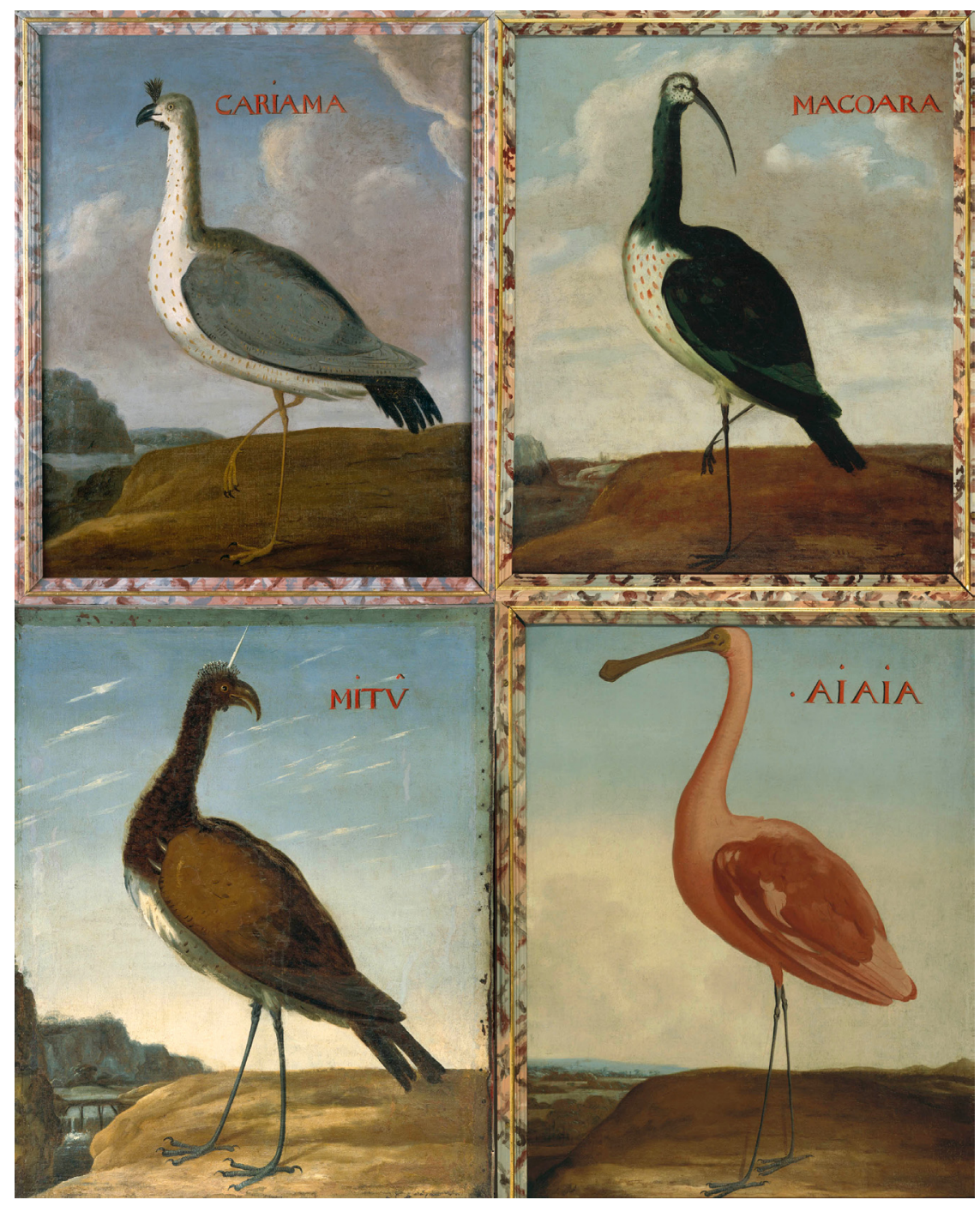

Figura 16. Os quadros de aves exóticas do salão principal de Hoflössnitz (da esquerda para a direita e de cima para baixo). Pintura 37: "Cariama” (Cariama cristata). Pintura 38: "Macoara" (ave paludícola não identificada). Pintura 39: "Mitû" (Anhima cornuta). Pintura 40: "Aiaia" (Ajaia ajaja). 


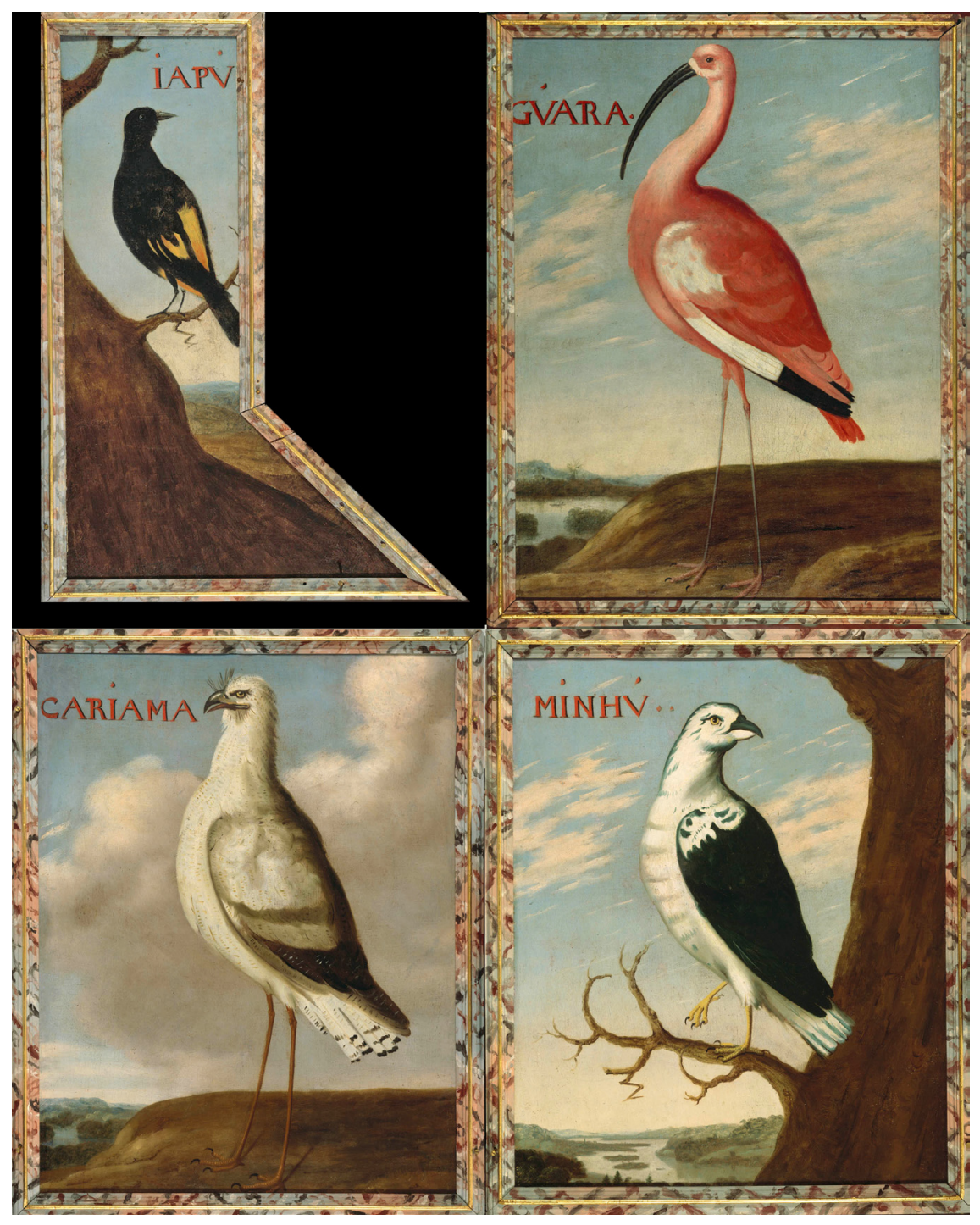

Figura 17. Os quadros de aves exóticas do salão principal de Hoflössnitz (da esquerda para a direita e de cima para baixo). Pintura 41: "Japú" (Cacicus cela). Pintura 42: "Gúara" (Eudocimus ruber). Pintura 43: "Cariama" (Cariama cristata). Pintura 44: "Minhú" (Leucopternis polionota). 


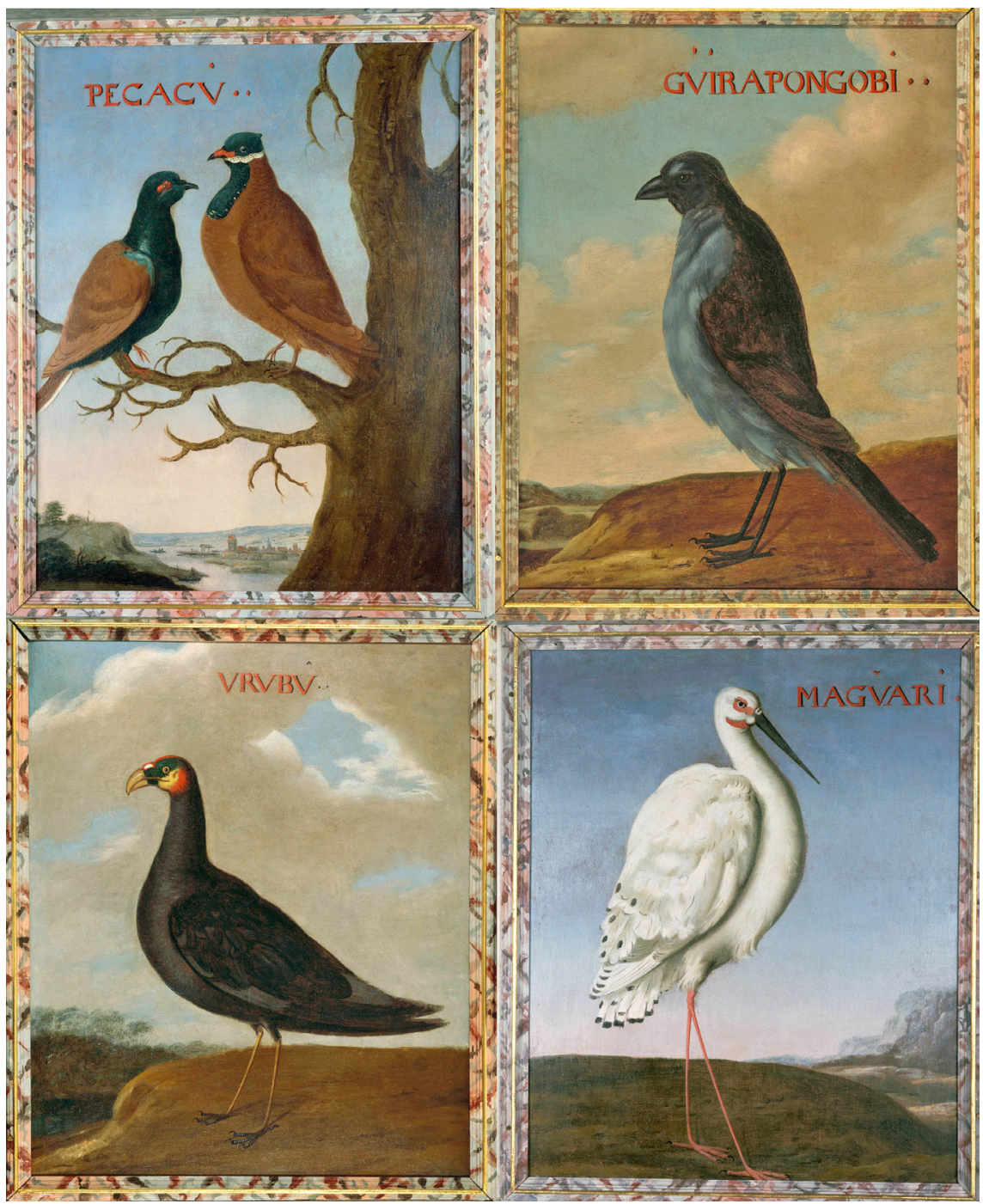

Figura 18. Os quadros de aves exóticas do salão principal de Hoflössnitz (da esquerda para a direita e de cima para baixo). Pintura 45: "Pecacú" (Treron sanctithomae e Starnoenas cyanocephala). Pintura 46: "Gúirapongobi" (Saltator maximus). Pintura 47: "Urubû" (Cathartes burrovianus). Pintura 48: "Magúari" (Euxenura maguari). 


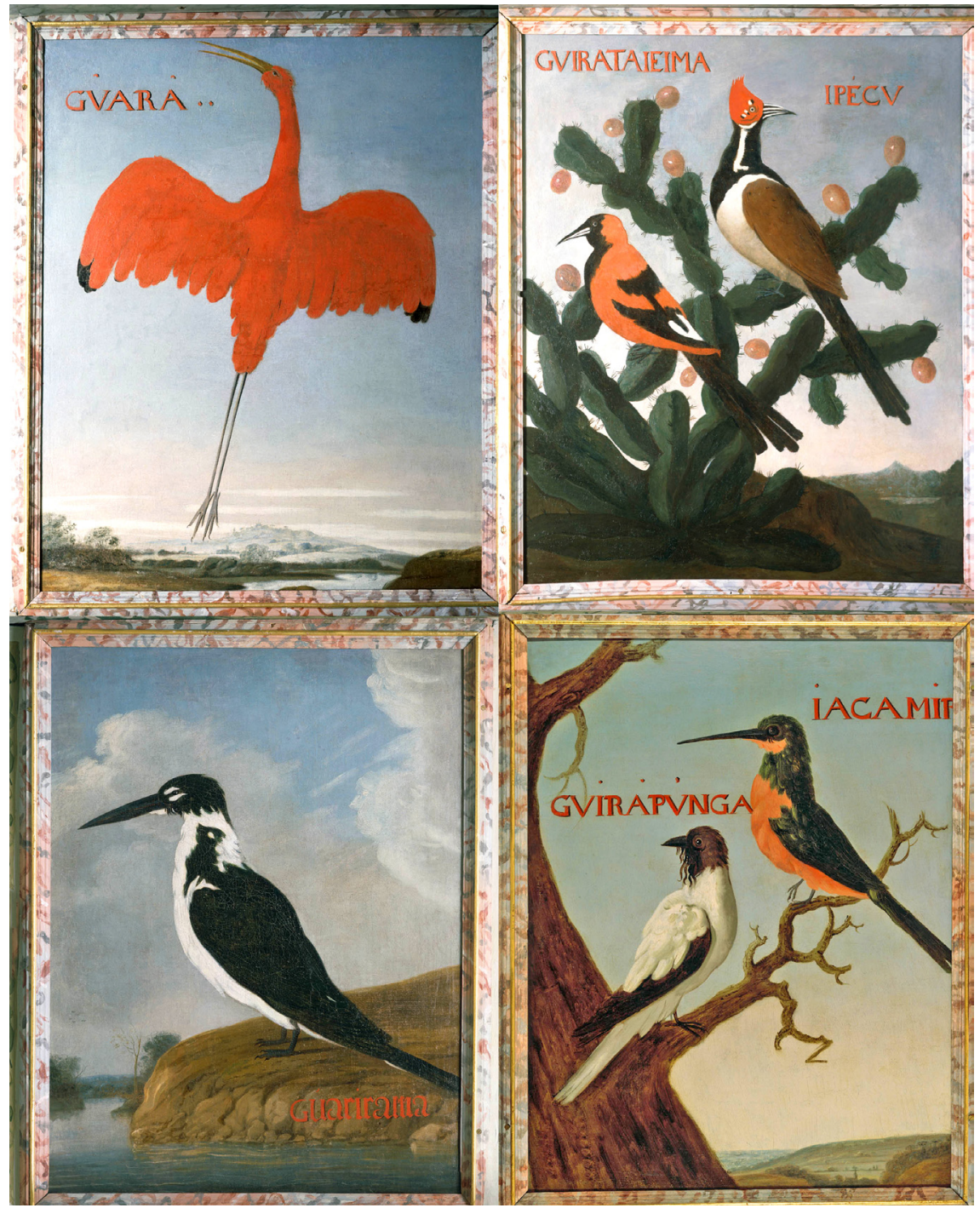

Figura 19. Os quadros de aves exóticas do salão principal de Hoflössnitz (da esquerda para a direita e de cima para baixo). Pintura 49: "Gúará" (Eudocimus ruber). Pintura 50: "Guiratajeima" (Icterus icterus) e "Ipécu” (Phloeoceastes melanoleucos). Pintura 51: "Gúarirama" (Chloroceryle amazona). Pintura 52: “Guirápúnga” (Procnias averano) e "Jacamiri” (Galbula ruficauda). 


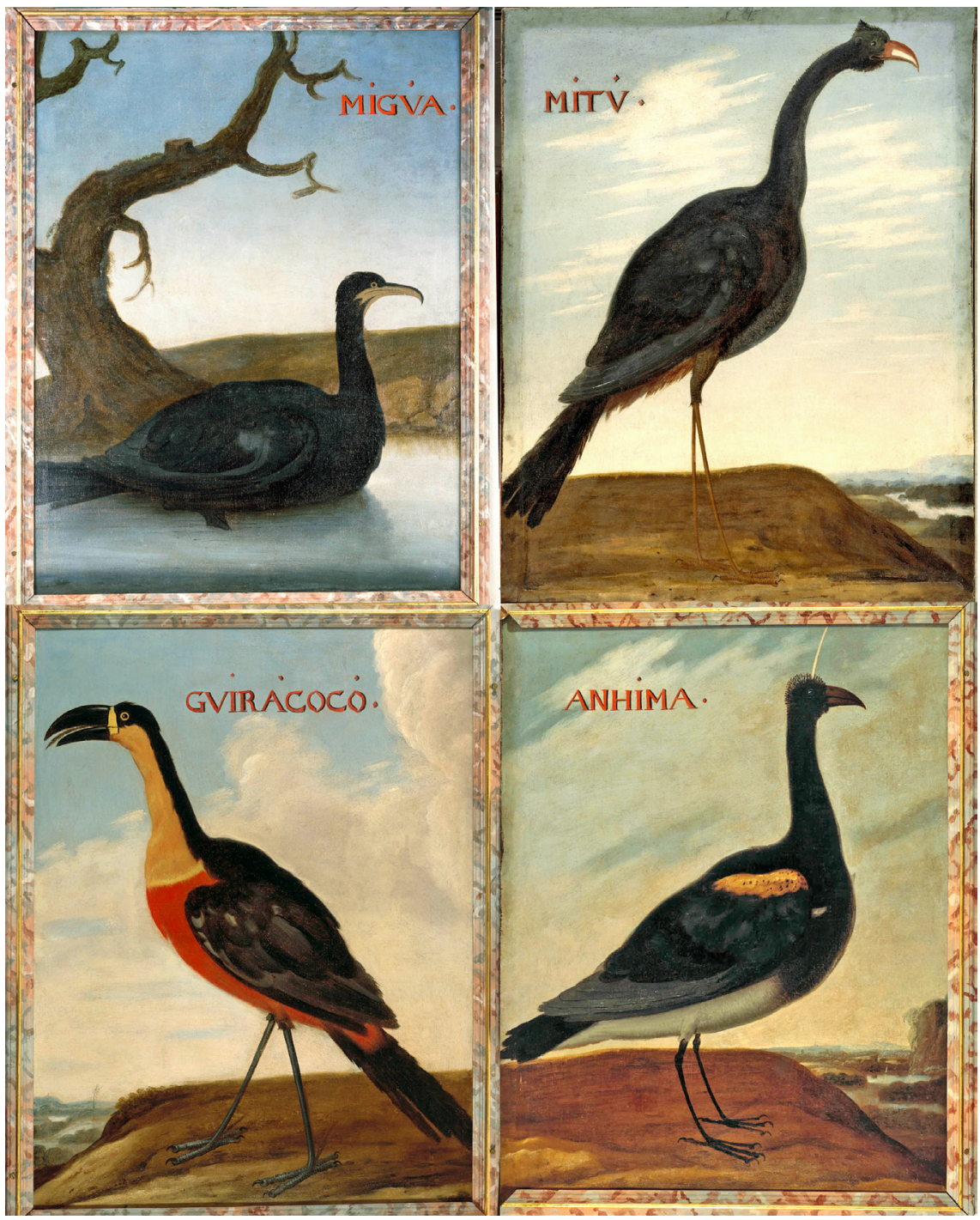

Figura 20. Os quadros de aves exóticas do salão principal de Hoflössnitz (da esquerda para a direita e de cima para baixo). Pintura 53: "Migúa” (Phalacrocorax brasilianus). Pintura 54: "Mitú" (Mitu mitu). Pintura 55: "Guirácocó" (Ramphastos vitellinus ariel). Pintura 56: "Anhima” (Anhima cornuta). 


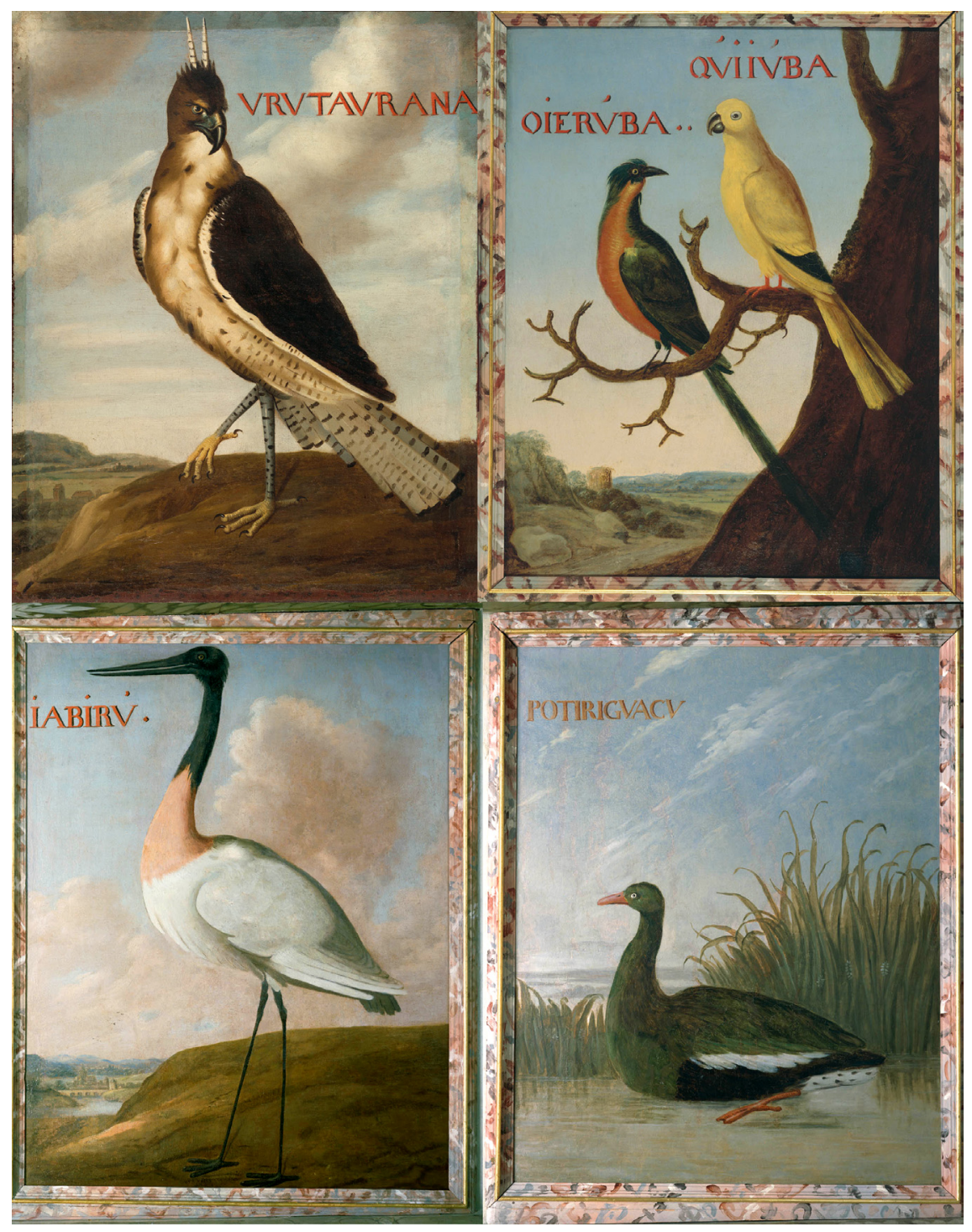

Figura 21. Os quadros de aves exóticas do salão principal de Hoflössnitz (da esquerda para a direita e de cima para baixo). Pintura 57: "Urutaurana" (Spizaetus ornatus). Pintura 58: "Ojerúba" (Momotus momota) e "Qúijúba” (Aratinga guarouba). Pintura 59: "Jabirú” (Jabiru mycteria). Pintura 60: "Potiriguacu" (Dendrocygna autumnalis). 


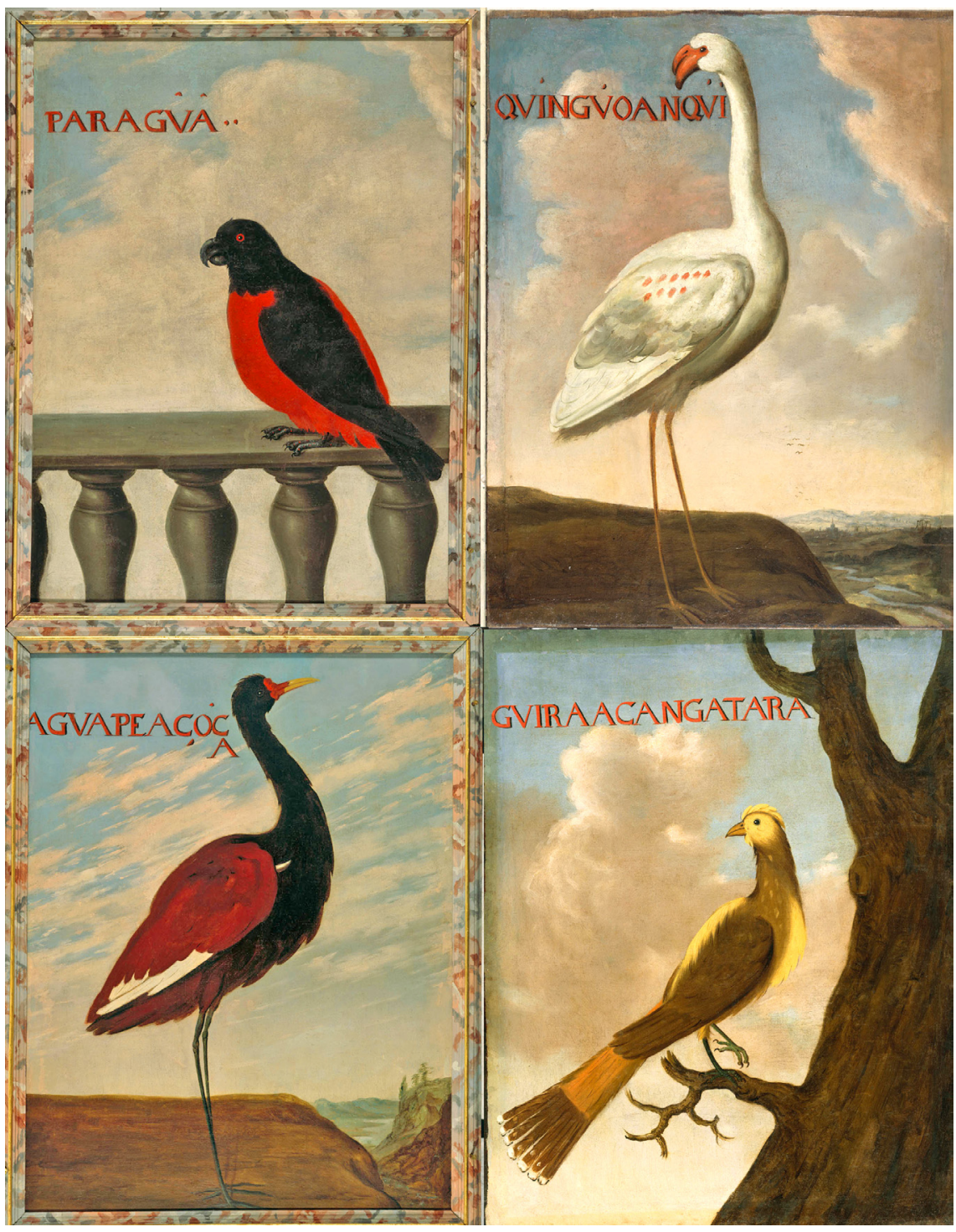

Figura 22. Os quadros de aves exóticas do salão principal de Hoflössnitz (da esquerda para a direita e de cima para baixo). Pintura 61: "Paragûâ" (Psittacus paraguanus). Pintura 62: "Quingúoanqúi" (Phoenicopterus ruber roseus). Pintura 63: "Aguapeaçóca” (Jacana jacana). Pintura 64: "Guiraacangatara” (Guira guira). 


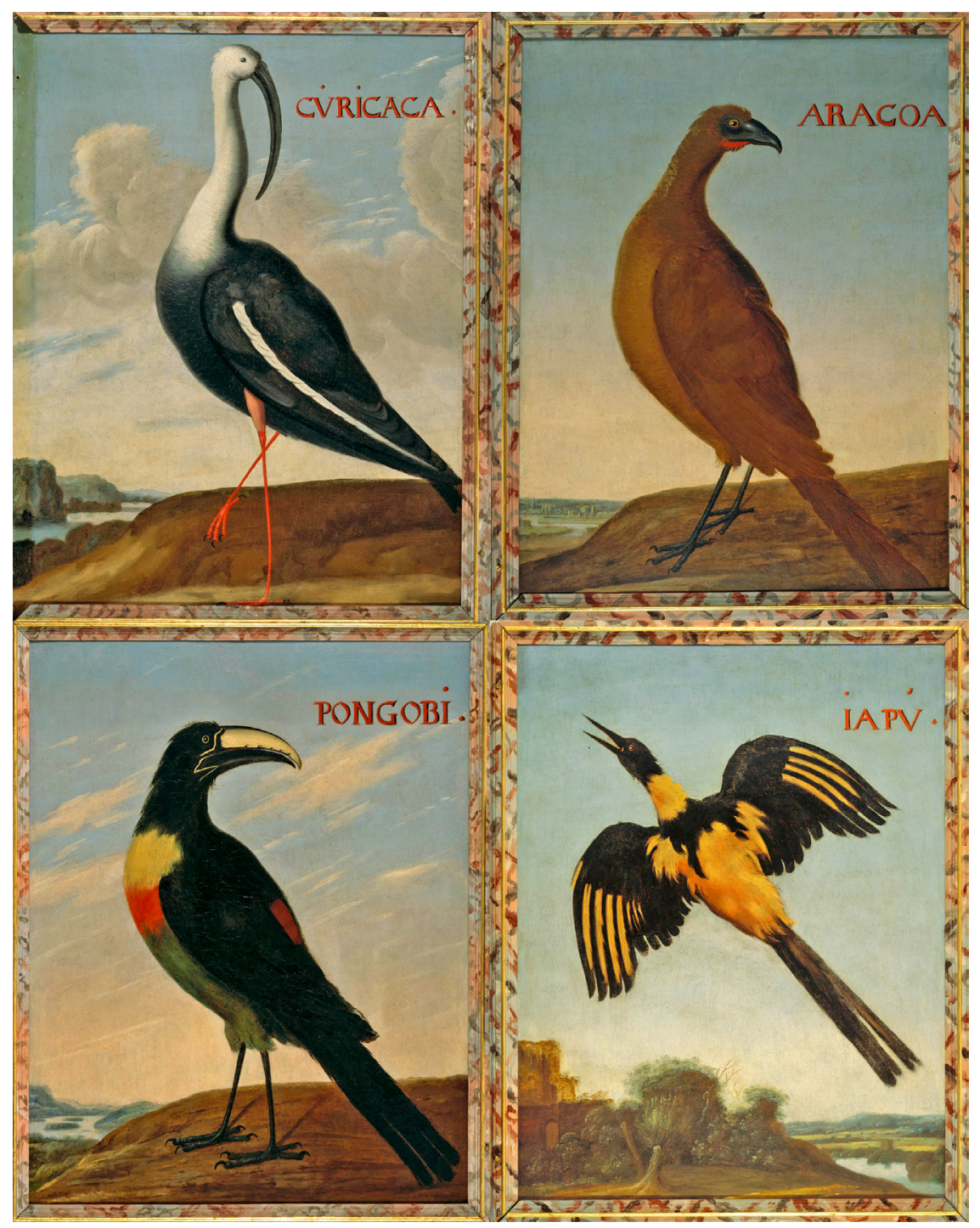

Figura 23. Os quadros de aves exóticas do salão principal de Hoflössnitz (da esquerda para a direita e de cima para baixo). Pintura 65: "Cúricaca" (Theristicus caudatus). Pintura 66: "Aracoa” (Ortalis guttata araucuan). Pintura 67: "Pongobi” (Pteroglossus aracari). Pintura 68: "Japú” (Icterus icterus). 


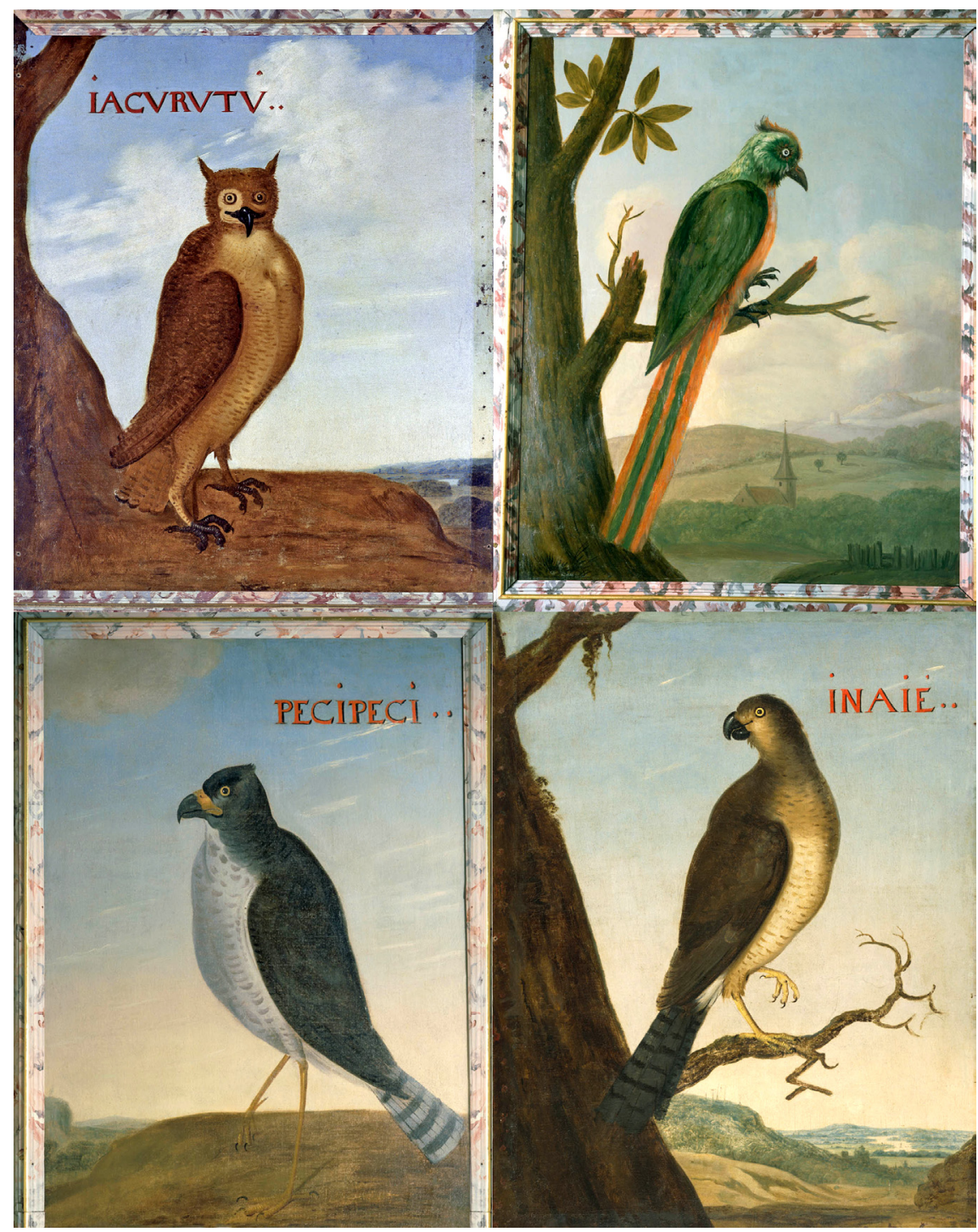

Figura 24. Os quadros de aves exóticas do salão principal de Hoflössnitz (da esquerda para a direita e de cima para baixo). Pintura 69: "Jacurutú" (Bubo virginianus). Pintura 70: Anônima (talvez Momotus momota). Pintura 71: "Pecipeci" (Buteo magnirostris). Pintura 72: "Inaié" (Accipiter erythronemius). 


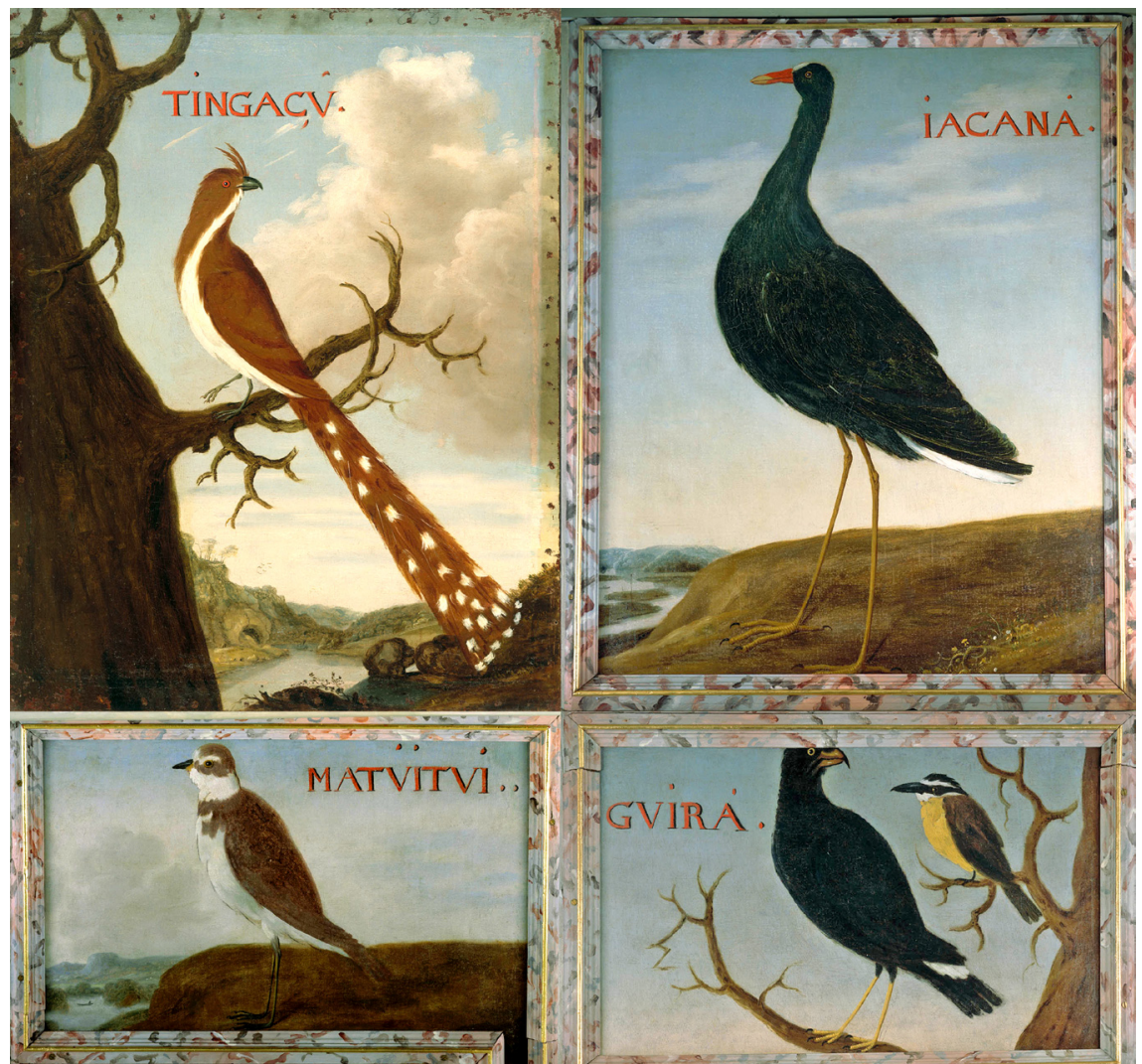

Figura 25. Os quadros de aves exóticas do salão principal de Hoflössnitz (da esquerda para a direita e de cima para baixo). Pintura 73: "Tingaçú" (Piaya cayana). Pintura 74: "Jacaná" (Porphyrula martinica). Pintura 75: "Matúitui” (Charadrius semipalmatus). Pintura 76: "Guirá” (Buteogallus urubitinga e Megarhynchus pitangua). 


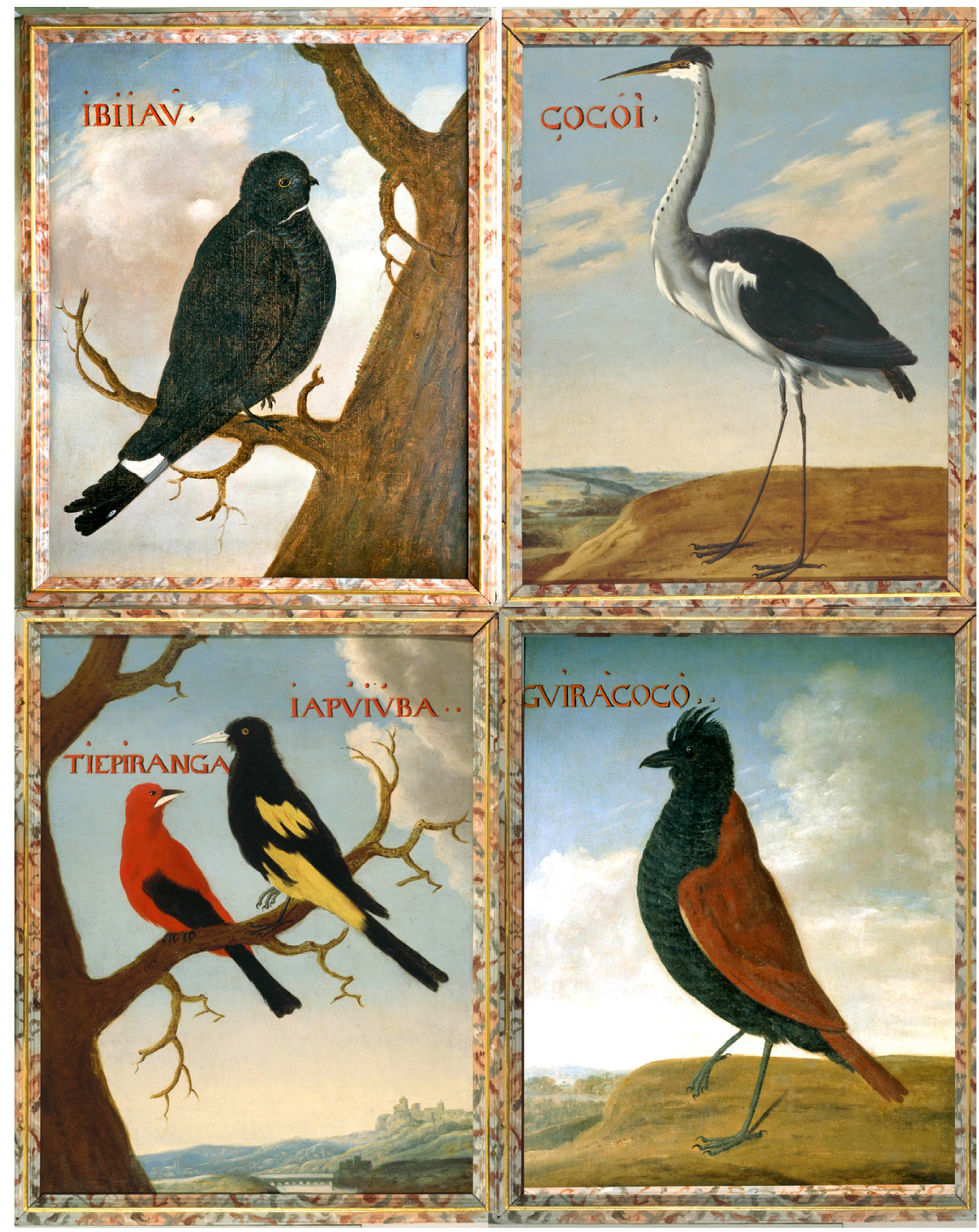

Figura 26. Os quadros de aves exóticas do salão principal de Hoflössnitz (da esquerda para a direita e de cima para baixo). Pintura 77: "Ibijaû" (Chordeiles acutipennis). Pintura 78: "Çocói” (Ardea cocoi). Pintura 79: "Tiepiranga" (Ramphocellus bresilius) e "Japújúba” (Cacicus cela). Pintura 80: "Guirácocó” (Thamnophilus palliatus). 


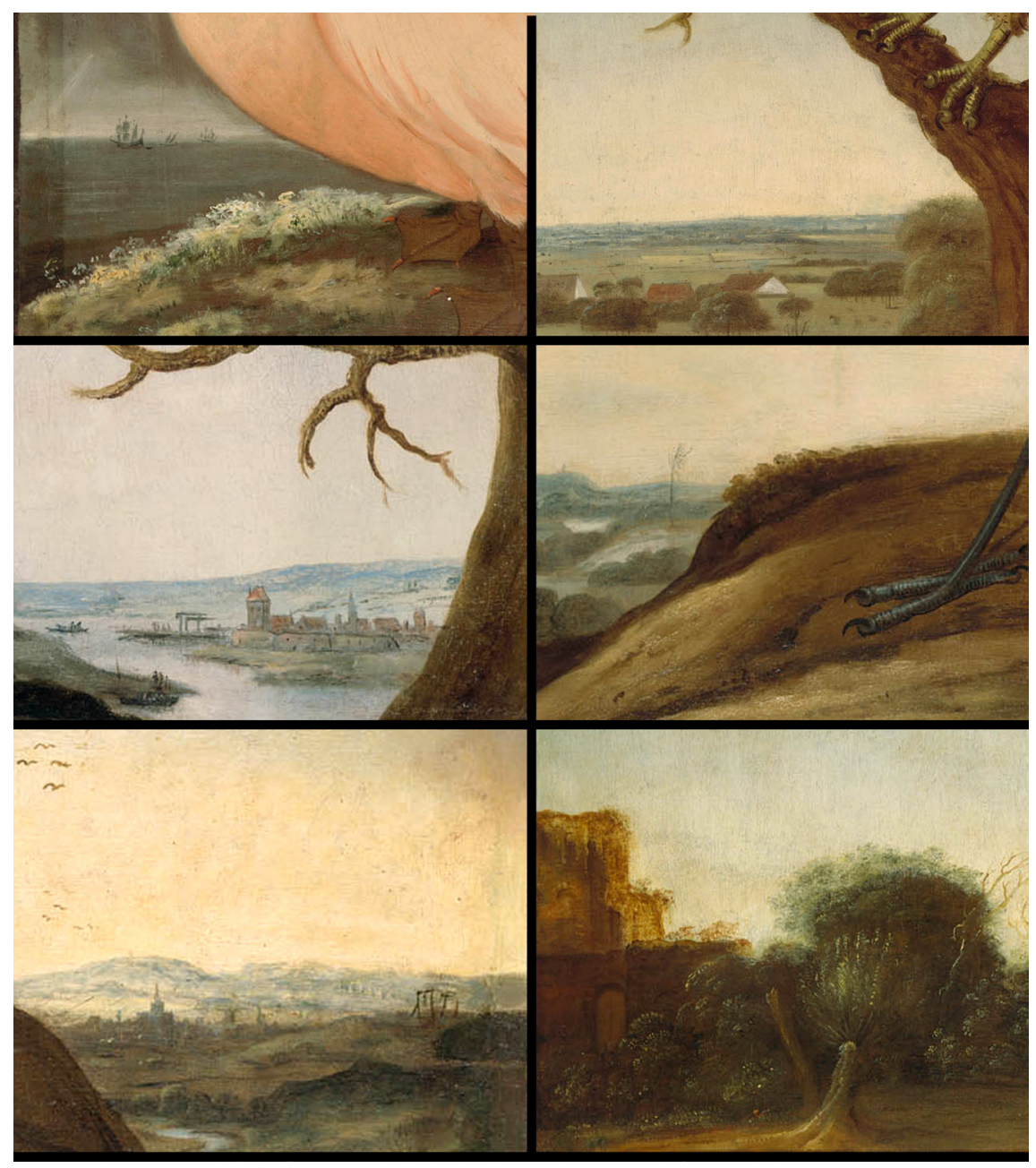

Figura 27. Exemplos das paisagens de fundo encontradas nos quadros de Hoflössnitz. Os detalhes mostram uma marinha (pintura 9), uma cena rural (pintura 34), uma cidade ribeirinha (pintura 45), a indistinta silhueta de uma palmeira (pintura 55 ), uma cidade com seu patíbulo (pintura 62) e ruínas cobertas por vegetação (pintura 68) 


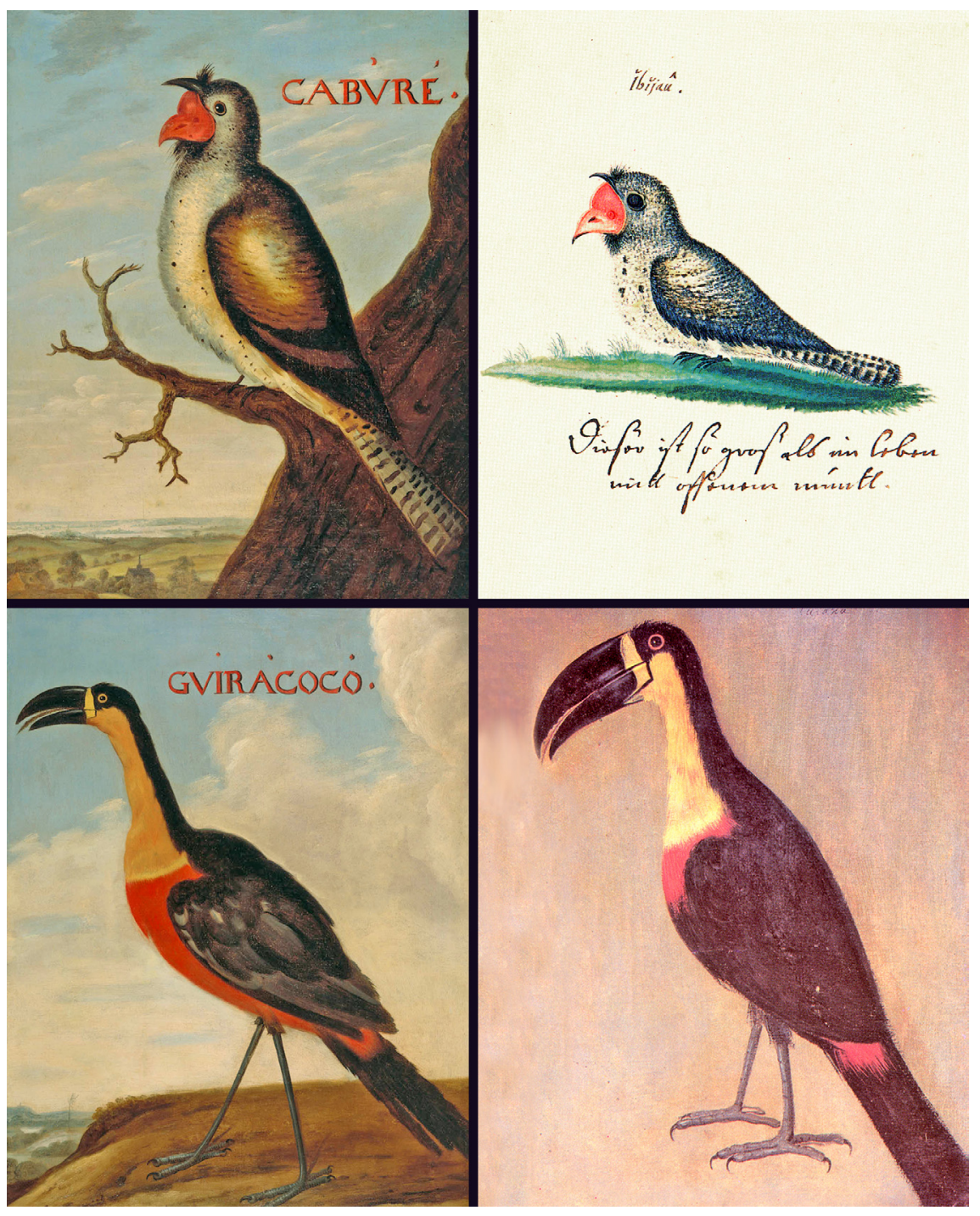

Figura 28. Os quadros do "cabúré" e do "guirácocó" (pinturas 32 e 55) comparados às ilustrações do "íbijaû" (Nyctibius grandis) e do "tucana” (Ramphastos vitellinus ariel) dos Libri Principis e das Icones Volatilium. 


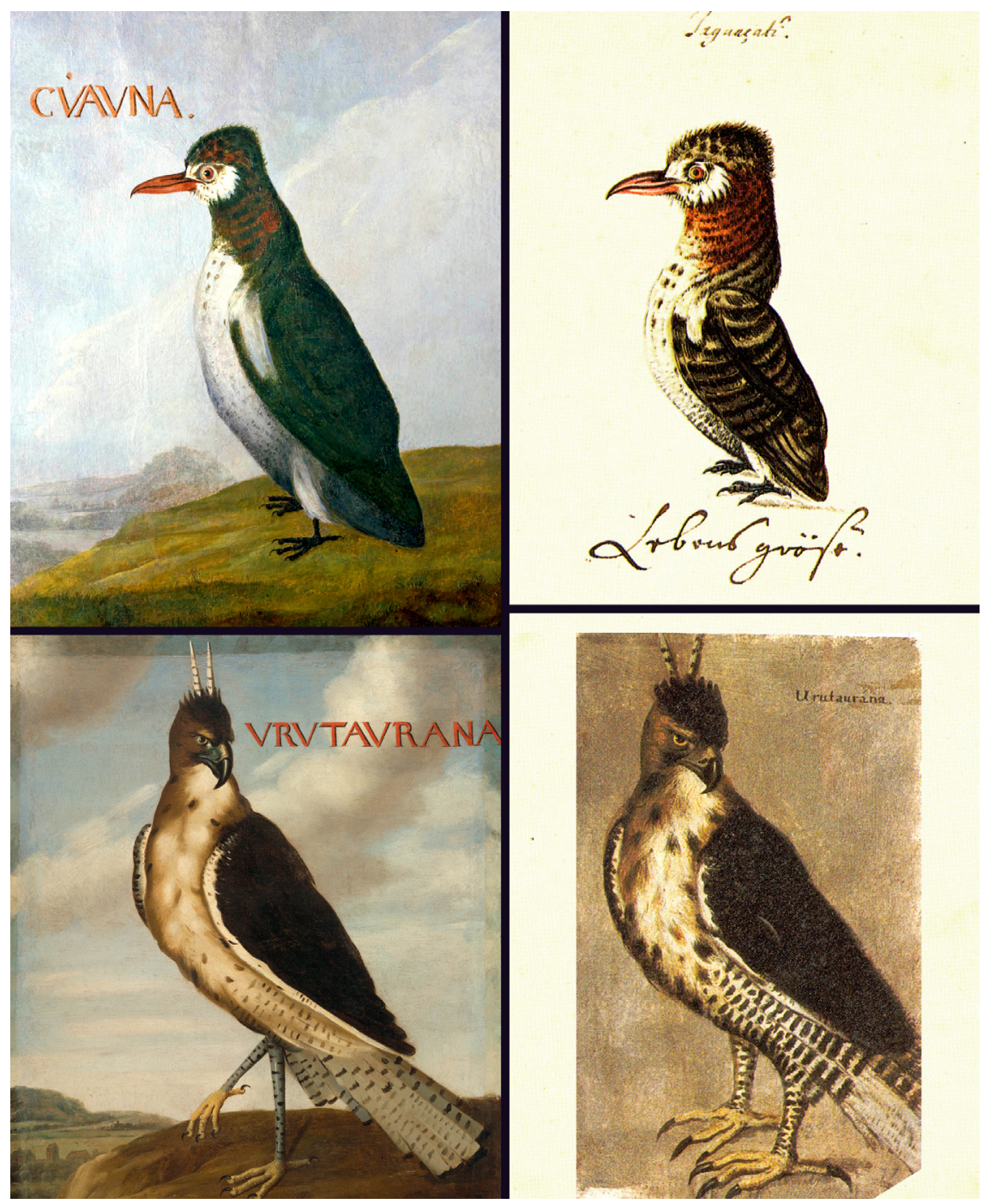

Figura 29. Os quadros do "cúauna" e do "urutaurana" (pinturas 20 e 57) comparados às ilustrações do "jaguaçatî" (Nystalus maculatus) e do "urutaurána” (Spizaetus ornatus) dos Libri Principis e das Icones Volatilium. 


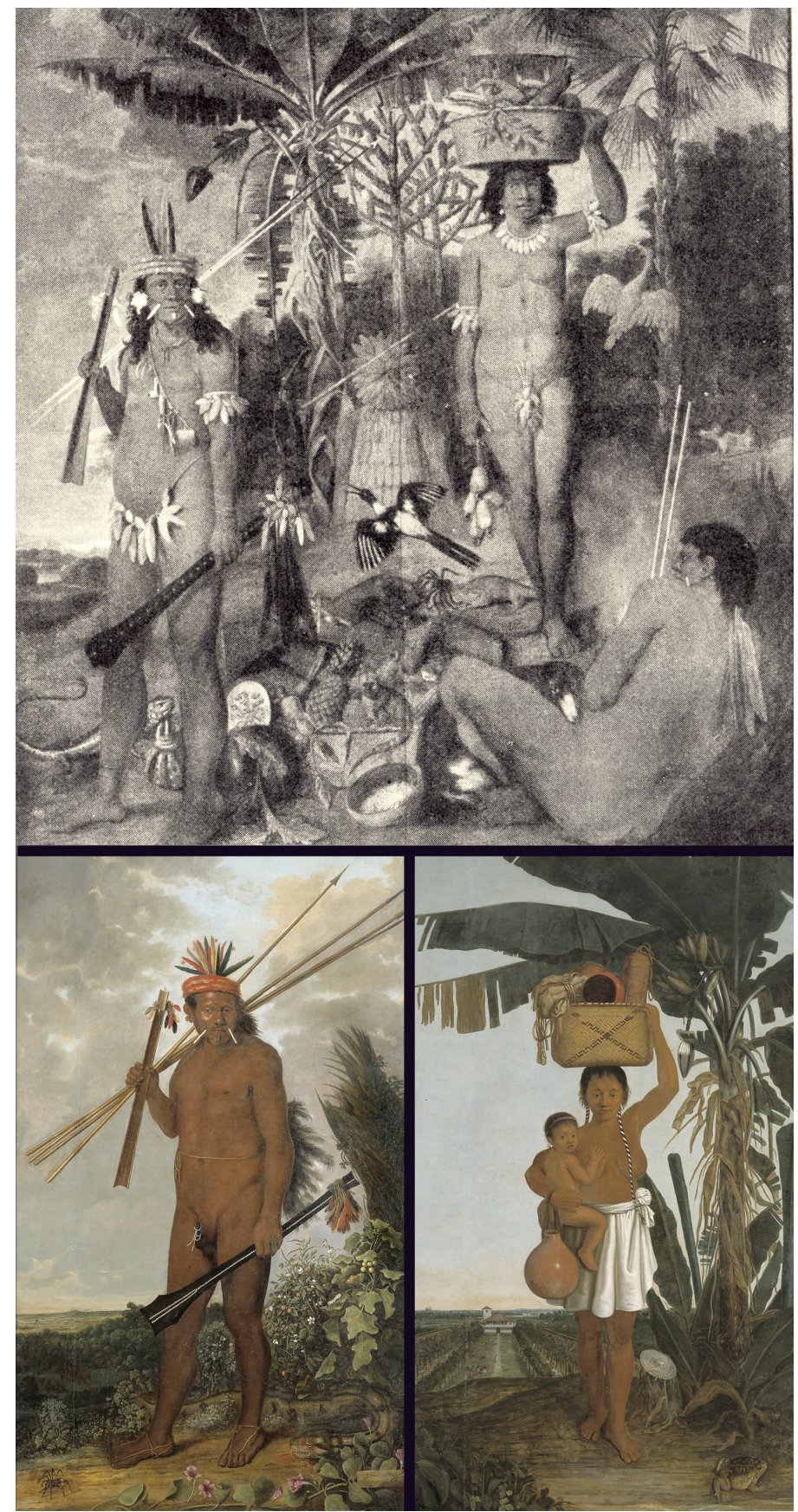

Figura 30. A desaparecida pintura do Castelo de Pretzch dedicada aos índios brasileiros e os quadros do "Homem Tapuia" e da "Mulher Tupi" pertencentes ao Nationalmuseet de Copenhague. 


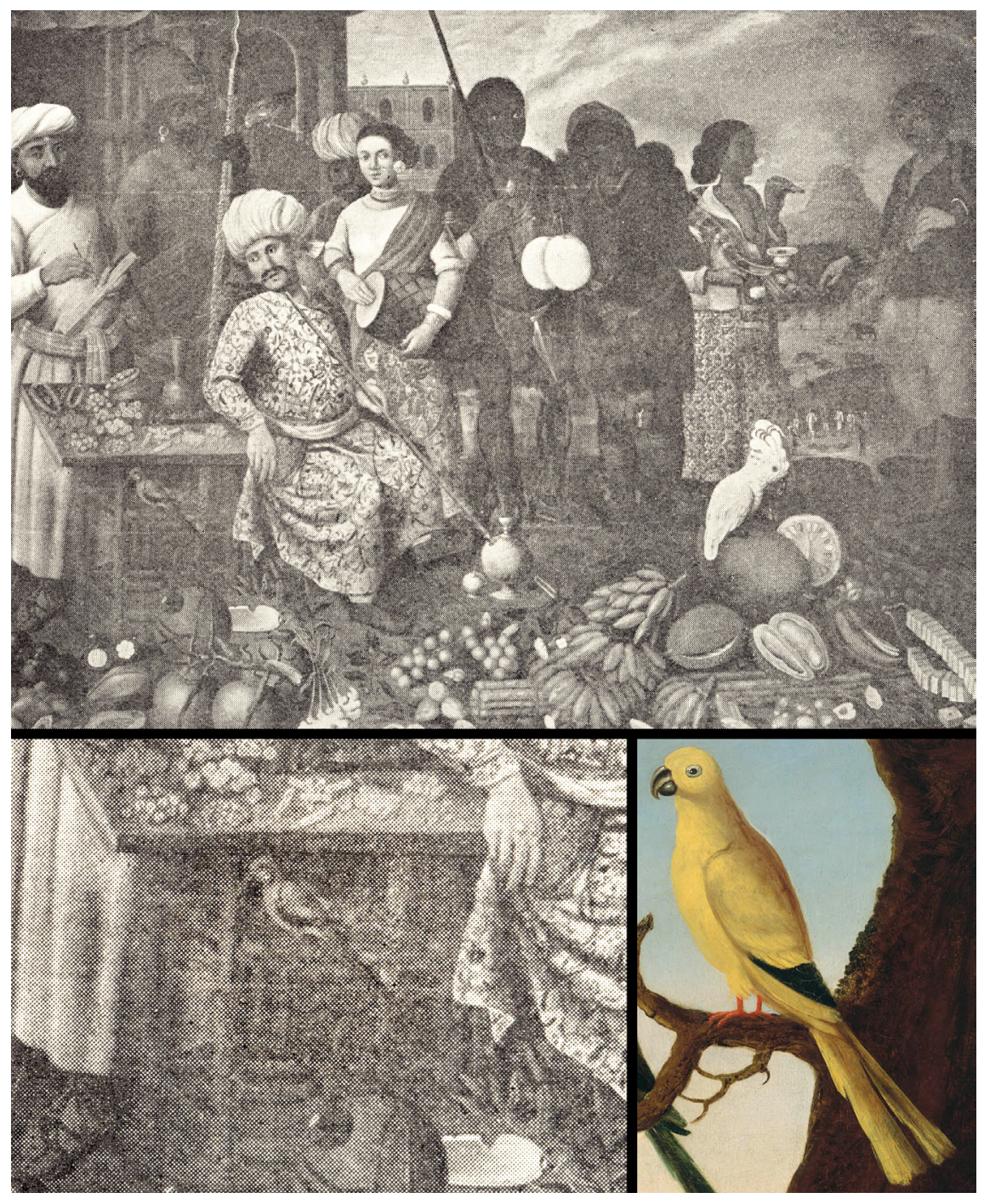

Figura 31. A desaparecida pintura do Castelo de Pretzch dedicada aos habitantes do Oriente Próximo e o quadro da "qúijúba" (Aratinga guarouba) de Hoflössnitz (pintura 58). 


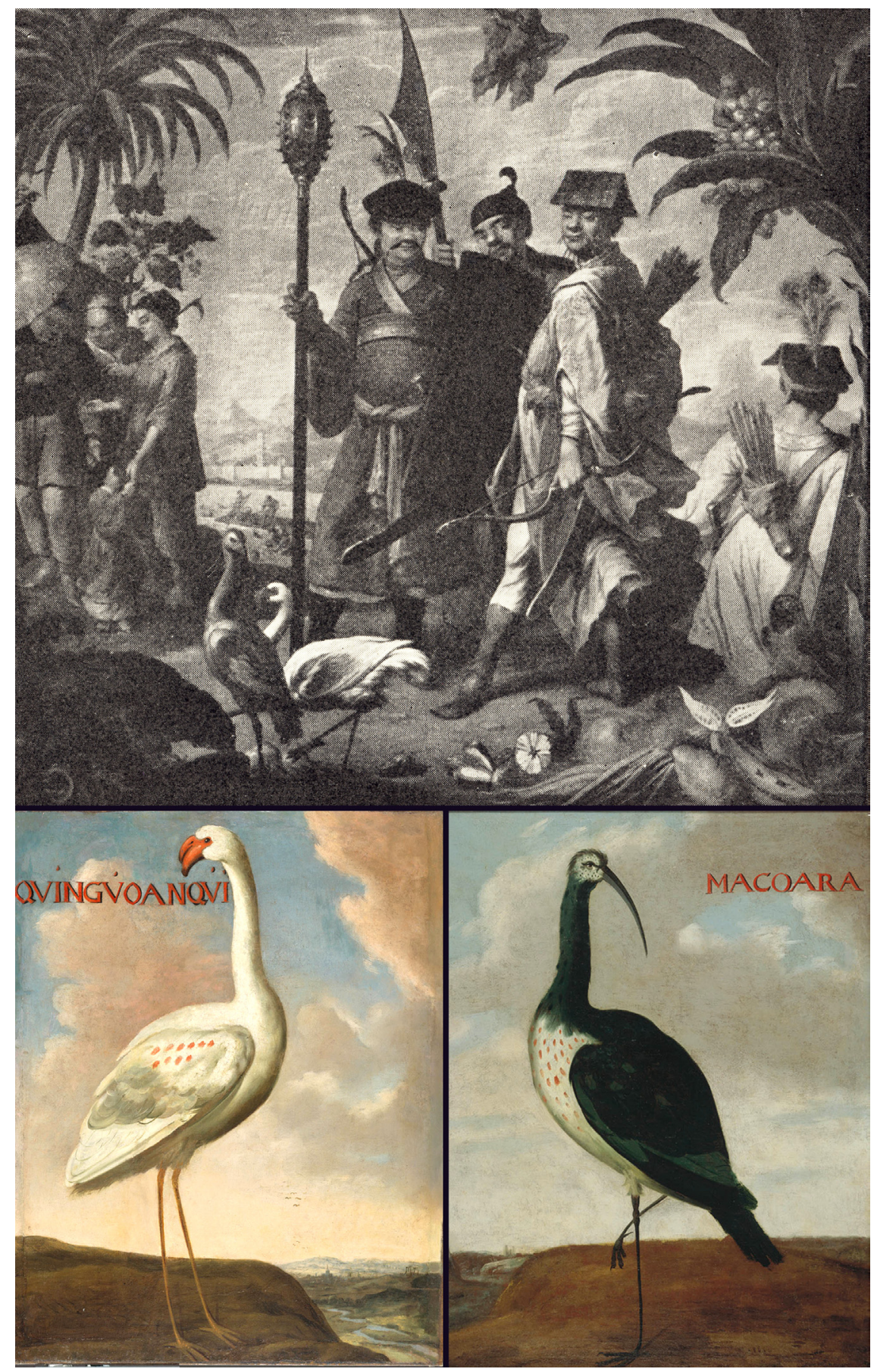

Figura 32. A desaparecida pintura do Castelo de Pretzch dedicada aos habitantes do Oriente Distante e os quadros do "macoara" (ave paludícola não identificada) e do “quingúoanqúi” (Phoenicopterus ruber roseus) de Hoflössnitz (pinturas 58 e 62). 


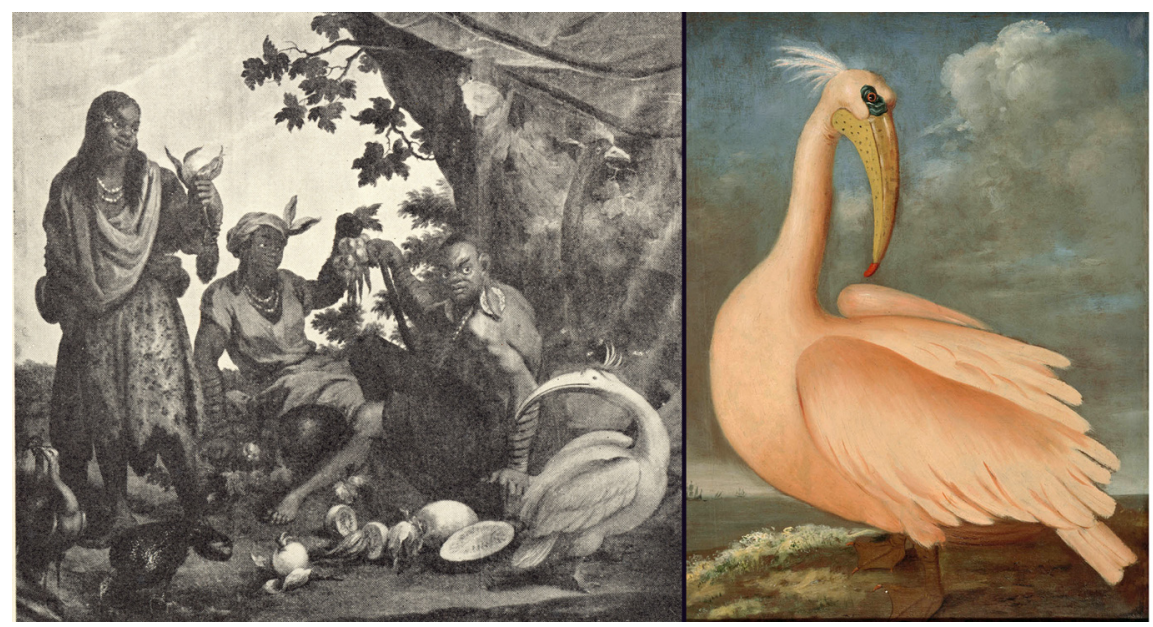

Figura 33. A desaparecida pintura do Castelo de Pretzch dedicada aos habitantes da África e o pelicano (Pelecanus rufescens) retratado em um quadro anônimo de Hoflössnitz (pintura 9). 


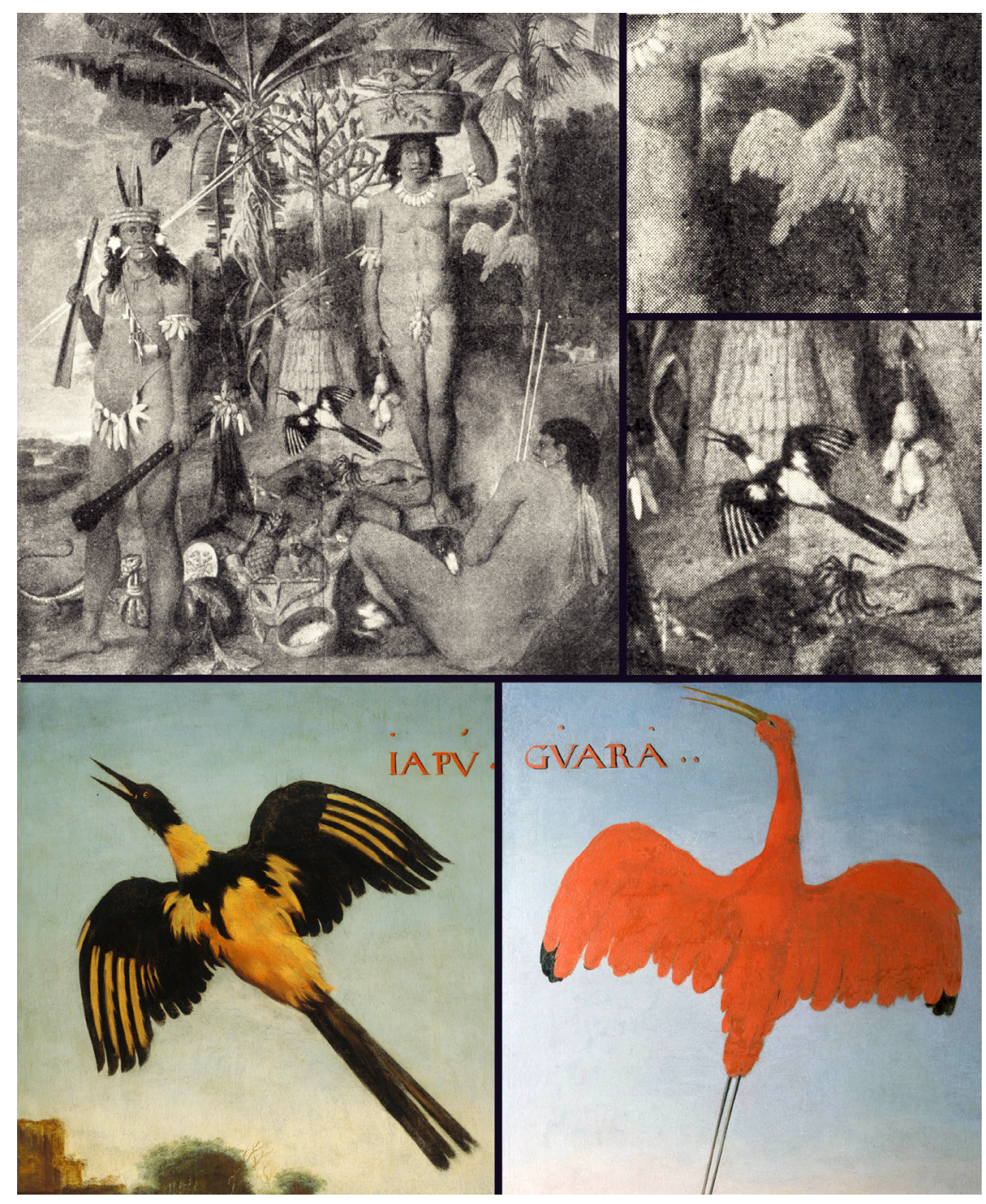

Figura 34. A desaparecida pintura do Castelo de Pretzch dedicada aos índios brasileiros e os quadros do "gúará" (Eudocimus ruber) e do "japú" (Icterus icterus) de Hoflössnitz (pinturas 49 e 68). 


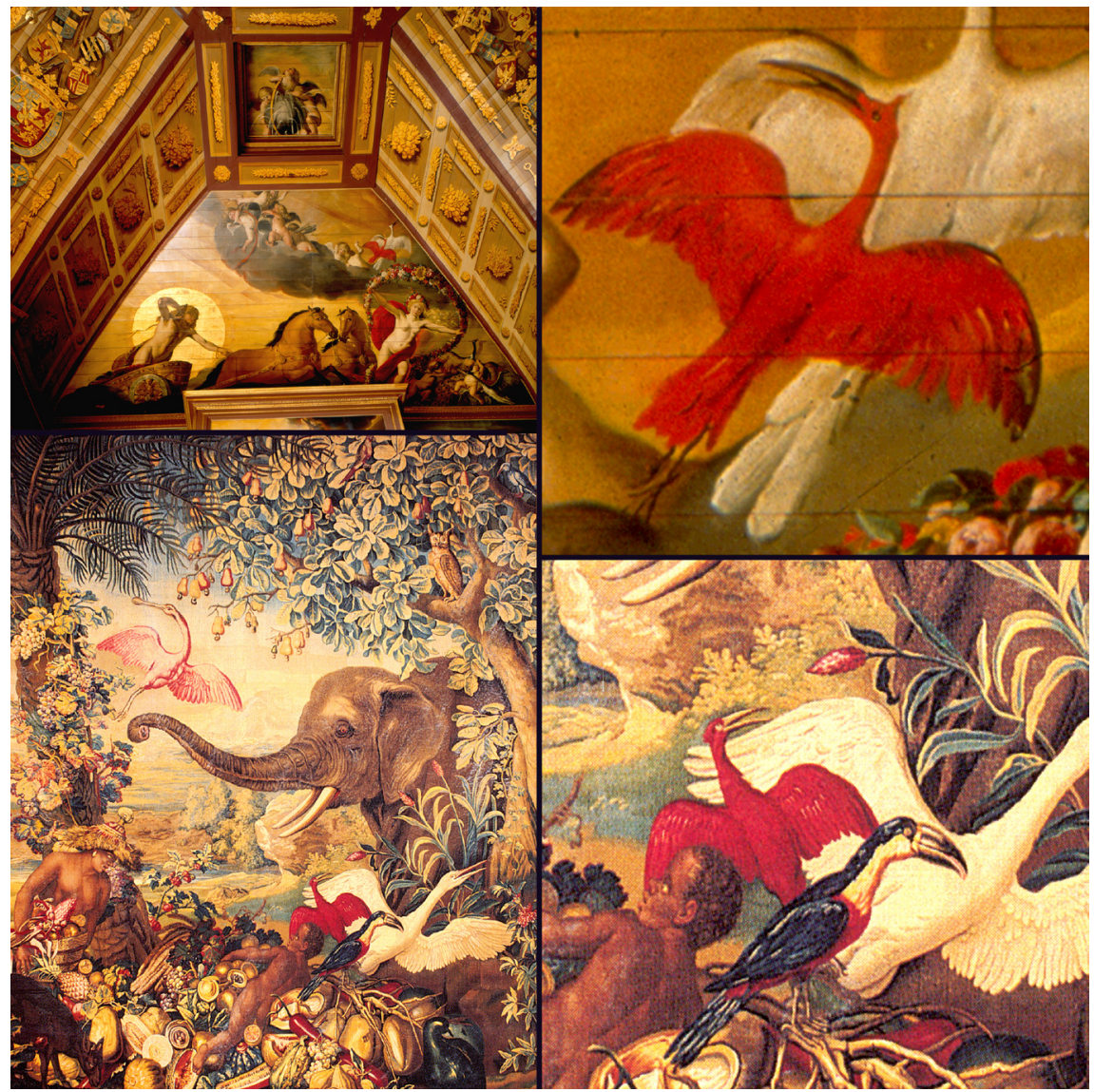

Figura 35. As representações do guará (Eudocimus ruber) existentes no teto da Oranjezaal (Huis ten Bosch, Haia) e no Élephant, uma das tapeçarias pertencentes à famosa série das "Vieilles Indes" dos Gobelins. 